\title{
POLITICAL CONNECTIONS AND INSIDER TRADING
}

\author{
by \\ Thuong Nguyen Harvison \\ Copyright (C) Thuong Harvison 2020 \\ A Dissertation Submitted to the Faculty of the \\ DEPARTMENT OF FINANCE \\ In Partial Fulfillment of the Requirements \\ For the Degree of \\ DOCTOR OF PHILOSOPHY \\ In the Graduate College \\ THE UNIVERSITY OF ARIZONA
}




\section{THE UNIVERSITY OF ARIZONA \\ GRADUATE COLLEGE}

As members of the Dissertation Committee, we certify that we have read the dissertation prepared by: Thuong Nguyen Harvison

titled:

Political Connections and Insider Trading

and recommend that it be accepted as fulfilling the dissertation requirement for the Degree of Doctor of Philosophy.

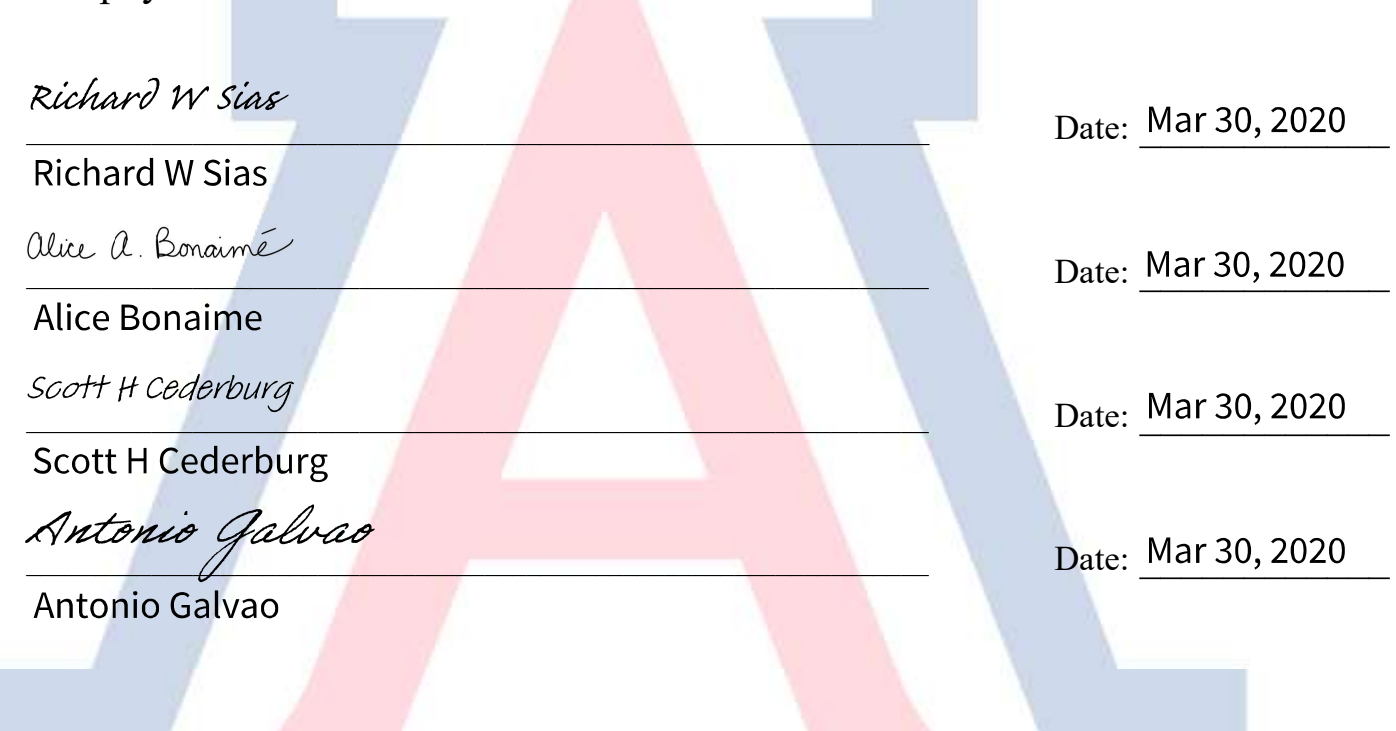

Final approval and acceptance of this dissertation is contingent upon the candidate's submission of the final copies of the dissertation to the Graduate College.

I hereby certify that I have read this dissertation prepared under my direction and recommend that it be accepted as fulfilling the dissertation requirement.

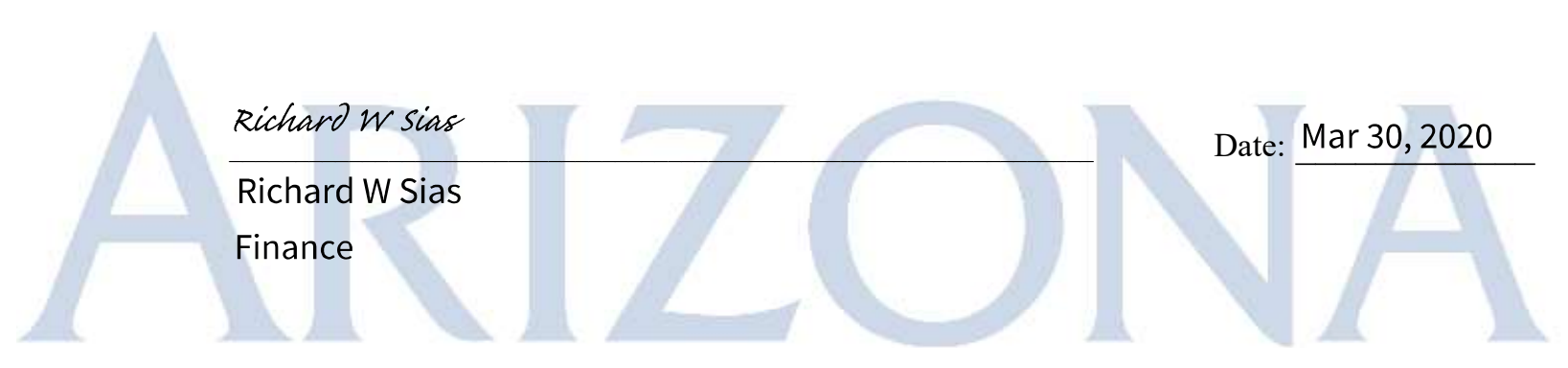




\section{ACKNOWLEDGEMENT}

I am deeply indebted to my dissertation chair, Richard Sias, and my advisor, Alice Bonaimé, for their valuable guidance and encouragement through the program. I am grateful to my dissertation committee members Scott Cederburg, and Antonio Galvao for their feedback and support. I also thank Travis Sapp, Kwabena Boasiako, April Knill, the seminar participants at the University of Arizona, Northern Arizona University, Monmouth University, the 2019 Eastern Finance Association, the 2019 Financial Management Association (FMA), the 2019 FMA doctoral consortium, and the 2020 American Finance Association PhD Student Poster Session for helpful suggestions. 


\section{DEDICATION}

To: Dad, Mom, Michael and Aida.

Thank you for always believing in me and giving me support through this whole journey.

Your unconditional love makes me who I am today. 


\section{TABLE OF CONTENTS}

ABSTRACT

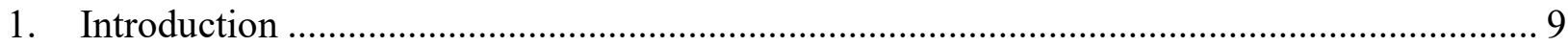

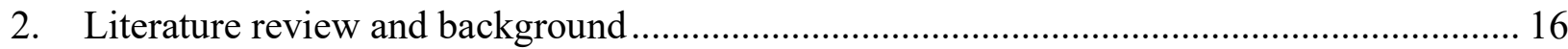

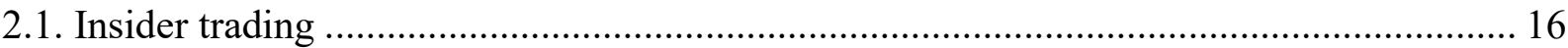

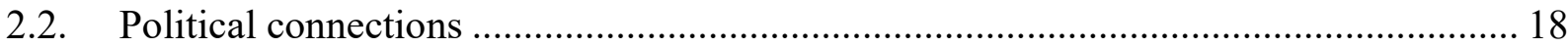

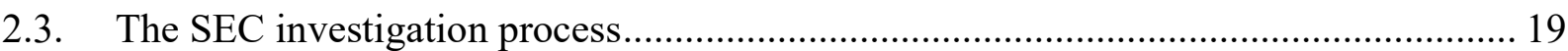

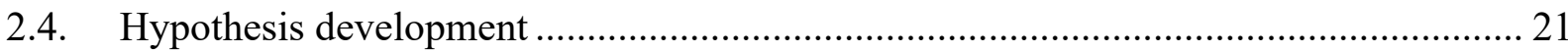

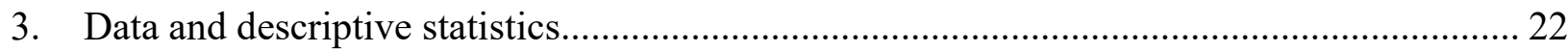

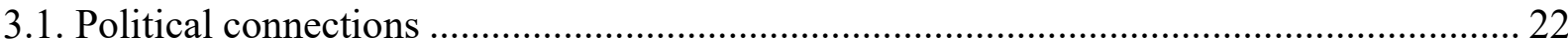

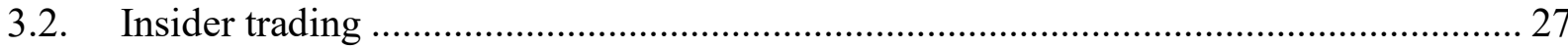

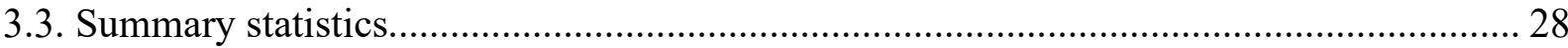

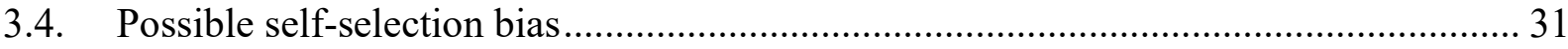

4. The information content of politically connected insider trading .......................................... 32

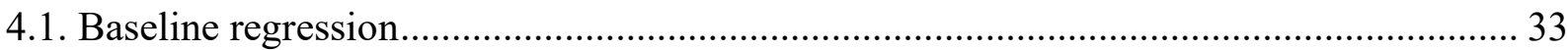

4.2. Which insiders benefit more from political connections?............................................. 35

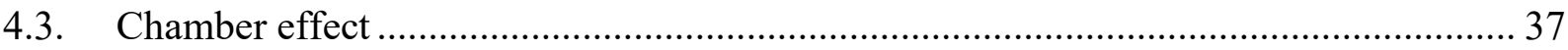

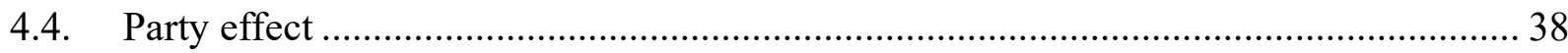

4.5. Robustness check for Performance regressions …………………………................... 40

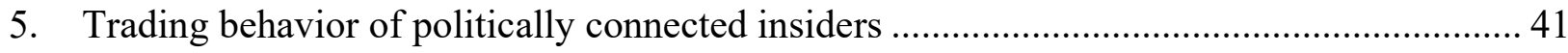

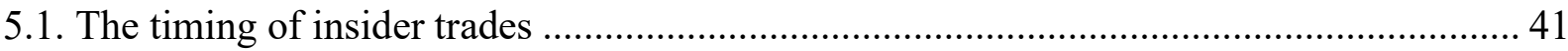

5.2. The timing of insider trading reports ........................................................................... 45

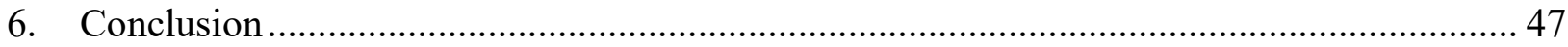

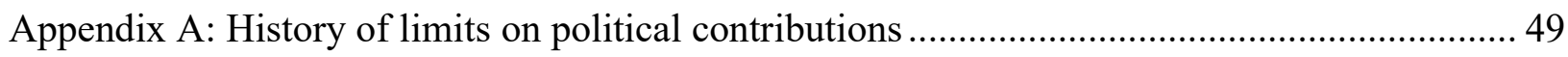




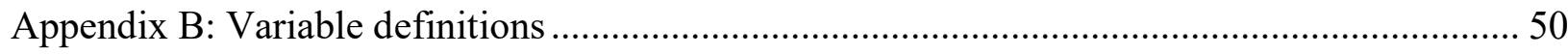

Appendix C: Determinants of firms' political involvement …........................................... 55

Appendix D: Determinants of insiders' political involvement ............................................. 56

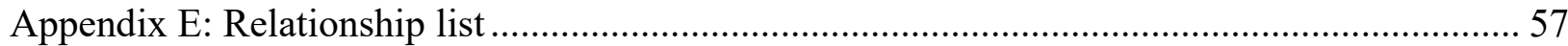

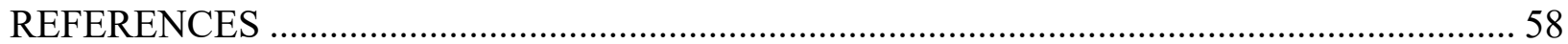




\section{LIST OF TABLES}

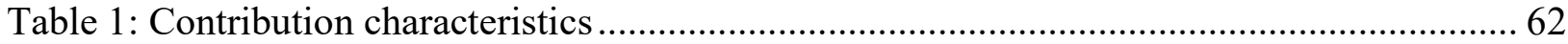

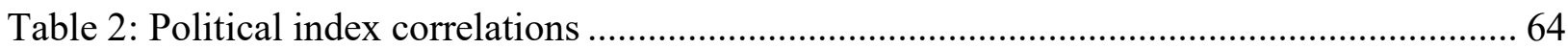

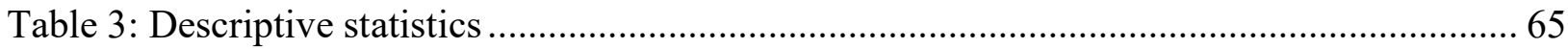

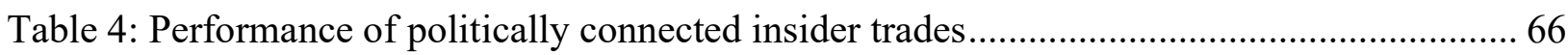

Table 5: Performance of politically connected insider trades for different groups of insiders.... 71

Table 6: Performance regressions for House/Senate political indexes ................................... 72

Table 7: Performance regressions for Democrat/Republican political indexes........................ 73

Table 8: Robustness check for Performance regressions................................................... 76

Table 9: Effects of political connections on insider trading behavior: Days to the closest major

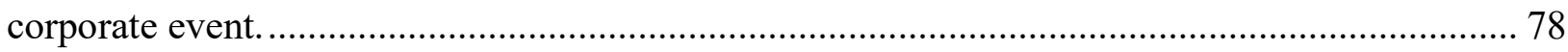

Table 10: Effects of political connections on insider trading behavior: Trading during common

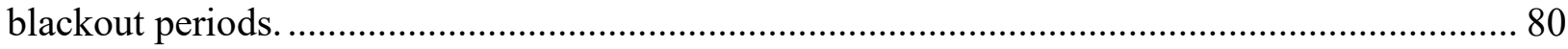

Table 11: Effects of political connections on insider trading behavior: Missing reporting requirement. 


\begin{abstract}
Politically connected insiders, especially senior officers who hold a director position, are more likely sell shares prior to negative abnormal returns. Politically connected insiders are also more likely to engage in other risky behavior: trading prior and closer to major corporate events, trading during periods that overlap with traditional blackout periods, and missing SEC timely reporting requirements. These finding are consistent with insiders perceiving their political connections as protection against SEC enforcement. Consistent with political connections influencing insider trading behavior, the relation is stronger for connections with Senators, who have a greater impact over the SEC than other members of the Congress. Connections with a particular political party have a greater effect on insider trading when the party controls both the House and the Senate.
\end{abstract}




\section{Introduction}

I examine whether insiders' (directors, officers, and large shareholders) political connections influence the aggressiveness of their insider trades. Insider trading on private information is illegal in the US. ${ }^{1}$ The number of insider trading charges by the Securities and Exchange Commission (SEC) has increased in recent years. ${ }^{2}$ The SEC also emphasizes the importance of the detection and prosecution of illegal insider trading activities as one of its enforcement priorities. ${ }^{3}$ However, because the SEC has limited resources, they must decide which cases to investigate (Kedia and Rajgopal, 2011).

Recent work reveals that firms use political connections to gain favorable treatments such as being excluded from an investigation or receiving lower penalties from regulatory agencies (Yu and Yu, 2011, Fulmer, Knill, and Yu, 2012, Correia, 2014). Executives and managers, however, are the people who decide build connections between firms and politicians. I hypothesize that these individuals may seek both corporate and personal benefits. As a result, politically connected corporate insiders will be more willing to engage in "riskier" insider trading practices because they believe their political connections may provide some protection from the SEC. Moreover, because work (Cheng and Lo, 2006, and Rogers, 2008) finds that insider sales are more likely to be investigated by the SEC than insider purchases, I expect the relation between political connections and aggressiveness to primarily occur with insider sales.

\footnotetext{
${ }^{1}$ According to the SEC, "Illegal insider trading refers generally to buying or selling a security, in breach of a fiduciary duty or other relationship of trust and confidence, on the basis of material, nonpublic information about the security. Insider trading violations may also include 'tipping' such information, securities trading by the person 'tipped,' and securities trading by those who misappropriate such information."

${ }^{2}$ See, for example, "SEC Enforcement Actions: Insider Trading Cases"

https://www.sec.gov/spotlight/insidertrading/cases.shtml

${ }^{3}$ See, for example, "Insider Trading” https://www.investor.gov/additional-resources/generalresources/glossary/insider-trading
} 
Following this literature, I use political contributions to proxy for political connections. An insider can build these connections by making donations himself and through the firm. Using the Federal Election Commission (FEC) public dataset and following Cooper, Gulen, and Ovtchinnikov (2010), I calculate eight measures of insiders' political connectedness-four measures based on their firm's political donations and four measures based on their own political donations. These measures take into account the contribution history of each firm and insider as well as the power of the political candidates that they support.

The decision of whether to donate to the political candidates is, however, by choice. My sample is likely to suffer from self-selection bias. To address this problem, I employ the Heckman's (1979) selection model. In the first stage, I estimate the probability of a firm/an insider being involved in politics, i.e., making political contributions, based on different characteristics of the firms, the insiders, and the industries they are operating in. In the second stage, I compute the inverse Mill's ratios for each firm and each insider and include these in all of my regression models to control for the variables that could affect both the decision to make political donations and the tendency to engage in insider trading.

To test the hypothesis that politically connected insiders sell more aggressively to benefit themselves, I first explore the performance of their trades. If they are more likely to sell because of private information, I expect to see lower abnormal returns following their sales. I regress abnormal returns associated with an insider trade on each of the political connection measures and controls. The results from these regressions are consistent with my hypothesis. Sales of insiders with greater long-term political connections generate lower abnormal returns in the 30 trading days following the insider sales. These significant associations are stronger when political connections are measured by the firm's donations (rather than when measured by the insider's personal 
donations). The weaker effects of individual insiders' political connections may be due to the insiders' political contribution patterns. Specifically, firms are more likely to consistently give to politicians relative to more sporadic individual gifts. Consistent with my hypothesis that the effect is driven by insider sales, the positive relation between political connections and subsequent returns to insider trades primarily arises from insider sales - the transactions most exposed to litigation risk.

Among corporate insiders, there are groups (e.g., members of the board of directors and senior officers) who are more likely to possess nonpublic information compared to others (e.g., blockholders and outside associates). If political connections are associated with insider trading on private information, I expect to see the effects of political connections are stronger for directors and senior officers. Moreover, prior literature also argues that insiders holding dual roles is associated with lower corporate governance (Jensen and Meckling, 1976, Fama and Jensen, 1983, Rechner and Dalton, 1991, Pi and Timme, 1993). As a result, I hypothesize that the effects of political connections should be stronger for this group of insiders. Further consistent with my hypothesis, when dissecting into different insider groups, I find that my results hold for directors and senior officers. Moreover, I find that the results are even stronger for insiders who serve as senior officers and directors at the same time, which is consistent with having CEO serving as a director is related to lower corporate governance.

Campaign finance data show that, on average, Senate candidates receive more total dollar contributions and are supported by a larger number of firms and individuals compared to House candidates. If connections come from political contributions, the effects of connections with Senate candidates should be stronger compared to ones with other candidates. To test this hypothesis, I repeat the analysis for the sample split each political index into Senate/House political 
indexes. Consistent with my hypothesis and evidence that the Senate has more SEC and judicial branch control, I find that the relation between political connections, insider trades, and subsequent returns is stronger for Senate candidates than it is for House candidates.

Prior literature shows that when one party has more control over the government, firms supporting this party experience an increase in firm value (Jayachandran, 2006, Cooper, Gulen, and Ovtchinnikov, 2010). Hence, I expect to see connections with one political party have the dominant effect when that party is in control of both chambers. Following the method above, I split each political index into Democrat/Republican political indexes. Consistent with this hypothesis, I find connections with Republican (Democratic) candidates matter more in the periods when the Republican (Democratic) party controls both House and Senate. During periods with control division (e.g., Democrats control the Senate and Republicans control the House), the effects of connections with these two major parties are similar.

To further investigate whether politically connected insiders are more likely to engage in legally risky trading, I examine the relation between insider trading and political connections with three measures of the "legal riskiness" of the trade: trading closer to earnings announcements, trading in sensitive periods (i.e., the most common periods used for blackouts), and failing to meet the SEC timely reporting requirements. Evidence suggests that such trade characteristics are associated with SEC enforcement actions. If politically connected insiders believe they have protection from SEC investigation, then insiders may be more likely to engage in these practices than non-politically connected insiders. 
Most SEC charges arise from insiders' trading just prior to price-sensitive firm events. ${ }^{4} \mathrm{I}$ first examine the relation between political connectedness and how close to a major corporate event an insider is willing to trade. I follow Bessembinder and Zhang (2013) and identify these events as earnings announcements, merger announcements, seasoned equity offerings (SEOs), dividend initiations and repurchase announcements. Because information asymmetry is likely high just prior to price-sensitive events, insider trading right before these events is discouraged and sometimes prohibited by companies. I find negative and statistically significant coefficients on firms' politically connection indices suggesting that connected insiders are more likely to trade closer to major corporate events. The results are consistent with insiders from more politically connected firms engaging in riskier trades. Once again, consistent with my predictions, the results are driven by the firms' level of political connectedness rather than the individual's level of political connectedness.

Many firms have blackout periods during which insiders (and often all employees) cannot trade the company's securities. Although blackout periods vary from firm to firm, most firms close trading in the window of $\mathrm{t}-10$ to $\mathrm{t}+3$ around the releases of earnings announcements (Bettis, Coles, and Lemmon, 2000). I therefore use this window to define "sensitive periods," during which insider trading might increase the risk of drawing SEC attention. Consistent with my hypothesis, I find a positive relation between the likelihood that an insider trade is executed during a sensitive period and both the firms' political connection index and the insider's political connection index.

Next, I investigate if politically connected insiders are less likely to fully comply with reporting requirements. Generally, the SEC has not penalized individuals for missing reporting

\footnotetext{
${ }^{4}$ See, for example, "SEC Enforcement Actions: Insider Trading Cases" https://www.sec.gov/spotlight/insidertrading/cases.shtml
} 
deadlines, but the SEC does emphasize the importance of the filing provisions. ${ }^{5}$ Corporate insiders were required to report their trades before the $10^{\text {th }}$ day of the following calendar month before August 2002 and within 2 trading days after August 2002. I find higher political connection indices for both firms and individual insiders are associated with a higher likelihood of insiders reporting their trades out of the required windows. These findings further support my hypothesis that politically connected corporate insiders are more likely to execute legally risky trades.

In short, I find evidence that politically connected insider's sales are associated with larger abnormal returns. Further consistent with the hypothesis that politically connected insiders are more likely to trade on private information, political connections are associated with more legally aggressive insider trades. My results have several important implications. First, this study contributes to the literature on political connections by showing evidence that political connections may not always benefit shareholders, as at least some insiders appear to exploit firm political donations for personal gains. Moreover, to the extent that insiders personally benefit from corporate connections, shareholders are effectively paying for insider's trading advantage via corporate donations. Critics of insider trading also suggest that if outside investors expect insiders to trade on their private information, they will reduce their investment (Ausubel, 1990) which destroys firm value.

Second, my paper adds to the literature on determinants of insider trading by documenting that the relationships between firms and politicians is associated with the performance of insider trades. My tests suggest that politically connected insiders are more likely to trade on nonpublic information (i.e., their trades garner higher abnormal returns). I also show that political

\footnotetext{
${ }^{5}$ See, for example, "New SEC crackdown on late filings by insiders and major shareholders", Lexology, September 17, 2014 https://www.lexology.com/library/detail.aspx?g=da95770f-2d42-444e-863c-0c5494e07bd2
} 
connections are associated with more legally aggressive insider trading behavior. Connected insiders are more likely to trade in the windows of high information asymmetry, and they are also more likely to delay reporting their trades to hide private information. Finally, although the literature demonstrates that most insiders avoid trading just prior to major corporate events, I find politically connected insiders are still more likely to do so consistent with the hypothesis that they believe that they have more protection from their political connections.

Three related studies investigate political connections and insider trading around a specific event. Specifically, two papers (Akin, Coleman, Fons-Rosen, and Peydró, 2018 and Jagolinzer, Larcker, Ormazabal, and Taylor, 2017) examine insider trading in politically connected banks during the 2008 Financial Crisis and find that trading behavior from politically connected insiders during the period before the Troubled Asset Relief Program (TARP) recipients were announced can predict the stock abnormal returns for the recipients after the announcement. In particular, insider purchases are associated with positive post-announcement performance while insider sales are associated with negative post-announcement performance. In addition, Bourveau, Coulomb, and Sangnier (2016) employ a difference-in-difference design around the 2007 French presidential election and find evidence that insiders of firms with connections to the elected president, through campaign donations or direct friendships, gain larger abnormal returns for the insider trades. These connected insiders are also more likely to violate the French trading requirements. In addition to methodological differences, my study differs from this work by investigating whether politically connected insiders by focusing on insider trading in general rather than a single event or industry. 


\section{Literature review and background}

\subsection{Insider trading}

Trades executed by corporate insiders draw much attention. Media, investors, and regulators often consider these trades signals of firm value since insiders know their business more intimately than others. Insiders may, however, trade in their firms' stock for many other reasons, for example, to rebalance their portfolios, to meet personal liquidity needs, or to manage their taxes (Lakonishok and Lee, 2001; Jenter, 2005). It is important for regulators to discern insider trading motives to adjust the regulatory environment to ensure a fair and efficient market. It is also important for other shareholders to understand insider trading signals since they are affected by this activity.

To test whether corporate insiders trade on private information, numerous papers focus on abnormal stock returns associated with insider trading and show that on average, trades by insiders are profitable (e.g., Lorie and Niederhoffer, 1968; Jaffe, 1974, Rozeff and Zaman, 1988, Bettis, Vickery, and Vickery, 1997, Lakonishok and Lee, 2001). When dissecting individual insider transactions, researchers usually find significantly higher abnormal performance from insider purchases but not sales (Jeng, Metrick, and Zeckhauser, 2003, Piotroski and Roulstone, 2005, Marin and Olivier, 2008, Fernandes and Ferreira, 2009, Ravina and Sapienza, 2010). This evidence is consistent with multiple motives for insider sales, such as liquidity, diversification, and misvaluation, but with misvaluation being a more common motive for insider purchases (Lakonishok and Lee, 2001, Jenter, 2005).

Other papers test for private information in insider trades by examining the timing of insider transactions. Insider trading before price-sensitive news events is hypothesized to signal that insiders trade on their nonpublic information. A major focus of research is the relation between 
insider trading activity and earnings-related events. The results are mixed. While some papers find that insiders do not time their trades around earnings announcements (Elliot, Morse, and Richardson, 1984; Givoly and Palmon, 1985; Park, Jang, and Loeb, 1995), others report a strong relation between insider trading activity and earnings surprises. Penman (1982) finds more net insider purchases in the window of four months before good earnings news and less net insider purchases in the same window before bad earnings news. Elliot, Morse, and Richardson (1984) find similar results using the window of 12 months before earnings announcements. Huddart, Ke, and Petroni (2003) find insider sales increase 3 to 9 quarters prior to bad earnings news. They also posit that the insignificant abnormal selling in 2 quarters just prior to earnings announcements is due to the fear of legal jeopardy. During the period just prior to major price-sensitive events, insiders likely face a higher risk of being charged with illegal information leakage. Consistent with this finding, Huddart, Ke, and Shi (2007) also find that insiders refrain from highly-profitable trades in the 20 days before earnings announcements likely resulting from their desire to avoid regulatory investigation.

Another line of this literature explores the cross-sectional variation in insider trading activity. The relationships between firms and other stakeholders play a role in explaining insider trading activity. Alldredge and Cicero (2015) suggest that when supplier firms have close relationships with their customer firms, insiders from the suppliers are more likely to trade on information gathered from their customers. Moreover, higher corporate governance is found to significantly reduce insider trade profitability (Dai, Fu, Kang, and Lee, 2016). This can be done through having provisions or actions to improve shareholders' benefits, for example, greater monitoring higher outside blockholder ownership (Fidrmuc, Goergen, and Renneboog, 2006), avoiding executives sitting in the auditing committee (Ravina and Sapienza, 2010), assigning a 
general counsel (Jagolinzer, Larcker, and Taylor, 2011), and improving the quality of internal controls (Skaife, Veenman, and Wangerin, 2013). Moreover, since trading decisions are made by insiders, insiders' personal attributes also play a role in predicting insider trading profitability. Hillier, Korczak, and Korczak (2015) find younger insiders, male insiders, and better educated insiders outperform their counterparties and that personal traits explain insider profitability better than firm characteristics do. This finding is consistent with the hypothesis that insiders' individual skills, abilities to acquire and process private information, attitudes to risks and biases (for example, overconfidence and optimism) play a role in insider trading decision and performance.

\subsection{Political connections}

The effect of political connections on firms is a growing topic in finance. There are two competing hypotheses regarding why firms may give to politicians. The first hypothesis claims that relationships with politicians are value-enhancing to firms. Claessens, Feijen, and Laeven (2008) and Cull, Li, Sun, and Xu (2015) show that politically connected firms have more access to bank debt financing. These firms are also more likely to be funded by the government when they face financial troubles (i.e., be bailed out). Faccio, Masulis, and McConnell (2006) and Duchin and Sosyura (2012) document a higher likelihood of bailouts when a politician or a relative of a politician is holding a position in the firm (top officers or large shareholders). Tahoun (2014) finds that firms with stronger relationships with politicians in terms of stock ownership receive more government contracts and these contracts are significantly more profitable to the firms. Consistent with the hypothesis that political connections are valuable, a higher abnormal equity return is found for connected firms (Goldman, Rocholl, and So, 2008; Cooper, Gulen, and Ovtchinnikov, 2010; Chen, Parsley, and Yang, 2010,;Akey, 2015). 
On the other hand, political connections can be reflective of an agency problem between managers and shareholders. That is, political connections may benefit managers rather than shareholders. Consistent with this view, Yu and Yu (2011) report longer class action periods for politically connected firms that are subject to security class action lawsuits. Fulmer, Knill, and $\mathrm{Yu}$ (2012) and Correia (2014) document lower SEC fraud detection and lower penalties when firms make contributions to political candidates. Consistent with this hypothesis, Aggarwal, Meschke, and Wang (2012) document a negative relation between political connections and future stock returns. Unlike prior literature mentioned in the previous paragraph which focuses on short-run event study, they examine long-horizon returns. They argue that using long-term returns is more appropriate to capture the agency motives and how shareholders evaluate the political investments. They also assert that their findings indicate greater agency problems for politically connected firms.

\subsection{The SEC investigation process}

An SEC investigation can be triggered by complaints by investors, any unusual behavior detected during routine inspection of SEC reports, referrals from other government agencies, or information from news and media. The case is assigned to SEC staff. The assigned staff have the discretion over whether to start the investigation. ${ }^{6}$ The investigation usually begins with an informal investigation or a Matter Under Inquiry (MUI). During this stage, the SEC staff has no power to require testimony or issue subpoenas. They collect information based on voluntarily cooperation from involved firms and individuals. This is also a good chance for investigated

\footnotetext{
${ }^{6}$ As pointed out in the SEC Enforcement Manual (2013), "Assigned staffs are encouraged to use their discretion and judgement in making the preliminary determination of whether it is appropriate to open a MUI (Matter Under Inquiry)."
} 
parties to negotiate with the SEC to keep the investigation informal. At the end of this stage, the SEC staff can close the case, recommend an enforcement action, or recommend an order to commence a formal investigation. Most cases terminate during this informal investigation period.

A formal order is issued only by the senior officers of the Enforcement Division. These officers have the discretion over whether to issue one. ${ }^{7}$ Once the formal order is issued, the formal investigation starts. At this stage, the SEC staff has the power to issue subpoenas for documents and compel testimony. Even though the SEC staff still has the option to drop the case, the probability of a formal investigation terminating without any adverse action after this point is lower than in the informal stage. Most of the formal investigations end up with a recommendation to an enforcement action. Since 2010 , about $60 \%$ of the investigations each year result in an enforcement action. ${ }^{8}$

After the recommendation to an enforcement action from the SEC staff, SEC has the discretion to choose to bring the case to the Federal Court or before an independent administrative law judge employed by the commission. ${ }^{9}$ Critics on this matter point out that when being litigated within the SEC, the SEC has much more control over the cases.

\footnotetext{
${ }^{7}$ As pointed out in the SEC Enforcement Manual (2013), "Pursuant to delegated authority, certain senior officers at the Division may, in their discretion, issue a formal order of investigation."

${ }^{8}$ As shown in the 2017 Annual report of the U.S. SEC Division of Enforcement, https://www.sec.gov/files/enforcement-annual-report-2017.pdf

${ }^{9}$ In some particular cases, based on the remedy, the case can only be settled in Federal Court or in an administrative hearing. For example, an emergency asset freeze can only be issued by the Federal Court while suspension, revocation broker-dealer, and investment advisor registrations or barring from the securities industry can only be ordered by an administrative law judge. For more details on how investigation works, see https://www.sec.gov/enforce/howinvestigations-work.html
} 


\subsection{Hypothesis development}

Because SEC has limited resources, they cannot monitor all firms equally (Khademian, 1992). As explained above, the SEC and its staff have discretion over whether to start an investigation, whether to terminate the case at any stage of the investigation, and whether to recommend appropriate penalties. Politicians, on the other hand, can exert their power over SEC activities through different mechanisms. The first mechanism is through the appointment of commissioners as five of the SEC Commissioners are appointed by the President (and confirmed by the Senate). Their terms last five years and staggered so every year, one Commissioner's term ends. ${ }^{10}$ In general, Commissioners and SEC staff may be concerned about their future (Correia, 2014). With the pressure of threats of turnover and current and future career concerns, politicians can encourage Commissioners and staff members to act in accordance with their interests. The second mechanism is by directly interfering with the operation of the SEC. Congress can make the investigation process longer, more intimidating, and more costly to the SEC. Arthur Levitt, the longest-serving Chairman of the SEC from 1993 to 2001, shares his experiences during his years at the SEC in Levitt and Dwyer (2002). According to Levitt, when corporations disagree with the SEC, they go directly to "Capitol Hill," bypassing the SEC. He said: "Soon, I was spending almost all my time deflecting a barrage of phone calls, visits, and letters from House and Senate members".

For commissioners with five-year terms, investigations like this can exhaust their time serving in the SEC, preventing them from impacting policy (Weingast, 1984). Not only does Congress have the ability to control the SEC's activities, they also have the incentive to do so. Connections with corporations, proxied by political contributions, are associated with a higher

\footnotetext{
${ }^{10}$ For a current list of SEC Commissioners, see https://www.sec.gov/Article/about-commissioners.html
} 
probability of re-election (Poole and Romer, 1985; Stratmann, 1995). Thus, politicians may provide protection against the SEC to improve connections with the firms, yielding more donations and maximizing the probability of re-election.

I further propose that corporate insiders, as parts of the firm, also enjoy protection through the firm's connections. Politicians recognize that managers of the firm (i.e., individuals) make corporate decisions. Moreover, individuals can further build their own political relations by contributing to political candidates themselves as individual donors. I investigate whether insiders exploit these connections and engage in legally riskier trading of their firm's stock.

\section{Data and descriptive statistics}

\subsection{Political connections}

Following the literature, I measure political connections by using political contributions. Corporations are prohibited from making direct contributions to federal candidates. However, they can sponsor a political action committee (PAC), known as a "connected PAC" because this PAC is primarily linked with the firm. This PAC can receive money from the firm or other donors and donate to a federal candidate by transferring money to a committee under the candidate's name. ${ }^{11}$ The firm is responsible for all administrative and operating fees of the connected PAC. While the contributions are under the connected PAC's name instead of the firm's name, it is easy to infer that the contributions are associated with the firm. For example, the connected PAC for Paypal is named as "Paypal Inc. Political Action Committee."

\footnotetext{
${ }^{11}$ It is possible, albeit unlikely, that individuals unrelated to the company donate to the corporate PAC.
} 
Data on political contributions are from the FEC contribution dataset from 1981 to 2016 (18 election cycles). Campaign finance law requires federal candidates (candidates running for the House, the Senate, President, and Vice President) to report all parties that give them "hard money" contributions over $\$ 200$ in an election cycle. ${ }^{12}$ (This is in contrast to "soft money," which is noncandidate-specific contributions made to the political parties and is used for "party building" purposes, e.g., administrative expenses, instead of a candidate's campaign.) I collect connected PAC contributions from the "Contributions to candidates" file. This file contains each contribution made by a PAC, party committee, candidate committee, or other federal committee to a candidate committee. To obtain the details on the donors, I merge this file with the "Committee master" file using the donor committee ID. In the "Committee master" file, the FEC classifies all committees that are connected with an organization into six different groups: (1) Corporation, (2) Labor organization, (3) Membership organization, (4) Trade association, (5) Cooperative, (6) Corporation without capital stock. I only focus on transactions from the Corporation group.

Individual contributions are obtained from the "Contributions by individuals" file. This file contains every contribution over $\$ 200$ from an individual to a PAC, party committee, candidate committee, or other federal committee. I measure individual donations by focusing on individual contributions to a candidate committee. To do so I merge this file with the "Committee master" file using the receiving committee ID and only keep the committees with a connected candidate (i.e., if the candidate ID is provided for that committee).

The FEC imposes limits on the amount of contributions a PAC or an individual can make in an election cycle. Since Federal Election Campaign Act (FECA), passed by Congress in 1971,

\footnotetext{
12 Before the Bipartisan Campaign Reform Act in 2002, firms could make "soft money" contributions, which are noncandidate-specific. "Soft money" is donated to political parties for state or local election purposes.
} 
for every election cycle, a PAC can give a maximum amount of $\$ 5,000$ to a candidate during the primary election and $\$ 5,000$ during the general election, totaling $\$ 10,000$ per candidate per election cycle. There is no limit on how much a PAC can contribute, in total, in a cycle. FECA also capped contributions made by individuals at $\$ 2,000$ ( $\$ 1,000$ primary and $\$ 1,000$ general) to each candidate in each election cycle and $\$ 25,000 /$ year (or $\$ 50,000 /$ cycle) in total. These individual limits have been increasing gradually since the Bipartisan Campaign Reform Act in 2002. In 2014, the Supreme Court removed the limits for the total amount of individual contributions and restricted individual contributions per candidate per cycle at $\$ 5,400(\$ 2,700$ primary and $\$ 2,700$ general). More details about limits on contributions from PACs and individuals to federal candidates can be found in Appendix A.

Contribution limits imply that the direct amount donated to a candidate for each firm (insider) is quite low and, perhaps, insufficient to buy candidates' attention. ${ }^{13}$ Thus, other forms of support likely take place. Milyo, Primo, and Groseclose (2010), for example, argue that hard money contributions are used to buy access to the candidates and that these contributions are correlated with other forms of support that firms use to build relationships with politicians. Some firms bypass the contribution limits by having separate connected PACs for their subsidiaries ${ }^{14}$ while others offer the politicians some non-monetary favors, for example, free rides on their company private jets. ${ }^{15}$ Perhaps more important, corporations can give unlimited support to Super

\footnotetext{
${ }^{13}$ For the election cycle 2016, the average funds raised by 10 candidates who raised the least from House and Senate are $\$ 40,636$ and $\$ 2,483,594$ respectively. While these figures for 10 candidates who raised the most from House and Senate are $\$ 8,633,535$ and $\$ 18,835,977$. Election Overview. https://www.opensecrets.org/overview/

${ }^{14}$ See, for example, "Campaign Gifts From Big Insurer Elude the Limit”. The New York Times, September 19, 2006, https://www.nytimes.com/2006/09/19/nyregion/19donate.html

15 See, for example, "Flying Those Corporate-Friendly Skies", Washington Post, October 1, 1998 http://www.washingtonpost.com/wp-srv/politics/campaigns/money/archive/money100798.htm, "Enron's Close Ties to Bush", ABCnews, December 10, 2001 https://abcnews.go.com/Politics/story?id=121269\&page=1, "Politicians are frequent fliers on corporate jets", NBC News, May 10, 2014
} 
PACs that have no official relation with a candidate. Following work in this area, I assume that either corporate or individual giving to a committee formally tied to a candidate is correlated with total giving. For that reason, measures of political connectedness often focus on the contribution history between firms and political candidates rather than dollar values.

To measure the relationship between a firm (or an insider) with political candidates, I use the political connection indices developed by Cooper, Gulen, and Ovtchinnikov (2010) and Correia (2014). The first index, $P I_{i t}{ }^{\text {candidates }}$, for firm (insider) $i$ in an election cycle is defined as

$$
P I_{i t}{ }^{\text {candidates }}=\sum_{j=1}^{J} \text { Candidat }_{j t, t-3}
$$

where Candidate $_{j, t-3}$ is a binary variable that takes a value 1 if firm (insider) $i$ has made contributions to candidate $j$ in any of the past 3 cycles and 0 otherwise. $J$ is the number of candidates supported by firm (insider) $i$. This index measures the total number of supported candidates over the previous 3 cycles. ${ }^{16}$

The second index from Cooper, Gulen, and Ovtchinnikov (2010), $P I_{i t}^{\text {strength }}$ for firm (insider) $i$ in election cycle $t$, measures the strength of the relationships between candidates and contributors and is defined as

$$
P I_{i t}^{\text {strength }}=\sum_{j=1}^{J} \text { Candidate }_{j t, t-3} \times I_{j t} \times \text { Pct }_{j t} \times \text { Rellength }_{j t}
$$

where $I_{j t}$ is an indicator variable equal to 1 if the candidate $j$ was in the office in the election cycle $t$ and equal to 0 otherwise, $P c t_{j t}$ is the percentage of votes received by candidate $j$ in election cycle

http://www.nbcnews.com/id/12616010/ns/nbc nightly news with brian williamsnbc_news investigates/t/politicians-are-frequent-fliers-corporate-jets/\#.W7aVcPZIDcs

${ }^{16}$ I differ from Cooper, Gulen, and Ovtchinnikov (2010) in that I examine donations over three election cycles (while they focus on five calendar years). A firm may support a candidate campaign in an election cycle by clustering their donations in one year of the cycle. 
$t$, and Rellength $h_{\mathrm{t}}$ is the number of cycles that the firm (the insider) has been maintaining an uninterrupted relationship with candidate $j$ until time $t$. This measure accounts for whether the candidates won the election, the percentage of the vote the candidate received, and the length of the uninterrupted relationships. Thus this measure has a larger value when a candidate is more powerful (won by a large majority) and when the insider or firm has a more consistent relationship with the candidate.

The third index from Cooper, Gulen, and Ovtchinnikov (2010), $P I_{i t}{ }^{\text {power }}$ for firm (insider) $i$ in election cycle $t$, measures the power of the candidates by taking into account their rankings within each within House/Senate committee. It is defined as

$$
P I_{i t}{ }^{\text {power }}=\sum_{j=1}^{J} \text { Candidate }_{j t, t-3} \times I_{j t} \times P c t_{j t} \times\left[\sum_{m=1}^{M} \frac{\text { Committee rank }_{m t}}{\text { Median committee rank } k_{m t}}\right]_{j}
$$

where Committee rank r $_{m}$ is the reciprocal of candidate $j$ 's rank on committee $m$ (rank $=1$ for the most important member), and Median committee rank $k_{m}$ is the median rank of members on a given committee $m$ of which candidate $j$ is a member.

My last political index comes from Correia (2017), which captures the number of members of the House and Senate Appropriations, Commerce, Finance and Banking Committees who have a relationship with the firm/the insider through political contributions. These members are in a better position to provide the firm/the insider protection since they have direct control over the SEC operation. $P I_{i t}{ }^{\text {relate }}$ for firm (insider) $i$ in election cycle $t$, is defined as below

$$
P I_{i t}{ }^{\text {relate }}=\sum_{j=1}^{J} \text { Candidate }_{j t, t-3} \times I_{j t} \times \text { Related }_{j t}
$$

where Related $_{j t}$ takes value 1 for politicians serving in the House or Senate Appropriations, Commerce, Finance, and Banking Committees and 0 otherwise. 
To create comprehensive measures of political indices that capture both firms' and insiders' connections, for each insider-firm observation in each election cycle, I compute $P I_{\text {combined }}$ by adding up the values of each political index for firm and for insider. Specifically, for insider i in firm $\mathrm{k}$ in election cycle $\mathrm{t}$,

$$
P I_{\text {combined } i k t}=P I_{\text {firm } k, t}+P I_{\text {insider } i, t}
$$

\subsection{Insider trading}

Insider trading data are from SEC Form 4 filings by Thomson Reuters Filing Database. When an insider executes a transaction involving their company's stock, he or she is required to file Form 4. In this form, the insider must specify the amount of securities purchased or sold and the price per share. Section 16a of the Securities and Exchange Act of 1934 also requires the corporate insiders to report these transactions within 10 days of the next calendar month. On August 27, 2002, the deadline was changed to a two-trading day deadline. The insider trading data are available from 1986, allowing me to have 3 election cycles (1980, 1982, and 1984) to compute the political connection indices before examining insider trading. Therefore, the final insider trading sample period is from November $5^{\text {th }}, 1986$ (the beginning of the 1988 cycle) to November $8^{\text {th }}, 2016$ (the end of the 2016 cycle). I only focus on the open market purchases or sales of common stock (transaction codes "S" and "P", security title "COM"). I follow Cohen, Malloy, and Pomorski (2012) and exclude Table 2, derivative transactions and stock transactions resulting from options exercised, from the sample. I delete trades with cleanse codes "S" and "A" (Agrawal and Nasser, 2012, Rogers, Skinner and Zechman, 2016). I then aggregate all remaining trades per

\footnotetext{
${ }^{17}$ Cleanse code "S" indicates that the security does not meet the collection requirements. Cleanse code " $\mathrm{A}$ " indicates that numerous data elements were missing or invalid and reasonable assumptions could not be made.
} 
insider at the daily level for both purchases and sales (Brochet, 2010; Betzer, Gider, Metzger, Theissen, 2015; Cline and Houston, 2018). For example, if on November $1^{\text {st }}$, an insider had a 100share sale and a 200-share purchase, his/her trading record for Novermber $1^{\text {st }}$ is buying 100 shares.

In October 2000, the SEC enacted Rule 10b5-1, which allows insiders to set up a trading plan that specifies the prices, amount and dates of the trades on a scheduled basis. This rule specifically requires insiders not to own any private information when planning the trades. Therefore, these trades are less likely to be informed, even if they might have some characteristics of the legally risky trades (e.g., close to a major corporate event). I therefore exclude all the trades that are marked as being in a Rule 10b5-1 plan.

Insider trading data are then merged with stock return and price data from the Center for Research in Securities Prices (CRSP), financial data from Compustat, and corporate governance data from Execucomp and Institutional Shareholder Services (ISS). Next, I match political connection indices for firms with insider trading data using firm names. Political connection indices for individual insiders are merged with the main dataset using a fuzzy match algorithm on donor name and insider name. I then hand-clean all matches to make ensure the employer filed with the FEC is similar to firm name from insider trading file. Details on data sources and other

variable constructions for the tests are described in Appendix B. My final sample consists of 815,920 daily insider trades from 106,190 unique insiders of 10,755 unique firms.

\subsection{Summary statistics}

Panel A of Table 1 reports contribution characteristics for the sample of firms with insider trading data for each election cycle from 1980 to 2016. The values in the first three rows of the 
second and fourth columns are missing because data on insider trading are only available from 1986. Overall, about $10 \%$ of the firms ${ }^{18}$ make some political contributions to a candidate committee. The number of candidates supported by a typical firm does not vary much in the 1980 s and 1990s, ranging from 45 to 49 candidates. This number starts to increase in the 2000s and reaches about 60 by 2016 . The average firm contribution per candidate also gradually climbs from $\$ 565$ in 1980 to $\$ 3,110$ in 2016 . The whole distribution of average contribution per candidate per firm also progressively moves to the right with the maximum amount has been at the cap $\$ 10,000$ since 1994. With increases in both the number of candidates supported and the amount spent on each candidate, the average total political expenditure each election cycle, conditional on some giving, for a firm grows nearly 10 times from $\$ 29,000$ to $\$ 235,000$.

Panel B shows contribution statistics for individual insiders. On average, the amount of money an insider contributes to a political candidate is comparable to how much a firm does but the number of candidates supported by an insider is much lower, lying between 2 to 4 candidates, resulting in significantly lower total political expenditures. While in each cycle, at least $99 \%$ of the donating insiders comply with the contribution caps, there are some extreme donations that exceed the limits. The FEC requires the contribution recipients to refund the amount exceeding the limits. However, the data on refunds are not public. On the other hand, donors are rarely

\footnotetext{
${ }^{18}$ From this point, for simplification, I use the term "contributions from a firm" instead of "contributions from a connected PAC of a firm."
} 
punished for a single excess contribution, and, according to the contribution history, these insiders do not continue making excessive donations in multiple cycles. ${ }^{19,} 20$

Table 2 presents the correlation between political connection indices for firms and corporate insiders for the sample of firms and insiders with insider trading data. Consistent with Cooper, Gulen, and Ovtchinnikov (2010), Panel A shows that the four firm political connection

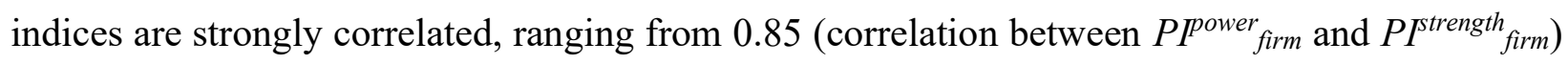
to 0.98 (correlation between $P P^{\text {power }}$ firm and $P P^{\text {relate }}$ firm). Political indices for insiders, demonstrate much lower, but still positive, correlations (Panel B) ranging from 0.51 (correlation between

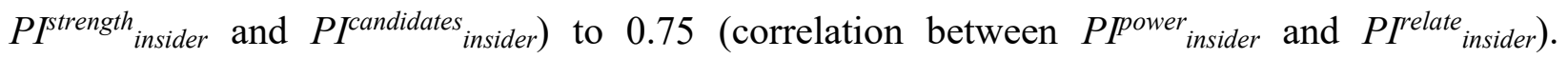
Correlations between political indices for firms and for insiders are positive but very low (Panel C). ${ }^{21}$

Politically connected and non-politically connected firms, on average, could have different characteristics. Table 3 Panel A compares statistics for the sample of firm-years with all zero political indices, both for firms and their insiders (i.e., no political connection) and firm-years with at least one non-zero political index for firms or their insiders (i.e., some political connection). Compared to firms without political connections, firms with some political connections are larger in market capitalization and lower book-to-market ratios. They also have higher institutional

\footnotetext{
${ }^{19}$ In 2018, Rosie O'Donnell, an American comedian, actress, author, and television personality, was reported making $\$ 5,400$ in contributions over the limits to at least five Democratic federal candidates. When asked, she said she often donated and did not pay attention to the limits. She also has a record of making excess contributions to state and city candidates. However, it is unlikely that she will be penalized by the FEC. https://nypost.com/2018/05/05/rosieodonnells-campaign-donations-to-dems-went-over-legal-limit/

${ }^{20}$ See, for example, What Happens When You Break Campaign Finance Law, https://www.huffingtonpost.com/2013/07/22/campaign-contribution-limits_n_3607672.html

${ }^{21}$ Panel C has more observations than Panel B because one insider can be in different firms, which causes more than one insider-firm observation for one insider.
} 
ownership. Their CEOs are more likely to hold a director position, and their boards of directors have a higher proportion of independent directors. The distributions of the variables used in this paper are shown in Appendix C.

\subsection{Possible self-selection bias}

The choice to participate in the political contribution process is endogenous. As shown in Table 1 , only $10 \%$ of firms and less than half of insiders chose to make political donations. The observed sample therefore can suffer from a self-selection bias. To control for this selection bias, I use a two-stage Heckman's (1979) selection model. In the first stage, I estimate the probability of a firm/an insider being involved in the political election process (i.e., making political contribution) using probit regressions. ${ }^{22}$

Overall, bigger firms (in terms of market capitalization, sales, or number of employees), firms with more business segments but fewer geographic segments, firms with higher leverage, firms with lower free cash flows, firms operating in more competitive industry or in regulated industry, firms with more government customers, and firms with higher percentage of unionized employees are more likely to make political contributions. The number of politically connected firms in the industry is also a strong indicator of the likelihood of political involvement. These results are consistent with previous papers that study the determinants of the likelihood of a firm having an active PAC (Masters and Keim, 1985, Grier, Munger and Roberts, 1994, Cooper, Gulen

\footnotetext{
${ }^{22}$ The exclusion restriction of the Heckman's selection model requires that there is at least one independent variable in the first stage not included in the second stage and this variables have no relationship with the error term in the second stage (Certo et al. (2016)). In the first stage for the firms, I include industry level variables that are less likely to affect the insiders' willingness to engage in risky insider trading, for example, the Herfindahl index, number of politically active firms and the percent of unionized employees. These variables are not included in any of the second stage regressions.
} 
and Ovtchinnikov, 2010). For insiders, younger insiders, more experienced insiders (i.e., have been sitting in the position longer), insiders with a bigger network, and insiders who serve on more boards are more likely to make political contributions. The demographics of insiders also play a role in the decision to be politically connected. Males and Americans are the groups with higher probability of political participation. Insiders are also more likely to be politically connected when they have higher compensation and when they have more politically connected co-workers. The detailed results of these first stages are reported in Appendix C for firms and Appendix D for insiders.

In the second stage, I add the inverse Mills ratio calculated from the first stages into the regressions to control for the likelihood of self-selecting into the politically connected group. ${ }^{23}$

\section{The information content of politically connected insider trading}

In this section, I test my first hypothesis. If political connections are associated with more insider trading on private information, I expect a positive relation between the sign of politically connected insider's transactions and the subsequent abnormal return. Specifically, I use the insider trading day as the event date and examine the subsequent 30-trading day excess return. I use market-adjusted return as the measure for excess returns. Excess return for stock $i$ is calculated as

$$
\text { Market }- \text { adjusted return }{ }^{i}(0,30)=\sum_{t=0}^{30}\left(R_{t}^{i}-R_{t}^{m}\right)
$$

where $R_{t}^{i}$ is the daily stock return, $R^{m}{ }_{t}$ is the daily CRSP value-weighted market index,.

\footnotetext{
${ }^{23}$ In some untabulated tables, I run the models (1) without any inverse Mills ratio, (2) with only inverse Mills ratio for the firms, and (3) with only inverse Mills ratio for the insiders and the results hold.
} 


\subsection{Baseline regression}

To control for other factors that may affect insider trade performance, I examine the excess returns associated with insider trades using a regression framework. Specifically, I follow Cohen, Malloy, and Pomorski (2012) and regress the Market-adjusted return $(0,30)$ on the measures of political indices of the firm and the insider with other control variables on a sample of daily insider trades

$$
\begin{aligned}
& \text { Market - adjusted return }(0,30)=\alpha+\beta_{1} P I * \text { Buy }+\beta_{2} \text { PI* Sell }+\gamma_{1} \text { Buy }+ \\
& \gamma_{2} \text { Sell }+\gamma_{3} I M R_{\text {firm }}+\gamma_{4} I M R_{\text {insider }}+\gamma_{5} \text { Past month return }+\gamma_{6} \text { Past year return }+ \\
& \gamma_{7} \operatorname{Ln}(\text { Size })+\gamma_{8} \operatorname{Ln}\left(\text { Book }_{\text {market }}\right)+\varepsilon
\end{aligned}
$$

where $P I$ is a given political index for the firm. Each political index is standardized. As discussed in the previous paragraph, I expect to see different effects of political connections on performance of insider purchases and sales. Therefore, I interact the political index with Buy and Sell where Buy (Sell) takes value of 1 if the transaction is a purchase (sale). $I M R_{\text {firm }}$ and $I M R_{\text {insider }}$ are the inverse Mills ratios from the first stage of Heckman's model. Past month (year) return is the market-adjusted return of the given firm over the prior month (year, excluding the prior month). $\operatorname{Ln}($ Size $)$ is the natural logarithm of market capitalization. Ln(Book_market) is the natural logarithm of ratio of book value of common equity to market capitalization.

Table 4 reports the coefficient estimates for regression (8). Panel A shows the results of a model with only firm political indices and control variables. The coefficients on all interaction terms of firm political indices and Sell are negative and statistically significant at the $1 \%$ level, suggesting that increases in political indices are associated with higher informativeness of insider sales. One standard deviation increases in $\mathrm{PI}^{\text {candidates }}$ firm, $\mathrm{PI}^{\text {strength }}{ }_{\text {firm }}, \mathrm{PI}_{\text {firm, }}^{\text {power }}$, and $\mathrm{PI}^{\text {relate }}{ }_{\text {firm }}$ result in $0.32 \%, 0.25 \%, 0.34 \%$, and $0.32 \%$ decreases, respectively, in the market-adjusted return in the 
$(0,30)$ window for insider sales. However, I find no evidence that political connections are related to the informativeness of insider purchases. Even though all coefficients on interaction terms of firm political indices and Buy are positive, they are not statistically different from zero. My results are similar with the inclusion of month-year fixed effect to control for any time-series variation that might affect returns.

In Panel B, I use political indices for insiders instead of for firms. I find a similar result that insider political connections are significantly related to subsequent 30-trading day excess returns for insider sales while these relationships are positive but insignificant for insider purchases. The magnitudes are, however, smaller than in Panel A. One standard deviation increases in $\mathrm{PI}^{\text {candidates }}{ }_{\text {insider }}, \mathrm{PI}^{\text {strength }}{ }_{\text {insider, }}, \mathrm{PI}_{\text {insider, and } \mathrm{PI}^{\text {power }}{ }_{\text {insider }}}$ result in $0.12 \%, 0.15 \%, 0.10 \%$, and $0.09 \%$ decreases, respectively, in the excess return in the $(0,30)$ window for insider sales. These results also hold when I add month-year fixed effect.

Cheng and Lo (2006) and Rogers (2008) find that the legal risk associated with insider sales is higher than insider purchases. Political connections may improve insider informativeness by providing protection to informed insider trades, thus the effect of political connections is stronger on the performance of insider sales. Consistent with my hypothesis that more informed trading by politically connected insiders is associated with their perception that SEC investigation risk is reduced, I find that political connections are significantly related to abnormal returns for insider sales but not insider purchases.

Panel C of Table 4 shows the coefficient estimates when including both firm and insider political indices. The signs on all variables remain the same as in Panels A and B but the magnitude of interaction terms for insider political indices become slight smaller, which results in weaker $t$ statistics. The higher in magnitudes of interaction terms for firm political indices compared to ones 
for insider political indices also suggest that firm political connections have stronger effects on the performance of insider sales. As shown earlier, individual donors are less likely to maintain a longterm relationship with the candidates. Moreover, firms tend to have connections with politicians through many channels other than "hard money" contributions. The effects of individual insider relationships with the candidates are therefore weaker than ones between the firms and the candidates.

In Panel D of Table 4, I run model (8) with PI $I_{\text {combined }}$ instead of $\mathrm{PI}_{\text {firm }}$ and $\mathrm{PI}_{\text {insider. The signs }}$ and the magnitudes on the main variables confirm that $\mathrm{PI}_{\text {combined }}$ can resemble $\mathrm{PI}_{\text {firm }}$ and $\mathrm{PI}_{\text {insider. }}$ One standard deviation increases in $\mathrm{PI}^{\text {candidates }}$ combined, $\mathrm{PI}^{\text {strength }}$ conbined, $\mathrm{PI}^{\text {power }}$ combined, and $\mathrm{PI}^{\text {relate }}$ combined result in $0.32 \%, 0.26 \%, 0.35 \%$, and $0.32 \%$ decreases, respectively, in the excess return in the $(0,30)$ window for insider sales. The relation between political connections and excess returns remains insignificant for insider purchases.

\subsection{Which insiders benefit more from political connections?}

By definition, corporate insiders include directors, senior officers, above- $10 \%$ equity owner, or anyone who is affiliated with the firm and has access to private information about the firm. However, the effects of political connections on insider trading for these different groups may vary. First, although they are under the same insider trading regulation, the level of corporate nonpublic information that they possess are different. While directors and officers are more likely to know more about corporate events and operations, other employees, while working in the same firm, may not have access to the same information. Large equity owners are even less likely to be informed. Second, the decision to make political donations, even under the firm's name, comes from directors and senior officers. Therefore, they are more likely to benefit from the political 
connections. If my hypothesis holds, I expect to see that the effects of political connections on insider trading performance are higher for the groups of directors and senior officers compared with the rest of the sample.

On the other hand, the board of directors is appointed to monitor the senior officers' behavior. Prior literature (Jensen and Meckling, 1976, Fama and Jensen, 1983, Rechner and Dalton, 1991, Pi and Timme, 1993) argues that there is a higher agency problem when a senior officer also holds a director position. Dual-roled insiders, therefore, are more likely to trade on their private information. If this hypothesis holds, I expect to see the effects on political connections to be even higher for insiders who hold the dual roles.

I then examine which types of insiders are more likely to trade on their private information when they have connections with politicians. In Table 5, I separate the sample into 4 different groups: (1) directors, (2) senior officers, (3) insiders who hold both director and senior officer positions, and (4) others, then run the baseline regression on each of these subsamples. (The details on the position list of each group are provided in Appendix C.) Consistent with my prediction, the coefficients on the interaction term of $\mathrm{PI}_{\text {combined }}$ and Sell are negative and significant for the subsamples of directors, senior officers, and insiders with dual roles while being insignificant in the last subsample. Moreover, the effect of political connections is the strongest in the sample of insiders who serve as both directors and senior officers. My finding is therefore consistent with the hypothesis that dual-roled, politically connected insiders are more likely to trade on their private information.

Overall, firms' political connections are strong predictors of abnormal returns for insider sales but not insider purchases. This finding is consistent with the hypothesis that politically 
connected corporate insiders perform more informed trades because they believe the risk of prosecution is lower due to their political connections.

\subsection{Chamber effect}

On average, Senate candidates receive higher total amounts of contributions than House candidates do. They are also supported by a larger numbers of firms and insiders. ${ }^{24}$ In my sample, on average, a Senate candidate receives about $\$ 818,000$ from 98 firms and 49 insiders while a typical House candidate receive about $\$ 232,000$ from 69 firms and 11 insiders. Therefore, I hypothesize that the political connection effect should be greater for firms contributing to Senate candidates. I split each political index along House/Senate chambers. Specifically, for each political index, I create $\mathrm{PI}_{\text {House }}\left(\mathrm{PI}_{\text {Senate}}\right)$ by multiplying the Candidate variable with a House (Senate) indicator that equals to one if the candidate is affiliated with House (Senate) and zero otherwise. I then rerun regression (6) by replacing each index with the respective $\mathrm{PI}_{\text {House }}$ and PISenate.

However, the correlation between $\mathrm{PI}_{\text {House }}$ and $\mathrm{PI}_{\text {Senate }}$ for each index is high. Putting these two variables into the same regression model may introduce a multicollinearity problem. To address this issue, I follow Cooper, Gulan and Ovtchinnikov (2010) and Corria (2014) and estimate a two-stage regression. In the first stage, I regress each of the House political indexes, $\mathrm{PI}$ House, on its respective Senate political index, $\mathrm{PI}_{\text {Senate, and estimate the residual from this regression, called }}$ $\mathrm{PI}_{\text {House,res. In the second stage, I rerun regression (6) by replacing each PI with } \mathrm{PI}_{\text {House,res }} \text { and } \mathrm{PI}} \mathrm{I}_{\text {Senate. }}$ Results from this second-stage regression is reported in Table 6, Panel A. I also repeat the same

\footnotetext{
${ }^{24}$ See, for example, https://www.opensecrets.org/overview/
} 
process to get $\mathrm{PI}_{\text {Senate, res }}$ and $\mathrm{PI}_{\text {House }}$ and replace in regression (8). Results from this regression is reported in Table 6, Panel B.

Results from Table 6 shows that there is some incremental Senate effect beyond the House effect but insignificant incremental House effect beyond the Senate effect. The coefficients of the interaction between Sell and $\mathrm{PI}_{\text {House,res }}$ are insignificant after controlling for $\mathrm{PI}_{\text {Senate }}(\mathrm{Panel} \mathrm{A})$ but the coefficients on the interaction between Sell and $\mathrm{PI}_{\text {Senate, res }}$ are significant even after controlling for $\mathrm{PI}_{\text {House }}$ (Panel B). Thus, even though political connections with each chamber have effects on the performance of insider sales, connections with Senate candidates show higher impact beyond that provided by connections with House candidates, which is consistent with my hypothesis. This may be because the five SEC commissioners as well as the judges of the judicial branch are confirmed by the Senate, after being selected by the President. The Senate are more likely to have some impact over the SEC investigation and enforcement. The coefficients on the interaction terms between Buy and political indexes for different chambers remain insignificant. Connection with either chamber has little effect on the performance of insider purchases.

\subsection{Party effect}

Jayachandran (2006) finds a significant increase (decrease) in market value of firms contributing to Democrat (Republican) party at the announcement in 2001 that Senator Jim Jeffords switched from Republican Party to Democratic, which transferred control of the Senate from Republican to Democrat. Therefore, I hypothesize that the effect of Democrat/Republican political connections have different effects during times under different party control. To test this hypothesis, I follow the procedure above and analogously calculate $\mathrm{P} \mathrm{I}_{\mathrm{DEM}}\left(\mathrm{PI} \mathrm{R}_{\mathrm{REP}}\right)$ by multiplying the Candidate variable with a DEM (REP) indicator, which is equal to one if the candidate is 
affiliated with the Democratic (Republican) party and zero otherwise for each political index. I also follow the two-stage regression and estimate PIDEM, res and PIREP, res. I then rerun model (6) replacing each political index with new Democratic/Republican political indexes for the whole sample. I then divide the whole sample into three subsamples: (1) when Republicans control both the House and the Senate, (2) when Republicans control the House and Democrats control the Senate, and (3) when Democrats control both the House and the Senate. ${ }^{25}$ I perform the same test on each of the subsamples.

Panel A of Table 7 presents the results of the regression model (6) during the periods when Republicans control both the House and the Senate. During these periods, there is an incremental Republican effect and an insignificant incremental Democrat effect. The coefficients on the interactions between Sell and PIREP, res are significant after controlling for PIDEM (Panel A1) but the coefficients on the interactions between Sell and PIDEM, res are insignificant after controlling for PIREP (Panel A2). Overall, connections with Republican candidates have effects on insider trade performance that are above and beyond ones with Democratic candidates. Conversely, in Panel C of Table 7, when Democrats control both the House and the Senate, I find a strong incremental Democrat effect and little incremental Republican effect. The coefficients on the interactions

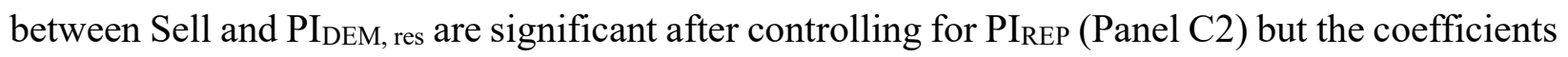
on the interactions between Sell and $\mathrm{PI}_{\mathrm{REP}}$, res are insignificant after controlling for PI $\mathrm{DEM}_{\mathrm{DE}}$ (Panel C1). However, as shown in Panel B, when there is a division of control (e.g., Republicans control the House and Democrats control the Senate), there is no incremental effect for either party. The coefficients on $\mathrm{PI}_{\mathrm{REP}}$, res and $\mathrm{PI} \mathrm{I}_{\mathrm{DEM}}$, res are insignificant when controlling for $\mathrm{PI}_{\mathrm{DEM}}$ and $\mathrm{PI} \mathrm{I}_{\mathrm{REP}}$,

\footnotetext{
25 Throughout my whole sample of election cycle 1988 to election cycle 2016, there is no time with Democrat controlling House with Republican controlling Senate.
} 
respectively. I find no evidence that Democratic or Republican political connections are associated with higher performance for insider purchases across different subsamples.

Overall, connections with both parties are associated with higher performance for insider trades, and connections to the party in control have larger effects on the performance of insider trades. When there is a division of control, it appears that connections to both parties have approximately the same impact.

\subsection{Robustness check for Performance regressions}

Corporate insiders, especially ones with long-lived information advantage, tend to spread their trades within a few days then report them together in one filing to hide their private information from the market (Biggerstaff, Cicero, and Wintoki, 2015). Therefore, one might argue that trades in the same report contain the same information. By including all daily trades, signals from the informed trade may be duplicated, which has the potential to bias the test results. To ensure spreading insider trades does not drive my results, I aggregate all trades within one report and treat each report as one observation then rerun the baseline regression (6) on this new sample.

I report the results for the robustness test in Table 8 . I use the date of the first trade as the report's transaction date in Panel A and the date of the last trade in Panel B. The coefficients on the main variables do not change significantly compared to ones in the baseline regression. There is a significantly negative relation between politically connections and the subsequent 30 -day abnormal return following insider sales while this relation for insider purchases is insignificant. In short, my results hold after adjusting for multiple trades in an insider trading report. 


\section{Trading behavior of politically connected insiders}

This section examines whether politically connected insiders are more likely to engage in legally riskier insider trading. I have two sets of tests. First, I examine the timing of insider trades. Specifically, I test if (a) politically connected insiders are more likely to trade closer to major corporate event dates that non-politically connected insiders and (b) if politically connected insiders are more likely to trade in traditional blackout periods than non-politically connected insiders. Second, I examine timing of insider trading reports. Specifically, I test whether politically connected insiders are more likely to report their trades later than the SEC deadlines.

\subsection{The timing of insider trades}

The vast majority of SEC charges for insider trading involves the leakage of nonpublic information right before a price-sensitive events. ${ }^{26}$ Thus, I first test if politically connected insiders are more likely to trade closer to a major corporate event.

I begin by following Bessembinder and Zhang (2013) and identifying the set of events that can potentially cause price fluctuations during the period of 1986 to 2016 . These events include earnings announcements, merger announcements, SEOs, dividend initiations and repurchase announcements. The list of earning announcements dates are form Compustat quarterly. I collect mergers and acquisitions (M\&As) completed by US public companies using Thomson Financial's SDC database. I follow Betton, Eckbo, and Thorburn (2008) and include only deals in the form of merger (deal form $M$ ), acquisition of major interest (AM), acquisition of remaining interest (AR), or acquisition of partial interest (AP). The deals also must have the acquirer owning less than 50\% of the target prior to the deal and seeking to hold more than $50 \%$ after the deal. To exclude small deals, which are less likely to have material impact, I exclude all deals with transaction value below

\footnotetext{
${ }^{26}$ SEC Enforcement Actions: Insider Trading Cases https://www.sec.gov/spotlight/insidertrading/cases.shtml
} 
$\$ 5$ million. For the SEOs, I collect all offerings from SDC database which are not American Depository Receipts, Global Depository Receipts, or unit offerings. The list of repurchase announcements are also from SDC database. To identify the dividend initiations, I follow Michaely, Thaler, and Womack (1995) and mark the date of the first cash dividend in the sample or the first dividend in three years for common stocks (share code 10 or 11) that are listed on major stock exchanges and have been included in the CRSP database.

I then compute, for every insider trade, the number of days prior to the next event date. I therefore test whether politically connected insiders are more likely to have the same trading patterns as the charged insider trading cases from the SEC. Specifically, I run the following OLS regression on the sample of all insider trades:

$$
\begin{array}{r}
\text { Days to event }=\alpha+\beta_{1} P I_{\text {combined }} * \text { Buy }+\beta_{2} P I_{\text {combined }} * \text { Sell }+\gamma_{1} \text { Buy }+ \\
\gamma_{2} \text { Sell }+\gamma_{3} I M R_{\text {firm }}+\gamma_{4} I M R_{\text {insider }}+\gamma_{5} \operatorname{Ln}(\text { Size })+\gamma_{6} \text { Institutional Ownership }+ \\
\gamma_{7} \text { Abs }(\text { Announcement Return })+\gamma_{8} \text { CEO duality }+\gamma_{9} \text { Board independence }+\varepsilon
\end{array}
$$

where the dependent variable Days to event is the number of days between the insider's trade and the subsequent major corporate event date. I add Size, Institutional Ownership, and the absolute value of Announcement Return to control for information asymmetry. A larger firm or a firm with higher institutional ownership should have lower level of information asymmetry (Stoll, 1978, Chari, Jagannathan, and Ofer, 1988, Brennan and Subrahmanyam, 1995) while a large absolute value of announcement return is associated with higher information asymmetry (Yohn, 1998). Since (legally) risky insider trading involves trading on the private information, I expect to see this behavior more in firms with higher information asymmetry. Moreover, the literature on the effects of corporate governance shows that better corporate governance deters risky insider trading 
patterns (see, for example, Fidrmuc, Goergen, and Renneboog, 2006, Ravina and Sapienza, 2010, Jagolinzer, Larcker, and Taylor, 2011, Skaife, Veenman, and Wangerin, 2013, and Dai, Fu, Kang, and Lee, 2016). For 2 firms with the same political indexes, insiders from the firm with better corporate governance might be less likely to engage in aggressive trading. Therefore, I control for corporate governance by adding $C E O$ duality and Board independence as independent variables. ${ }^{27}$ A firm whose CEO also sits on the board of directors has worse corporate governance while a higher proportion of independent directors in the board of directors implies better corporate governance (Brickley, Coles, and Terry, 1994, Brickley, Coles, and Jarrell, 1997, Gillan, 2006).

Table 9 reports the coefficient estimates for the OLS regression of model (7) with the number of days to the next corporate event as the dependent variable. In the specifications (1), (3), (5), and (7), I do not include controls for information asymmetry and corporate governance. The coefficients on $\mathrm{PI}^{\text {candidates }}$ combined, $\mathrm{PI}^{\text {strength }}$ combined, $\mathrm{PI}^{\text {power }}$ combined, and $\mathrm{PI}^{\text {relate }}$ combined are negative and statistically significant for both purchases and sales, suggesting that, on average, political connections are associated with the insider trading, both buying and selling, closer to the next major event. A one standard deviation increase in firm political indices results in a 0.44 to 0.55 decrease in number of days from transaction date to the next major event for insider purchases and a 0.65 to 0.68 decrease for insider sales. Political indices for the insider also have a significant effect on how close his/her sales are to the next price-sensitive event. My results hold even after including variables controlling for information asymmetry and corporate governance (specifications (2), (4), (6), and (8)). Politically connected insiders are more likely to trade closer to the next major corporate event.

\footnotetext{
${ }^{27}$ The data on CEO duality are only available after 1992 and data on Board independence are available after 1996. Hence, in the model including them, I lose some observations.
} 
My next timing test exploits the fact that many firms impose blackout windows, during which most of the employees, including corporate insiders, are not allowed to trade company stock. A survey by Bettis, Coles and Lemmon (2000) shows that $92 \%$ of responding firms have some policies restricting insider trading and $78 \%$ have detailed blackout periods. The most common blackout period (see Bettis, Coles, and Lemmon, 2000) is the window from day -10 to +3 around the earnings announcements. Thus, I define this window as a period where insider trading may be more likely to attract attention from regulators. Therefore, while there is some overlap with the previous tests (e.g., trading just prior to earnings will imply a short period until earnings announcement and be in the traditional blackout period) I examine differences in politically connected and non-politically connected insiders willingness to trade in the -10 to +3 window. Specifically, I estimate the following logit regression:

$$
\begin{array}{r}
\text { Sensitive trading }=\beta_{1} P I_{\text {combined }} * \text { Buy }+\beta_{2} P I_{\text {combined }} * \text { Sell }+\gamma_{1} \text { Buy }+ \\
\gamma_{2} \text { Sell }+\gamma_{3} I M R_{\text {firm }}+\gamma_{4} I M R_{\text {insider }}+\gamma_{5} \operatorname{Ln}(\text { Size })+\gamma_{6} \text { Institutional Ownership }+ \\
\left.\gamma_{7} \text { Abs (Announcement Return }\right)+\gamma_{8} \text { CEO duality }+\gamma_{9} \text { Board independence }+\varepsilon
\end{array}
$$

where the dependent variable Sensitive trading is an indicator variables that takes value one if a trade is executed in the $t-10$ to $t+3$ trading day window around an earnings announcement. All other variables are the same as described in model (8).

Table10 reports the coefficient estimates (Panel A) and marginal effects (Panel B) for the logit model (8). The coefficients on political indices for firms are all positive and significant for both purchases and sales. The higher the level of connections between the firms and politicians, the more likely that the insider trades during the windows that can be risky to trade. A one standard 
deviation increase in each of the firm political indices leads to an increase of $0.12 \%$ to $0.23 \%^{28}$ in probability of a purchase and an increase of $0.24 \%$ to $0.34 \%$ in probability of a sale occurring in the sensitive window centered on its mean. I also find positive and significant coefficients for all insider political indices for sales. Even after controlling for the political connections of the firms, insiders with implicit political connections are more likely to sell in the $(\mathrm{t}-10, \mathrm{t}+3)$ windows around an earnings announcement. My results are robust after including variables that help capture variation in information asymmetry and corporate governance.

\subsection{The timing of insider trading reports}

Before August 2002, the SEC required corporate insiders to report their trades no later than the $10^{\text {th }}$ day of the next calendar month. This requirement was shortened to two trading days with the introduction of the Sarbanes-Oxley Act ('SOX'). In the past, even when the SEC noticed violations of this disclosure requirement, there was rarely any serious legal consequence for disobeying insiders. However, with the increase in the incidents of late filings, the SEC has highlighted the importance of the filing provisions. In September 2014, the SEC filed charges against 33 corporate insiders with the total penalty of $\$ 2.6$ million. ${ }^{29}$ This is an action from the SEC to emphasize that they would start vigorously monitoring these types of violations. ${ }^{30}$

On the other hand, research has found that corporate insiders purposefully delay reporting their trades to hide their nonpublic information. In this way, they can extract rents using this private

\footnotetext{
${ }^{28}$ All political indices are standardized to mean 0 and standard deviation 1 . Therefore, the marginal effects show the changes in dependent variable with one-standard deviation change in political indices.

${ }^{29}$ See, for example, "SEC Targets Timing of Insiders' Trade Notices", The Wall Street Journal, September 10, 2014 https://www.wsj.com/articles/sec-reaches-settlements-with-insiders-over-late-filings-1410367803

${ }^{30}$ See, for example, "The SEC to Insiders: When We Say File Your Section 16(a) Forms, We Mean It". Woodruff Sawyer, October 15, 2014 https://woodruffsawyer.com/do-notebook/section-16a/
} 
information before it is priced by the market (Cheng, Nagar and Rajan, 2007). Consistent with this hypothesis, Cline and Houston (2018) find that trades in violation earn significant abnormal returns in the window from trading date to reporting date. Therefore, if politically connected insiders trade on their private information, I expect connected insiders to be more likely to purposefully delay reporting their trades. I examine the likelihood of politically connected insiders violating trading reporting requirements from the SEC. A trade report is considered late if the day the SEC receives the report is after the $10^{\text {th }}$ day of the next calendar month from the transaction day before August 2002 and if the number of trading days between transaction day and the day the SEC receives the report is more than 2 days after August 2002. Consistent with Cline and Houston (2018), 17.76\% of the trades in my sample are reported after the SEC deadline. Specifically, I estimate the following logit regression.

$$
\begin{array}{r}
\text { Late reporting }=\alpha+\beta_{1} P I_{\text {combined }} * \text { Buy }+\beta_{2} P I_{\text {combined }} * \text { Sell }+\gamma_{1} \text { Buy }+ \\
\gamma_{2} \text { Sell }+\gamma_{3} I M R_{\text {firm }}+\gamma_{4} I M R_{\text {insider }}+\gamma_{5} \operatorname{Ln}(\text { Size })+\gamma_{6} \text { Institutional Ownership }+ \\
\left.\gamma_{7} \text { Abs (Announcement Return }\right)+\gamma_{8} \text { CEO duality }+\gamma_{9} \text { Board independence }+\varepsilon
\end{array}
$$

where the dependent variable Late reporting is an indicator variable that takes value one if the inside reports a trade after the reporting deadline, and takes value zero otherwise.

Table 11 reports the coefficient estimates for the logit model of whether an insider trade is reported late on political connection indices. Consistent with the findings in the timing tests, I find positive and significant coefficients for all political connection indices on both purchases and sales. Insiders are more likely to report their trades late when they have connections with the politicians. A one standard deviation increase in each of comprehensive political connection indices is 
associated with an increase of $1.89 \%$ to $2.10 \%$ in probability of a sale and an increase of $0.66 \%$ to $1.15 \%$ in probability of a purchase being reported after the deadline, centered around its mean. Again, results from this test are consistent with the hypothesis that political connections have more impact on insider sales since these trades are associated with higher litigation risk. These findings also hold when I control for information asymmetry and corporate governance.

In short, the results in this section provide evidence supporting my hypothesis that politically connected insiders trade more aggressively. Politically connected insiders are more likely to profit themselves by performing trades that would normally call attention from the SEC. They trade more closely to earnings announcements, they are more likely to trade in the most common blackout period, and they are less likely to file timely reports.

\section{Conclusion}

I hypothesize that politically connected insiders are more likely to engage in legally risky insider trading because they believe their political relationships will help protect them from SEC investigation and prosecution. Consistent with my hypothesis, political connections are positively related to the trade performance of connected insiders, especially senior officers who also hold a director position. Furthermore, I find this association is driven by insider sales consistent with the view that insider sales are associated with higher legal risk.

Among all connections with politicians, connections with Senate candidates have a greater effect on insider trading behavior than ones with House candidates. Senators have more control over the SEC since they are more involved in appointing the SEC commissioners. Connections 
with Republican (Democratic) candidates matter more when the Republican (Democratic) Party has control over both the House and the Senate.

Further tests provide evidence that politically connected insiders trade more riskily. They trade closer to the major corporate events, trade during the most common blackout windows, and are more likely to miss the trading reporting requirements. These behaviors are shown to trigger SEC insider trading investigations. 


\section{Appendix A: History of limits on political contributions}

This appendix provides a brief overview on changes on limits on political contributions over time. While the details on these limits are rather extensive, in this appendix, I focus on provisions related on individual and corporate contributions.

The Federal Election Campaign (FECA), passed by the Congress in 1971, was the first set of rules on public funding of federal elections. Besides setting disclosure requirements for all candidates and political parties, it establishes the strict limits on contributions made by individuals and specific interest groups to candidates, parties and political action committees (PACs). Corporations are prohibited from making direct contributions to federal candidates. However, they can sponsor a connected PAC and this PAC can give money to the candidate committees. According to this Act, for each two-year election cycle, each PAC can contribute up to $\$ 5,000$ during a primary election and $\$ 5,000$ during a general election to a candidate, which makes $\$ 10,000$ per election cycle per candidate. Individuals are allowed to make up $\$ 1,000$ per candidate in each election round, adding up to $\$ 2,000$ per candidate per election cycle. FECA also put a limit of $\$ 25,000 /$ year on the total amount of contributions that an individual can make. No limit was set on total amount of contributions made by a PAC. Individuals and PACs, however, can contribute unlimited amounts during elections in "soft money", which are contributions not associated with the candidate campaign, to political parties. "Soft money" can be used for party building or administrative expenses.

The Bipartisan Campaign Reform Act (BCRA) was passed in 2002 with significant changes in the campaign finance system in the US. Two major changes regarding contribution limits introduced the BRCA are the ban of all "soft money" contributions and the increases in limits for individual contributions to federal candidates. The details on changes on these limits are shown in the table below. There was no change on limits on contributions made by PACs.

In 2014, the Supreme Court removed the limit on total amount of political contributions made by individuals. Individuals now can give an unlimited amount in total candidates, PACs and political parties combined. Contribution limits for PACs remained unchanged.

\begin{tabular}{clccc}
\hline \multirow{2}{*}{$\begin{array}{c}\text { Election } \\
\text { cycle }\end{array}$} & \multicolumn{2}{c}{ From individual donors } & \multicolumn{2}{c}{ From PACs } \\
\cline { 2 - 5 } To candidate & Aggregate total & To candidate & Aggregate total \\
\hline Up to 2002 & $\$ 1,000 /$ election & $\$ 25,000 /$ year & $\$ 5,000 /$ election & No limit \\
2004 & $\$ 2,000 /$ election & $\$ 37,500 /$ cycle & $\$ 5,000 /$ election & No limit \\
2006 & $\$ 2,100 /$ election & $\$ 40,000 /$ cycle & $\$ 5,000 /$ election & No limit \\
2008 & $\$ 2,300 /$ election & $\$ 42,700 /$ cycle & $\$ 5,000 /$ election & No limit \\
2010 & $\$ 2,400 /$ election & $\$ 45,600 /$ cycle & $\$ 5,000 /$ election & No limit \\
2012 & $\$ 2,500 /$ election & $\$ 46,200 /$ cycle & $\$ 5,000 /$ election & No limit \\
2014 & $\$ 2,600 /$ election & $\$ 46,800 /$ cycle & $\$ 5,000 /$ election & No limit \\
2016 & $\$ 2,700 /$ election & No limit & $\$ 5,000 /$ election & No limit \\
\hline
\end{tabular}

Note: Primary and general elections count as separate elections. 


\section{Appendix B: Variable definitions}

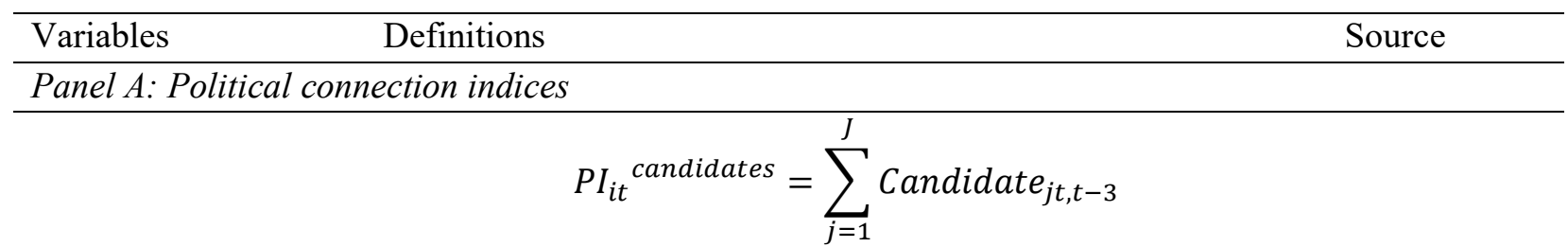

$\mathrm{PI}^{\text {candidates }}$

where Candidate $_{\mathrm{jt}, \mathrm{t}-3}$ is a binary variable, takes value 1 if firm

FEC (insider) $\mathrm{i}$ has made contributions to candidate $\mathrm{j}$ over the past 3 cycles and 0 otherwise. $\mathrm{J}$ is the number of candidates supported by firm (insider) $i$

$$
\begin{aligned}
P I_{i t}{ }^{\text {strength }}= & \sum_{\substack{j=1 \\
\text { Landidate } \\
j t, t-3}}^{J} \times I_{j t} \times \text { Pct }_{j t} \\
& \times \text { Rellength }_{j t}
\end{aligned}
$$

where Candidate $_{\mathrm{jt}, \mathrm{t}-\mathrm{3}}$ is a binary variable, takes value 1 if the

$\mathrm{PI}^{\text {strength }}$ firm (the insider) has made contributions to candidate $\mathrm{j}$ over the past 3 cycles and 0 otherwise, $J$ is the number of candidates

FEC supported by firm (insider) $i, I_{i t}$ is an indicator variable equal to 1 if the candidate won the election cycle $t$ and equal to 0 otherwise, Pct $_{\mathrm{jt}}$ is the percentage of votes received by candidate $\mathrm{j}$ in election cycle $t$, Rellength $\mathrm{j}_{\mathrm{j}}$ is the number of cycles that the firm (the insider) has been maintaining an uninterrupted relationship with candidate $\mathrm{j}$ until time $\mathrm{t}$

$$
\begin{aligned}
& P I_{i t}{ }^{\text {power }}=\sum_{j=1}^{J} \text { Candidate }_{j t, t-3} \times I_{j t} \times P c t_{j t} \\
& \times\left[\sum_{m=1}^{M} \frac{\text { Committee rank }_{m t}}{\text { Median committee rank } k_{m t}}\right]_{j}
\end{aligned}
$$

$\mathrm{PI}^{\text {power }}$

where Candidate $_{j, t-3}$ is a binary variable, takes a value of 1 if the firm (the insider) has made contributions to candidate $j$ in each of the past 3 cycles and 0 otherwise, $J$ is the number of candidates supported by firm (insider) $i, I_{j t}$ is an indicator variable equal to 1 if the candidate $j$ was in the office in the election cycle $t$ and equal to 0 otherwise, $P c t_{j t}$ is the percentage of votes received by candidate $j$ in election cycle $t$, Committee rank $_{m t}$ is the reciprocal of candidate $j$ 's rank on committee $m$ (rank $=1$ for the most important member), and Median 
committee rank $_{m t}$ is the median rank of members on a given committee $m$ of which candidate $j$ is a member

$$
P I_{i t}^{\text {relate }}=\sum_{j=1}^{J} \text { Candidate }_{j t, t-3} \times I_{j t} \times \text { Related }_{j t}
$$

where Candidate $_{j, t-3-3}$ is a binary variable, takes a value of 1 if the firm (the insider) has made contributions to candidate $j$ in

$\mathrm{PI}^{\text {relate }}$ each of the past 3 cycles and 0 otherwise, $J$ is the number of candidates supported by firm (insider) $i, I_{j t}$ is an indicator variable equal to 1 if the candidate $j$ was in the office in the election cycle $t$ and equal to 0 otherwise, and Related ${ }_{j t}$ takes value 1 for politicians serving in the House or Senate Appropriations, Commerce, Finance and Banking Committees and 0 otherwise

\begin{tabular}{|c|c|c|}
\hline \multicolumn{3}{|c|}{ Panel B: Control variables } \\
\hline $\mathrm{IMR}_{\text {firm }}$ & $\begin{array}{l}\text { The inverse Mills ratio from Heckman's (1979) selection } \\
\text { model, estimated using the results from Probit model for firm's } \\
\text { political involvement in Appendix C }\end{array}$ & \\
\hline $\mathrm{IMR}_{\text {insider }}$ & $\begin{array}{l}\text { The inverse Mills ratio from Heckman's (1979) selection } \\
\text { model, estimated using the results from Probit model for } \\
\text { insider's political involvement in Appendix D }\end{array}$ & \\
\hline $\operatorname{Ln}($ Size $)$ & $\begin{array}{l}\text { Natural logarithm of the market capitalization, using data on } \\
\text { transaction date }\end{array}$ & CRSP \\
\hline Ln(Book_market) & $\begin{array}{l}\text { Natural logarithm of the ratio of book value of common equity } \\
\text { to market capitalization, using data from the closest past } \\
\text { quarterly earnings announcements. All negative book values are } \\
\text { excluded }\end{array}$ & Compustat \\
\hline $\begin{array}{l}\text { Institutional } \\
\text { ownership }\end{array}$ & $\begin{array}{l}\text { The proportion of a firm's equity held by institutional investors, } \\
\text { using data from the closest observed quarterly institutional } \\
\text { holdings report. Values exceeding } 100 \% \text { are excluded. }\end{array}$ & $\begin{array}{l}\text { Thomson } \\
\text { Reuters }\end{array}$ \\
\hline Past month return & $\begin{array}{l}\text { Market-adjusted return of a stock over the period of one } \\
\text { calendar month prior to a trade. This variable is expressed in } \\
\text { percents. }\end{array}$ & CRSP \\
\hline Past year return & $\begin{array}{l}\text { Market-adjusted return of a stock over the period of one } \\
\text { calendar year prior to a trade, excluding the prior month. This } \\
\text { variable is expressed in percents. }\end{array}$ & CRSP \\
\hline
\end{tabular}


An indicator variable that takes value one for a firm-year in

CEO duality which the CEO also holds a director position, and takes value zero otherwise

Board independence

Abs(Announcement return $(1,5))$
The proportion of the board of director that are independent directors for each firm-year

ISS

Absolute value of market-adjusted return on a stock from trading day $\mathrm{t}+1$ to trading day $\mathrm{t}+5$ after the day the next earnings announcement is released. This variable is expressed CRSP in percents.

Panel C: Trade characteristics

The aggregated daily excess return for a stock from trading day

Market-adjusted

return $(0,30)$

Sensitive trading $\mathrm{t}+0$ to trading day $\mathrm{t}+30$ after a transaction. The daily excess return is computed as the difference between the stock daily

CRSP return and the daily CRSP value-weighted market index. This variable is expressed in percents.

Number of days from the trading day to the closest major

Thomson corporate event. Values exceeding 120 are excluded.

Reuters

An indicator variable that takes value one if a trade is executed

Thomson in the $t-10$ to $t+3$ trading day window around an earnings

Reuters announcement

An indicator variable that takes value one if the inside reports a trade after the reporting deadline, and takes value zero otherwise. Before August 2002, the deadline is before the $10^{\text {th }}$ day of the next calendar month. After August 2002, deadline is Thomson Reuters within 2 trading days from the transaction day

Panel D: Determinants of firms ' political involvement

Ln(Sales) Natural logarithm of sales

Compustat

$\operatorname{Ln}$ (Employees)

Natural logarithm of the number of employees

Compustat

Business segments

Number of firm's business segments

Compustat

Segment

Geographic segments Number of firm's geographic segments

Compustat

Segment 
Leverage

Cash flows

Market share

Herfindahl index

Government

purchases

Political active firms

Percent unionized
The sum of long-term debt and debt in current liability, scaled by total assets

(Operating income before depreciation - interest expenses taxes - preferred dividends - common dividends)/total assets

Compustat

Compustat

The firm's sales over total sales of the industry

$$
H H I=\sum_{i=1}^{N} s_{i}^{2}
$$

where $\mathrm{s}_{\mathrm{i}}$ is the market share of firm $\mathrm{i}$ in the industry and $\mathrm{N}$ is the number of firms in the industry

An indicator variable that takes value one if a firm's one-digit SIC code is 6 or its two-digit SIC code is 49 , and zero otherwise

Percent of total industry customers that are federal or state governments

US

Economic

Census

Number of firms in a firm's industry that are making political contributions in the same cycle

FEC

Hirsch and MacPherson (2003)

\section{Panel E: Determinants of insiders' political involvement}

Age Current year - Year of birth

BoardEx

Years in role

Number of years that an insider has been in the position

BoardEx

Ln(Network size)

Number of overlaps through employment, other activities and educaton

BoardEx

Director

An indicator variable that takes value one if the insider is a director and zero otherwise

BoardEx

An indicator variable that takes value one if the insider is a

Male male and zero otherwise

BoardEx

American

An indicator variable that takes value one if the insider is an American and zero otherwise

BoardEx 
Boards

Current boards

No. of directors

$\operatorname{Ln}($ Compensation)

Politically active insiders
Total number of boards for firms (private and public) that an insider has served on

Total number of boards for firms (private and public) that an insider is serving on

Number of directors at the firm where an insider is serving

Natural logarithm of an insider's salary plus bonuses

Number of insiders in an insider's firm that are making political contributions in the same cycle
BoardEx

BoardEx

BoardEx

BoardEx

FEC 


\section{Appendix C: Determinants of firms’ political involvement}

This table presents the coefficients of the first-stage probit model, which is used to calculate the inverse Mills ratio for the firms. The model is estimated for all firms on merged Compustat/CRSP database with non-missing values for the independent variables for each election cycle from 1980 to 2016. The dependent variable is an indicator equal to one if the firm makes at least one donation to any political candidate in that cycle and zero otherwise. Industries are defined using Fama-French 48 industry definitions. All independent variables are defined in Appendix B. Election cycle fixed effects are included.

\begin{tabular}{|c|c|}
\hline \multicolumn{2}{|l|}{ First stage Probit model } \\
\hline Intercept & $\begin{array}{c}-4.128 * * * \\
(-26.84)\end{array}$ \\
\hline $\operatorname{Ln}($ Size $)$ & $\begin{array}{c}0.158 * * * \\
(18.52)\end{array}$ \\
\hline Ln(Sales) & $\begin{array}{c}0.180 * * * \\
(14.54)\end{array}$ \\
\hline Ln(Employees) & $\begin{array}{c}0.077 * * * \\
(7.21)\end{array}$ \\
\hline Business segments & $\begin{array}{c}0.040 * * * \\
(8.28)\end{array}$ \\
\hline Geographic segments & $\begin{array}{c}-0.013 * * * \\
(-2.74)\end{array}$ \\
\hline Book-to-market & $\begin{array}{c}-0.012 \\
(-1.30=)\end{array}$ \\
\hline Leverage & $\begin{array}{c}0.142 * * * \\
(4.39)\end{array}$ \\
\hline Cash flow & $\begin{array}{c}0.050 * * * \\
(2.76)\end{array}$ \\
\hline Market share & $\begin{array}{l}0.290 \\
(0.69)\end{array}$ \\
\hline$(\text { Market share })^{2}$ & $\begin{array}{l}0.429 \\
(0.58)\end{array}$ \\
\hline Herfindahl index & $\begin{array}{l}0.134 \\
(0.85)\end{array}$ \\
\hline Regulation indicator & $\begin{array}{c}0.092 * * * \\
(3.10)\end{array}$ \\
\hline Government purchases & $\begin{array}{c}0.921 * * * \\
(4.90)\end{array}$ \\
\hline Politically active firms & $\begin{array}{c}0.006^{* * *} \\
(6.40)\end{array}$ \\
\hline Percent unionized & $\begin{array}{c}0.654 * * * \\
(10.01)\end{array}$ \\
\hline $\mathrm{N}$ & 50,973 \\
\hline
\end{tabular}




\section{Appendix D: Determinants of insiders' political involvement}

This table presents the coefficients of the first-stage probit model, which is used to calculate the inverse Mills ratio for the insiders. The model is estimated for all insiders on Form 4 Thomson Reuter database with non-missing values for the independent variables for each election cycle from 1996 to 2016. The dependent variable is an indicator equal to one if the insider makes at least one donation to any political candidate in that cycle and zero otherwise. Industries are defined using Fama-French 48 industry definitions. All independent variables are defined in Appendix B. If the insiders hold positions in more than one firm in that cycle, the average value for Years to retirement, Years in role, and No. of politically active insiders and the total value of Compensation are calculated. Election cycle fixed effects are included.

\begin{tabular}{lc}
\hline First stage Probit model & \\
\hline Intercept & $5.186^{* * *}$ \\
Age & $(19.55)$ \\
& $-0.101^{* * *}$ \\
Years to retirement & $(-20.68)$ \\
& $0.104^{* * *}$ \\
Ln(Network size) & $(29.92)$ \\
& $0.006^{* * *}$ \\
Director & $(9.26)$ \\
& $0.073^{* * *}$ \\
Male & $(26.56)$ \\
& $0.316^{* * *}$ \\
American & $(18.37)$ \\
& $0.212^{* * *}$ \\
Boards & $(19.54)$ \\
& $0.084^{* * *}$ \\
Current boards & $(12.36)$ \\
& $0.009^{* * *}$ \\
No. of directors & $(15.13)$ \\
Ln(Compensation) & 0.001 \\
Politically active insiders & $(1.15)$ \\
& $0.011^{* * *}$ \\
N & $(8.82)$ \\
& $0.002^{* * *}$ \\
& $(4.79)$ \\
\hline & 201,240 \\
&
\end{tabular}




\section{Appendix E: Relationship list}

This table presents the list of the insider's roles or positions within the company, as reported on the filing. The positions are grouped into three different categories: Directors, Officers and Other.

\begin{tabular}{cl}
\hline \multirow{2}{*}{ Directors } & \multicolumn{1}{c}{ Positions } \\
& $\begin{array}{l}\text { Chairman of the Board, Director, Director and Beneficial Owner of more than 10\% of a } \\
\text { Class of security, Vice Chairman }\end{array}$ \\
\hline \multirow{2}{*}{ Officers } & $\begin{array}{l}\text { Assistant Vice President, Chief Executive Officer, Chief Financial Officer, Chief } \\
\text { Investment Officer, Chief Operating Officer, Chief Technology Officer, Executive Vice } \\
\text { President, Officer, Officer and Beneficial Owner of more than 10\% of a Class of } \\
\text { security, Officer or Parent Company, Officer and Treasurer, Divisional Officer, }\end{array}$ \\
& President, Senior Vice President, Vice President, Secretary \\
\hline \multirow{2}{*}{ Other } & $\begin{array}{l}\text { Affiliated Person, Affiliate of Investment Advisor, General Counsel, Investment } \\
\text { Advisor, Controller, Controlling Person, Indirect Shareholder, Former, General } \\
\text { Manager, General Partner, Managing Director, Other Executive, Retired, Shareholder, } \\
\text { Trustee, Treasurer, Unknown, Voting Trustee, Deceased }\end{array}$ \\
\hline
\end{tabular}




\section{REFERENCES}

Aggarwal, R. K., Meschke, F., \& Wang, T. Y. (2012). Corporate political donations: investment or agency?. Business and Politics, 14(1), 1-38.

Agrawal, A., \& Nasser, T. (2012). Insider trading in takeover targets. Journal of Corporate Finance, 18(3), 598-625.

Akey, P. (2015). Valuing changes in political networks: Evidence from campaign contributions to close congressional elections. The Review of Financial Studies, 28(11), 3188-3223.

Akin, O., Coleman, N. S., Fons-Rosen, C., \& Peydró, J. L. (2016). Political connections: Evidence from insider trading around TARP (No. 1542).

Alldredge, D. M., \& Cicero, D. C. (2015). Attentive insider trading. Journal of Financial Economics, 115(1), 84-101.

Ausubel, L. M. (1990). Insider trading in a rational expectations economy. The American Economic Review, 1022-1041.

Bessembinder, H., \& Zhang, F. (2013). Firm characteristics and long-run stock returns after corporate events. Journal of Financial Economics, 109(1), 83-102.

Bettis, J. C., Coles, J. L., \& Lemmon, M. L. (2000). Corporate policies restricting trading by insiders. Journal of Financial Economics, 57(2), 191-220.

Bettis, C., Vickrey, D., \& Vickrey, D. W. (1997). Mimickers of corporate insiders who make largevolume trades. Financial Analysts Journal, 57-66.

Betton, S., Eckbo, B. E., \& Thorburn, K. S. (2008). Corporate takeovers. Handbook of empirical corporate finance (pp. 291-429). Elsevier.

Betzer, A., Gider, J., Metzger, D., \& Theissen, E. (2014). Stealth trading and trade reporting by corporate insiders. Review of Finance, 19(2), 865-905.

Biggerstaff, L., Cicero, D. C., \& Wintoki, M. B. (2015). Insider trading patterns. Available at SSRN 2128127.

Bourveau, T., Coulomb, R., \& Sangnier, M. (2016). Political connections and insider trading.

Brennan, M. J., \& Subrahmanyam, A. (1995). Investment analysis and price formation in securities markets. Journal of financial economics, 38(3), 361-381.

Brickley, J. A., Coles, J. L., \& Jarrell, G. (1997). Leadership structure: Separating the CEO and chairman of the board. Journal of corporate Finance, 3(3), 189-220.

Brickley, J. A., Coles, J. L., \& Terry, R. L. (1994). Outside directors and the adoption of poison pills. Journal of financial Economics, 35(3), 371-390.

Brochet, F. (2010). Information content of insider trades before and after the Sarbanes-Oxley Act. The Accounting Review, 85(2), 419-446.

Certo, S. T., Busenbark, J. R., Woo, H. S., \& Semadeni, M. (2016). Sample selection bias and Heckman models in strategic management research. Strategic Management Journal, 37(13), 2639-2657.

Chari, V. V., Jagannathan, R., \& Ofer, A. R. (1988). Seasonalities in security returns: The case of earnings announcements. Journal of Financial Economics, 21(1), 101-121.

Chen, H., Parsley, D., \& Yang, Y. W. (2010). Corporate lobbying and financial performance.

Cheng, Q., \& Lo, K. (2006). Insider trading and voluntary disclosures. Journal of Accounting Research, 44(5), 815-848.

Cheng, S., Nagar, V., \& Rajan, M. V. (2007). Insider trades and private information: the special case of delayed-disclosure trades. The Review of Financial Studies, 20(6), 1833-1864. 
Claessens, S., Feijen, E., \& Laeven, L. (2008). Political connections and preferential access to finance: The role of campaign contributions. Journal of financial economics, 88(3), 554580.

Cline, B. N., \& Houston, C. (2018). Insider Filing Violations and Purposeful Information Delay.

Cohen, L., Malloy, C., \& Pomorski, L. (2012). Decoding inside information. The Journal of Finance, 67(3), 1009-1043.

Cooper, M. J., Gulen, H., \& Ovtchinnikov, A. V. (2010). Corporate political contributions and stock returns. The Journal of Finance, 65(2), 687-724.

Correia, M. M. (2014). Political connections and SEC enforcement. Journal of Accounting and Economics, 57(2-3), 241-262.

Cull, R., Li, W., Sun, B., \& Xu, L. C. (2015). Government connections and financial constraints: Evidence from a large representative sample of Chinese firms. Journal of Corporate Finance, 32, 271-294.

Dai, L., Fu, R., Kang, J. K., \& Lee, I. (2016). Corporate governance and the profitability of insider trading. Journal of Corporate Finance, 40, 235-253.

Duchin, R., \& Sosyura, D. (2012). The politics of government investment. Journal of Financial Economics, 106(1), 24-48.

Elliott, J., Morse, D., \& Richardson, G. (1984). The association between insider trading and information announcements. The RAND Journal of Economics, 521-536.

Faccio, M., Masulis, R. W., \& McConnell, J. J. (2006). Political connections and corporate bailouts. The Journal of Finance, 61(6), 2597-2635.

Fama, E. F., \& Jensen, M. C. (1983). Separation of ownership and control. The journal of law and Economics, 26(2), 301-325.

Fernandes, N., \& Ferreira, M. A. (2008). Insider trading laws and stock price informativeness. The Review of Financial Studies, 22(5), 1845-1887.

Fidrmuc, J. P., Goergen, M., \& Renneboog, L. (2006). Insider trading, news releases, and ownership concentration. The Journal of Finance, 61(6), 2931-2973.

Fulmer, S., Knill, A. M., \& Yu, X. (2012). Political contributions and the severity of government enforcement. Unpublished manuscript, Florida State University.

Gillan, S. L. (2006). Recent developments in corporate governance: An overview.

Givoly, D., \& Palmon, D. (1985). Insider trading and the exploitation of inside information: Some empirical evidence. Journal of business, 69-87.

Grier, K. B., Munger, M. C., \& Roberts, B. E. (1994). The determinants of industry political activity, 1978-1986. American political science review, 88(4), 911-926.

Goldman, E., Rocholl, J., \& So, J. (2008). Do politically connected boards affect firm value?. The Review of Financial Studies, 22(6), 2331-2360.

Heckman, J. J. (1979). Sample selection bias as a specification error. Econometrica: Journal of the econometric society, 153-161.

Hillier, D., Korczak, A., \& Korczak, P. (2015). The impact of personal attributes on corporate insider trading. Journal of Corporate Finance, 30, 150-167.

Huddart, S., Ke, B., \& Petroni, K. (2003). What insiders know about future earnings and how they use it: Evidence from insider trades. Journal of Accounting and Economics, 35(3), 315-346.

Huddart, S., Ke, B., \& Shi, C. (2007). Jeopardy, non-public information, and insider trading around SEC 10-K and 10-Q filings. Journal of Accounting and Economics, 43(1), 3-36.

Jaffe, J. F. (1974). Special information and insider trading. The Journal of Business, 47(3), 410428. 
Jagolinzer, A. D., Larcker, D. F., Ormazabal, G., \& Taylor, D. J. (2017). Political connections and the informativeness of insider trades.

Jagolinzer, A. D., Larcker, D. F., \& Taylor, D. J. (2011). Corporate governance and the information content of insider trades. Journal of Accounting Research, 49(5), 1249-1274.

Jayachandran, S. (2006). The jeffords effect. The Journal of Law and Economics, 49(2), 397-425.

Jeng, L. A., Metrick, A., \& Zeckhauser, R. (2003). Estimating the returns to insider trading: A performance-evaluation perspective. Review of Economics and Statistics, 85(2), 453-471.

Jensen, M. C., \& Meckling, W. H. (1976). Theory of the firm: Managerial behavior, agency costs and ownership structure. Journal of financial economics, 3(4), 305-360.

Jenter, D. (2005). Market timing and managerial portfolio decisions. The Journal of Finance, 60(4), 1903-1949.

Kedia, S., \& Rajgopal, S. (2011). Do the SEC's enforcement preferences affect corporate misconduct?. Journal of Accounting and Economics, 51(3), 259-278.

Khademian, A. M. (1992). The SEC and capital market regulation: The politics of expertise. University of Pittsburgh Pre.

Lakonishok, J., \& Lee, I. (2001). Are insider trades informative?. The Review of Financial Studies, $14(1), 79-111$.

Lorie, J. H., \& Niederhoffer, V. (1968). Predictive and statistical properties of insider trading. The Journal of Law and Economics, 11(1), 35-53.

Marin, J. M., \& Olivier, J. P. (2008). The dog that did not bark: Insider trading and crashes. The Journal of Finance, 63(5), 2429-2476.

Masters, M. S., \& Keim, G. D. (1986). Variation in corporate PAC and lobbying activity: An organizational and environmental analysis. Research in corporate social performance and policy, 8, 249-271.

Michaely, R., Thaler, R. H., \& Womack, K. L. (1995). Price reactions to dividend initiations and omissions: Overreaction or drift? the Journal of Finance, 50(2), 573-608.

Milyo, J., Primo, D., \& Groseclose, T. (2000). Corporate PAC campaign contributions in perspective. Business and Politics, 2(1), 75-88.

Park, S., Jang, H. J., \& Loeb, M. P. (1995). Insider trading activity surrounding annual earnings announcements. Journal of Business Finance \& Accounting, 22(4), 587-614.

Penman, S. H. (1982). Insider trading and the dissemination of firms' forecast information. Journal of Business, 479-503.

Pi, L., \& Timme, S. G. (1993). Corporate control and bank efficiency. Journal of Banking \& Finance, 17(2-3), 515-530.

Piotroski, J. D., \& Roulstone, D. T. (2005). Do insider trades reflect both contrarian beliefs and superior knowledge about future cash flow realizations?. Journal of Accounting and Economics, 39(1), 55-81.

Poole, K. T., \& Romer, T. (1985). Patterns of political action committee contributions to the 1980 campaigns for the United States House of Representatives. Public Choice, 47(1), 63-111.

Ravina, E., \& Sapienza, P. (2009). What do independent directors know? Evidence from their trading. The Review of Financial Studies, 23(3), 962-1003.

Rechner, P. L., \& Dalton, D. R. (1991). CEO duality and organizational performance: A longitudinal analysis. Strategic Management Journal, 12(2), 155-160.

Rogers, J. L. (2008). Disclosure quality and management trading powers. Journal of Accounting Research, 46(5), 1265-1296. 
Rogers, J. L., Skinner, D. J., \& Zechman, S. L. (2016). The role of the media in disseminating insider-trading news. Review of Accounting Studies, 21(3), 711-739.

Rozeff, M. S., \& Zaman, M. A. (1988). Market efficiency and insider trading: New evidence. Journal of Business, 25-44.

Skaife, H. A., Veenman, D., \& Wangerin, D. (2013). Internal control over financial reporting and managerial rent extraction: Evidence from the profitability of insider trading. Journal of Accounting and Economics, 55(1), 91-110.

Stratmann, T. (1995). Campaign contributions and congressional voting: does the timing of contributions matter?. The Review of Economics and Statistics, 127-136.

Stoll, H. R. (1978). The supply of dealer services in securities markets. The Journal of Finance, 33(4), 1133-1151.

Tahoun, A. (2014). The role of stock ownership by US members of Congress on the market for political favors. Journal of Financial Economics, 111(1), 86-110.

Weingast, B. R. (1984). The congressional-bureaucratic system: a principal agent perspective (with applications to the SEC). Public Choice, 44(1), 147-191.

Yohn, T. L. (1998). Information asymmetry around earnings announcements. Review of Quantitative Finance and Accounting, 11(2), 165-182.

Yu, F., \& Yu, X. (2011). Corporate lobbying and fraud detection. Journal of Financial and

Quantitative Analysis, 46(6), 1865-1891. 


\section{Table 1: Contribution characteristics}

This table presents firms' (Panel A) and corporate insiders' (Panel B) contribution characteristics for the sample of firms-insiders from Insider Trading file (Thomson Reuters) for each election cycle from 1980 to 2016: total number of firms (insiders), number of firms (insiders) that make political contributions, total dollar value of contributions per firm (insider), average dollar value of contribution per firm (insider) per candidate, number of candidates supported per firm (per insider). Data on political contributions are from the Federal Election Commission (FEC).

\begin{tabular}{|c|c|c|c|c|c|c|c|c|c|c|c|}
\hline \multicolumn{12}{|c|}{ Panel A: Firms } \\
\hline \multirow{2}{*}{$\begin{array}{l}\text { Election } \\
\text { cycle }\end{array}$} & \multirow{2}{*}{$\begin{array}{c}\text { Total } \\
\text { number }\end{array}$} & \multirow{2}{*}{$\begin{array}{l}\text { Number } \\
\text { donating }\end{array}$} & \multirow{2}{*}{$\begin{array}{c}\% \text { of firms } \\
\text { donating }\end{array}$} & \multirow{2}{*}{$\begin{array}{c}\text { Total \$ } \\
\text { donating }\end{array}$} & \multicolumn{6}{|c|}{ Average \$/candidate } & \multirow{2}{*}{$\begin{array}{c}\text { Number } \\
\text { candidates } \\
\text { donated }\end{array}$} \\
\hline & & & & & Mean & Min & $25^{\text {th }} \mathrm{pct}$ & Median & $75^{\text {th }} \mathrm{pct}$ & Max & \\
\hline 1980 & & 613 & & 28,976 & 565 & 4 & 250 & 500 & 700 & 4,500 & 47.63 \\
\hline 1982 & & 729 & & 34,856 & 814 & 25 & 500 & 500 & 1,000 & 2,500 & 46.53 \\
\hline 1984 & & 802 & & 41,966 & 1,636 & 20 & 500 & 500 & 1,000 & 6,000 & 49.68 \\
\hline 1986 & 5,798 & 891 & 0.15 & 49,191 & 906 & 5 & 350 & 500 & 1,000 & 7,000 & 47.60 \\
\hline 1988 & 8,637 & 921 & 0.11 & 55,814 & 1,015 & 5 & 350 & 500 & 1,000 & 8,000 & 46.90 \\
\hline 1990 & 8,632 & 897 & 0.10 & 57,801 & 1,081 & 10 & 500 & 1,000 & 1,500 & 9,000 & 43.84 \\
\hline 1992 & 8,809 & 883 & 0.10 & 69,346 & 1,135 & 10 & 500 & 1,000 & 1,800 & 9,000 & 47.37 \\
\hline 1994 & 10,449 & 831 & 0.08 & 77,288 & 1,230 & 15 & 500 & 1,000 & 2,000 & 10,000 & 48.31 \\
\hline 1996 & 11,603 & 841 & 0.07 & 83,011 & 1,415 & 15 & 500 & 1,000 & 2,000 & 10,000 & 50.19 \\
\hline 1998 & 12,700 & 816 & 0.06 & 81,714 & 1,415 & 5 & 500 & 1,000 & 2,000 & 10,000 & 47.54 \\
\hline 2000 & 12,519 & 776 & 0.06 & 99,567 & 1,662 & 25 & 1,000 & 1,000 & 2,500 & 10,000 & 48.68 \\
\hline 2002 & 10,423 & 737 & 0.07 & 108,479 & 1,730 & 25 & 1,000 & 1,000 & 3,000 & 10,000 & 47.65 \\
\hline 2004 & 9,433 & 754 & 0.08 & 124,786 & 2,055 & 8 & 1,000 & 2,000 & 3,750 & 10,000 & 45.49 \\
\hline 2006 & 9,291 & 747 & 0.08 & 150,277 & 2,366 & 49 & 1,000 & 2,000 & 4,250 & 10,000 & 48.07 \\
\hline 2008 & 9,534 & 747 & 0.08 & 174,947 & 2,499 & 25 & 1,000 & 2,000 & 5,000 & 10,000 & 52.79 \\
\hline 2010 & 8,012 & 772 & 0.10 & 172,502 & 2,646 & 25 & 1,000 & 2,400 & 5,000 & 10,000 & 52.46 \\
\hline 2012 & 7,545 & 767 & 0.10 & 197,654 & 2,794 & 40 & 1,000 & 2,500 & 5,000 & 10,000 & 54.98 \\
\hline 2014 & 7,164 & 737 & 0.10 & 233,801 & 2,943 & 50 & 1,500 & 2,500 & 5,000 & 10,000 & 59.84 \\
\hline 2016 & 6,735 & 726 & 0.11 & 234,800 & 3,110 & 34 & 1,500 & 3,000 & 5,000 & 10,000 & 58.86 \\
\hline
\end{tabular}


Table 1: Contribution characteristics (continued)

\begin{tabular}{|c|c|c|c|c|c|c|c|c|c|c|c|c|}
\hline \multicolumn{13}{|c|}{ Panel B: Insiders } \\
\hline \multirow{2}{*}{$\begin{array}{c}\text { Election } \\
\text { cycle }\end{array}$} & \multirow{2}{*}{$\begin{array}{c}\text { Total } \\
\text { number }\end{array}$} & \multirow{2}{*}{$\begin{array}{l}\text { Number } \\
\text { donating }\end{array}$} & \multirow{2}{*}{$\begin{array}{c}\% \text { of } \\
\text { insiders } \\
\text { donating }\end{array}$} & \multirow{2}{*}{$\begin{array}{c}\text { Total \$ } \\
\text { donating }\end{array}$} & \multicolumn{7}{|c|}{ Average \$/candidate } & \multirow{2}{*}{$\begin{array}{c}\text { Number } \\
\text { candidates } \\
\text { donated }\end{array}$} \\
\hline & & & & & Mean & Min & $25^{\text {th }} \mathrm{pct}$ & Median & $\begin{array}{l}75^{\text {th }} \\
\text { pct }\end{array}$ & $99^{\text {th }}$ pct & $\operatorname{Max}$ & \\
\hline 1980 & & 15,525 & & 1,970 & 617 & 5 & 250 & 500 & 1,000 & 2,000 & 5,000 & 1.99 \\
\hline 1982 & & 10,657 & & 3,088 & 826 & 50 & 500 & 1,000 & 1,000 & 2,000 & 3,000 & 2.04 \\
\hline 1984 & & 14,108 & & 3,089 & 824 & 250 & 500 & 1,000 & 1,000 & 2,000 & 6,000 & 2.09 \\
\hline 1986 & 29,965 & 16,554 & 0.55 & 2,815 & 845 & 250 & 500 & 1,000 & 1,000 & 2,000 & 25,000 & 2.04 \\
\hline 1988 & 76,098 & 21,574 & 0.28 & 3,169 & 864 & 200 & 500 & 1,000 & 1,000 & 2,000 & 23,000 & 2.10 \\
\hline 1990 & 75,372 & 27,364 & 0.36 & 2,869 & 680 & 200 & 300 & 500 & 1,000 & 2,000 & 9,070 & 2.24 \\
\hline 1992 & 73,908 & 35,964 & 0.49 & 3,500 & 702 & 200 & 250 & 500 & 1,000 & 2,000 & 25,000 & 2.60 \\
\hline 1994 & 97,833 & 35,925 & 0.37 & 3,525 & 745 & 200 & 300 & 500 & 1,000 & 2,000 & 25,000 & 2.73 \\
\hline 1996 & 106,374 & 43,145 & 0.41 & 4,161 & 774 & 200 & 450 & 750 & 1,000 & 2,000 & 80,000 & 2.97 \\
\hline 1998 & 109,388 & 38,330 & 0.35 & 4,314 & 809 & 200 & 400 & 700 & 1,000 & 3,000 & 25,000 & 2.85 \\
\hline 2000 & 101,178 & 47,947 & 0.47 & 7,074 & 888 & 160 & 500 & 1,000 & 1,000 & 3,000 & 42,000 & 3.08 \\
\hline 2002 & 83,447 & 32,772 & 0.39 & 6,388 & 903 & 200 & 500 & 1,000 & 1,000 & 3,000 & 39,764 & 2.51 \\
\hline 2004 & 77,111 & 28,486 & 0.37 & 4,492 & 1,128 & 58 & 300 & 750 & 1,250 & 4,000 & 37,500 & 2.25 \\
\hline 2006 & 77,444 & 44,520 & 0.57 & 10,418 & 1,150 & 38 & 500 & 1,000 & 1,500 & 4,800 & 21,800 & 3.46 \\
\hline 2008 & 75,476 & 48,176 & 0.64 & 11,118 & 1,265 & 200 & 500 & 1,000 & 2,000 & 4,600 & 50,000 & 3.92 \\
\hline 2010 & 61,224 & 39,505 & 0.65 & 12,359 & 1,230 & 200 & 500 & 1,000 & 2,000 & 4,800 & 12,000 & 3.92 \\
\hline 2012 & 62,084 & 44,429 & 0.72 & 20,185 & 1,255 & 200 & 500 & 1,000 & 2,000 & 5,000 & 17,500 & 4.27 \\
\hline 2014 & 61,081 & 35,260 & 0.58 & 45,819 & 1,463 & 200 & 500 & 1,000 & 2,000 & 5,000 & 15,800 & 4.17 \\
\hline 2016 & 61,141 & 50,767 & 0.83 & 88,068 & 1,458 & 5 & 500 & 1,000 & 2,500 & 5,400 & 13,500 & 17.33 \\
\hline
\end{tabular}


Table 2: Political index correlations

This table presents the correlations coefficients across eight political connection indices: $P I^{\text {candidates }}{ }_{\text {firm }}$,

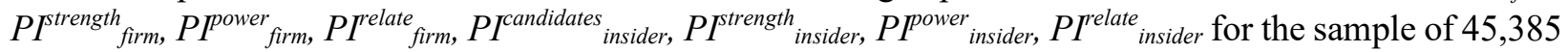
firm-election cycle observations (Panel A), 218,589 insider-election cycle observations (Panel B) and 232,524 insider-firm-election cycle observations (Panel C) for the period of 1986 to 2016. The index calculations are explained in Section 3.2.

\begin{tabular}{lcccc}
\hline \multicolumn{5}{l}{ Panel A: All firm-cycle; $N=45,385$} \\
\hline & $\mathrm{PI}^{\text {candidates }}{ }_{\text {firm }}$ & $\mathrm{PI}^{\text {strength }}{ }_{\text {firm }}$ & $\mathrm{PI}^{\text {power }}{ }_{\text {firm }}$ & $\mathrm{PI}^{\text {relate }}{ }_{\text {firm }}$ \\
\hline $\mathrm{PI}^{\text {candidates }}{ }_{\text {firm }}$ & 1.000 & 0.9132 & 0.9602 & 0.9739 \\
$\mathrm{PI}^{\text {strength }}{ }_{\text {firm }}$ & & 1.000 & 0.8453 & 0.8791 \\
$\mathrm{PI}^{\text {power }}{ }_{\text {firm }}$ & & & 1.000 & 0.9812 \\
$\mathrm{PI}^{\text {relate }}{ }_{\text {firm }}$ & & & & 1.000 \\
\hline
\end{tabular}

\begin{tabular}{lcccc}
\hline Panel B: All insider-cycle; $N=218,589$ & & & \\
\hline & $\mathrm{PI}^{\text {candidates }}{ }_{\text {insider }}$ & $\mathrm{PI}^{\text {strength }}{ }_{\text {insider }}$ & $\mathrm{PI}^{\text {power }}{ }_{\text {insider }}$ & $\mathrm{PI}^{\text {relate }}{ }_{\text {insider }}$ \\
\hline $\mathrm{PI}^{\text {candidates }_{\text {insider }}}$ & 1.000 & 0.5135 & 0.5497 & 0.5827 \\
$\mathrm{PI}^{\text {strength }}{ }_{\text {insider }}$ & & 1.000 & 0.5262 & 0.5590 \\
$\mathrm{PI}^{\text {power }_{\text {insider }}}$ & & & 1.000 & 0.7510 \\
$\mathrm{PI}^{\text {relate }}{ }_{\text {insider }}$ & & & & 1.000 \\
\hline
\end{tabular}

\begin{tabular}{|c|c|c|c|c|c|c|c|c|}
\hline \multicolumn{9}{|c|}{ Panel C: All insider-firm-cycle; $N=232,524$} \\
\hline & $(1)$ & $(2)$ & (3) & (4) & (5) & (6) & (7) & (8) \\
\hline $\mathrm{PI}^{\text {Iandidates }_{\text {firm }}(1)}$ & 1.000 & 0.9132 & 0.9602 & 0.9739 & 0.0392 & 0.0170 & 0.0214 & 0.0253 \\
\hline$P I^{\text {strength }}$ firm $(2)$ & & 1.000 & 0.8453 & 0.8791 & 0.0291 & 0.0117 & 0.0117 & 0.0176 \\
\hline $\mathrm{PI}^{\text {power }}$ firm $(3)$ & & & 1.000 & 0.9812 & 0.0420 & 0.0199 & 0.0247 & 0.0284 \\
\hline $\mathrm{PI}^{\text {relate }_{\text {firm }}}(4)$ & & & & 1.000 & 0.0402 & 0.0182 & 0.0226 & 0.0273 \\
\hline $\mathrm{PI}^{\text {candidates }_{\text {insider }}}(5)$ & & & & & 1.000 & 0.5135 & 0.5497 & 0.5827 \\
\hline $\mathrm{PI}^{\text {strength }_{\text {insider }}(6)}$ & & & & & & 1.000 & 0.5262 & 0.5590 \\
\hline $\mathrm{PI}^{\text {power }}{ }_{\text {insider }}(7)$ & & & & & & & 1.000 & 0.7510 \\
\hline $\mathrm{PI}^{\text {relate }_{\text {insider }}}$ (8) & & & & & & & & 1.000 \\
\hline
\end{tabular}




\section{Table 3: Descriptive statistics}

This table presents the summary statistics for the sample of daily corporate insiders' trades (Panel B and Panel C) and firms (Panel A) from 1986 to 2016. The whole sample are divided into two categories: observations with all political connection indices equal 0 and observations with at least one non-zero political connection index. Variables definitions are in Appendix A. In Panel A, the firm-year is classified as having non-zero political connection index if at least one insider of the firm has one non-zero political connection index. The last column presents the difference between the mean values of the two categories. The t-test statistics of the differences are in the brackets. $* * *, * *$, and $*$ indicate significance at the $1 \%, 5 \%$ and $10 \%$ levels, respectively.

\begin{tabular}{|c|c|c|c|c|c|c|c|}
\hline \multirow{2}{*}{ Variable } & \multicolumn{3}{|c|}{ All political connection indices $=0$} & \multicolumn{3}{|c|}{$\begin{array}{l}\text { At least one political connection } \\
\text { index } \neq 0\end{array}$} & \multirow{2}{*}{$\begin{array}{l}\text { Difference } \\
\text { (2)-(1) } \\
\text { (t-test) }\end{array}$} \\
\hline & $\mathrm{N}$ & Mean (1) & $\begin{array}{l}\text { Standard } \\
\text { deviation }\end{array}$ & $\mathrm{N}$ & Mean (2) & $\begin{array}{l}\text { Standard } \\
\text { deviation }\end{array}$ & \\
\hline \multicolumn{8}{|l|}{ Panel A: Firm-year level } \\
\hline Ln(Book_market) & 61,857 & -0.749 & 0.89 & 12,442 & -0.860 & 0.82 & $-0.111 * * *(-13.60)$ \\
\hline $\operatorname{Ln}($ Size $)$ & 61,857 & 5.528 & 1.85 & 12,442 & 7.503 & 2.02 & $1.975^{* * *}(100.88)$ \\
\hline Institutional ownership & 61,857 & 0.257 & 0.31 & 12,442 & 0.419 & 0.34 & $0.162 * * *(49.31)$ \\
\hline CEO duality & 61,857 & 0.327 & 0.47 & 12,442 & 0.705 & 0.46 & $0.378 * * *(83.31)$ \\
\hline Board independence & 61,857 & 0.178 & 0.32 & 12,442 & 0.468 & 0.38 & $0.291 * * *(79.80)$ \\
\hline $\mathrm{IMR}_{\text {firm }}$ & 61,857 & 1.333 & 1.16 & 12,442 & 0.962 & 0.82 & $-0.372 * * *(-42.68)$ \\
\hline $\mathrm{IMR}_{\text {insider }}$ & 61,857 & 0.295 & 0.57 & 12,442 & 0.319 & 0.54 & $0.024 * * *(4.48)$ \\
\hline $\mathrm{PI}^{\text {candidates }}{ }_{\text {firm }}$ & 61,857 & 0 & 0 & 12,442 & 69.929 & 125.54 & \\
\hline $\mathrm{PI}_{\text {ftrength }}^{\text {firm }}$ & 61,857 & 0 & 0 & 12,442 & 3876.150 & 10111.13 & \\
\hline $\mathrm{PI}^{\text {power }}{ }_{\text {firm }}$ & 61,857 & 0 & 0 & 12,442 & 446.957 & 698.80 & \\
\hline $\mathrm{PI}^{\text {relate }_{\text {firm }}}$ & 61,857 & 0 & 0 & 12,442 & 19.824 & 32.63 & \\
\hline $\mathrm{PI}^{\text {candidates }}{ }_{\text {insider }}$ & 61,857 & 0 & 0 & 12,442 & 0.167 & 0.88 & \\
\hline $\mathrm{PI}^{\text {strength }}{ }_{\text {insider }}$ & 61,857 & 0 & 0 & 12,442 & 0.404 & 10.30 & \\
\hline $\mathrm{PI}^{\text {power }_{\text {insider }}}$ & 61,857 & 0 & 0 & 12,442 & 0.138 & 3.05 & \\
\hline $\mathrm{PI}^{\text {relate }}{ }_{\text {insider }}$ & 61,857 & 0 & 0 & 12,442 & 0.007 & 0.13 & \\
\hline
\end{tabular}




\section{Table 4: Performance of politically connected insider trades}

This table presents the results from OLS regressions of insider trades' abnormal returns. The dependent variable is calculated as the cumulated market-adjusted abnormal returns of a stock from the transaction day to day 30 after an insider trade and is expressed in percents. $P I_{\text {firm }}$ is political connection index for the firm. $P I_{\text {insider }}$ is political connection index for the insider. $P I_{\text {combined }}$ is the sum of political index for the insider and the firm. The index calculations are explained in Section 3.2. Political indices are then standardized. The remaining variables are defined in Appendix A. Buy is equal one if the insider buys the stock and zero otherwise. Sell is equal one is the insider sells the stock and zero otherwise. $I M R_{\text {firm }}$ and $I M R_{\text {insider }}$ are the inverse Mills ratio calculated from Heckman's (1979) selection model. The results of the model's first stages are reported in Appendices C and D. Month-year fixed effect is included when indicated. Standard errors are clustered at the firm level. t-statistics are in the brackets. ***, **, and $*$ indicate significance at the $1 \%, 5 \%$ and $10 \%$ levels, respectively. 
Table 4: Performance of politically connected insider trades (continued)

\begin{tabular}{|c|c|c|c|c|c|c|c|c|}
\hline \multicolumn{9}{|c|}{ Panel A: Political indices for firms only } \\
\hline \multirow[b]{2}{*}{$\mathrm{PI}_{\text {firm }} * \mathrm{Buy}$} & \multicolumn{2}{|c|}{$\mathrm{PI}^{\text {candidates }}$} & \multicolumn{2}{|c|}{$\mathrm{PI}^{\text {strength }}$} & \multicolumn{2}{|c|}{$\mathrm{PI}^{\text {power }}$} & \multicolumn{2}{|c|}{$\mathrm{PI}^{\text {relate }}$} \\
\hline & 0.082 & 0.107 & 0.063 & 0.094 & 0.063 & 0.109 & 0.047 & 0.091 \\
\hline & $(1.14)$ & $(1.49)$ & $(1.27)$ & $(1.48)$ & $(0.69)$ & $(1.22)$ & $(0.55)$ & $(1.09)$ \\
\hline \multirow{2}{*}{$\mathrm{PI}_{\text {firm }}{ }^{*}$ Sell } & $-0.318 * * *$ & $-0.292 * * *$ & $-0.253 * * *$ & $-0.222 * * *$ & $-0.344 * * *$ & $-0.309 * * *$ & $-0.319 * * *$ & $-0.288 * * *$ \\
\hline & $(-6.64)$ & $(-6.17)$ & $(-5.92)$ & $(-5.32)$ & $(-6.09)$ & $(-5.65)$ & $(-6.01)$ & $(-5.64)$ \\
\hline \multirow[t]{2}{*}{ Buy } & $7.155^{* * *}$ & $3.526^{* * *}$ & $7.085 * * *$ & $3.536 * * *$ & $7.203 * * *$ & $3.522 * * *$ & $7.181 * * *$ & $3.525 * * *$ \\
\hline & $(20.09)$ & $(20.83)$ & $(20.27)$ & $(20.87)$ & $(20.01)$ & $(20.82)$ & $(20.02)$ & $(20.83)$ \\
\hline \multirow[t]{2}{*}{ Sell } & $3.866^{* * *}$ & & $3.786^{* * *}$ & & $3.919 * * *$ & & $3.893 * * *$ & \\
\hline & $(9.53)$ & & $(9.51)$ & & $(9.57)$ & & $(9.54)$ & \\
\hline \multirow[t]{2}{*}{$\mathrm{IMR}_{\text {firm }}$} & $0.471 * * *$ & $0.480 * * *$ & $0.471 * * *$ & $0.481 * * *$ & $0.469 * * *$ & $0.480 * * *$ & $0.470 * * *$ & $0.480 * * *$ \\
\hline & $(5.69)$ & (5.99) & $(5.70)$ & $(6.00)$ & $(5.67)$ & $(5.98)$ & $(5.68)$ & (5.99) \\
\hline \multirow[t]{2}{*}{ Past month return } & 0.049 & 0.040 & 0.049 & 0.040 & 0.049 & 0.040 & 0.049 & 0.040 \\
\hline & $(1.29)$ & $(0.10)$ & $(1.29)$ & $(0.10)$ & $(1.30)$ & $(0.10)$ & $(1.29)$ & $(0.09)$ \\
\hline \multirow[t]{2}{*}{ Past year return } & $0.014 * * *$ & $0.010 * * *$ & $0.014 * * *$ & $0.010 * * *$ & $0.014 * * *$ & $0.010 * * *$ & $0.014 * * *$ & $0.010 * * *$ \\
\hline & $(6.02)$ & $(4.29)$ & $(5.99)$ & $(4.27)$ & $(6.03)$ & $(4.30)$ & $(6.01)$ & $(4.29)$ \\
\hline \multirow[t]{2}{*}{$\operatorname{Ln}($ Size $)$} & $-0.505 * * *$ & $-0.465 * * *$ & $-0.491 * * *$ & $-0.450 * * *$ & $-0.515 * * *$ & $-0.471 * * *$ & $-0.511 * * *$ & $-0.468 * * *$ \\
\hline & $(-8.99)$ & $(-8.37)$ & $(-8.99)$ & $(-8.37)$ & $(-9.03)$ & $(-8.37)$ & $(-8.99)$ & $(-8.34)$ \\
\hline \multirow[t]{2}{*}{ Ln(Book_market) } & $0.818^{* * *}$ & $0.470 * * *$ & $0.827 * * *$ & $0.479 * * *$ & $0.814 * * *$ & $0.468 * * *$ & $0.814 * * *$ & $0.467 * * *$ \\
\hline & $(6.26)$ & $(3.56)$ & $(6.34)$ & $(3.36)$ & $(6.23)$ & $(3.54)$ & $(6.22)$ & $(3.53)$ \\
\hline Month-year FE & NO & YES & NO & YES & NO & YES & NO & YES \\
\hline Observations & 815,920 & 815,920 & 815,920 & 815,920 & 815,920 & 815,920 & 815,920 & 815,920 \\
\hline Adjusted R2 & 0.027 & 0.046 & 0.027 & 0.046 & 0.027 & 0.046 & 0.027 & 0.046 \\
\hline
\end{tabular}


Table 4: Performance of politically connected insider trades (continued)

\begin{tabular}{|c|c|c|c|c|c|c|c|c|}
\hline \multicolumn{9}{|c|}{ Panel B: Political indices for insiders only } \\
\hline \multirow[b]{2}{*}{$\mathrm{PI}_{\text {insider }}$ *Buy } & \multicolumn{2}{|c|}{$\mathrm{PI}^{\text {candidates }}$} & \multicolumn{2}{|c|}{$\mathrm{PI}^{\text {strength }}$} & \multicolumn{2}{|c|}{$\mathrm{PI}^{\text {power }}$} & \multicolumn{2}{|c|}{$\mathrm{PI}^{\text {relate }}$} \\
\hline & 0.034 & 0.034 & 0.010 & 0.011 & 0.028 & 0.025 & 0.313 & 0.024 \\
\hline & $(0.97)$ & $(0.97)$ & $(0.43)$ & $(0.45)$ & $(0.90)$ & $(0.67)$ & $(1.27)$ & $(0.89)$ \\
\hline \multirow[t]{2}{*}{$\mathrm{PI}_{\text {insider }}{ }^{*}$ Sell } & $-0.120 * * *$ & $-0.102 * * *$ & $-0.148 * * *$ & $-0.133 * *$ & $-0.095 * * *$ & $-0.098 * *$ & $-0.088 * *$ & $-0.079 *$ \\
\hline & $(-3.18)$ & $(-2.82)$ & $(-2.86)$ & $(-2.16)$ & $(-2.60)$ & $(-2.01)$ & $(-1.98)$ & $(-1.90)$ \\
\hline \multirow[t]{2}{*}{ Buy } & $8.075^{* * *}$ & $3.468 * * *$ & $8.061 * * *$ & $3.470 * * *$ & $8.063 * * *$ & $3.469 * * *$ & $8.064 * * *$ & $3.469 * * *$ \\
\hline & $(27.99)$ & $(20.36)$ & $(27.99)$ & $(20.36)$ & $(28.00)$ & $(20.36)$ & $(28.00)$ & $(20.35)$ \\
\hline \multirow[t]{2}{*}{ Sell } & $4.835 * * *$ & & $4.818 * * *$ & & $4.821 * * *$ & & $4.823 * * *$ & \\
\hline & $(14.64)$ & & $(14.61)$ & & $(14.62)$ & & $(14.62)$ & \\
\hline \multirow[t]{2}{*}{$\mathrm{IMR}_{\text {firm }}$} & 0.160 & 0.134 & 0.163 & 0.138 & 0.163 & 0.138 & 0.163 & 0.014 \\
\hline & $(1.56)$ & $(1.39)$ & $(1.59)$ & (1.43) & $(1.59)$ & $(1.43)$ & $(1.59)$ & $(1.43)$ \\
\hline \multirow[t]{2}{*}{ Past month return } & 0.050 & 0.041 & 0.050 & 0.041 & 0.050 & 0.041 & 0.050 & 0.041 \\
\hline & $(0.41)$ & $(0.22)$ & $(0.40)$ & $(0.22)$ & $(0.40)$ & $(0.22)$ & $(0.40)$ & $(0.22)$ \\
\hline \multirow[t]{2}{*}{ Past year return } & $0.014 * * *$ & $0.011 * * *$ & $0.014 * * *$ & $0.011 * * *$ & $0.014 * * *$ & $0.011 * * *$ & $0.143 * * *$ & $0.011 * * *$ \\
\hline & $(6.28)$ & $(4.56)$ & $(6.28)$ & $(4.56)$ & $(6.28)$ & $(4.56)$ & $(6.28)$ & $(4.56)$ \\
\hline \multirow[t]{2}{*}{$\operatorname{Ln}($ Size $)$} & $-0.579 * * *$ & $-0.543 * * *$ & $-0.576 * * *$ & $-0.540 * * *$ & $-0.576 * * *$ & $-0.541 * * *$ & $-0.576^{* * *}$ & $-0.541 * * *$ \\
\hline & $(-9.87)$ & $(-8.34)$ & $(-9.84)$ & $(8.32)$ & $(-9.85)$ & $(-8.33)$ & $(-9.85)$ & $(-8.33)$ \\
\hline \multirow[t]{2}{*}{ Ln(Book_market) } & $0.750 * * *$ & $0.403 * * *$ & $0.752 * * *$ & $0.405 * * *$ & $0.752 * * *$ & $0.405 * * *$ & $0.751 * * *$ & $0.405^{* * *}$ \\
\hline & $(5.94)$ & $(3.14)$ & $(5.96)$ & $(3.15)$ & $(5.96)$ & $(3.15)$ & $(5.96)$ & $(3.15)$ \\
\hline Month-year FE & NO & YES & NO & YES & NO & YES & NO & YES \\
\hline Observations & 815,920 & 815,920 & 815,920 & 815,920 & 815,920 & 815,920 & 815,920 & 815,920 \\
\hline Adjusted R2 & 0.026 & 0.046 & 0.026 & 0.046 & 0.026 & 0.046 & 0.026 & 0.046 \\
\hline
\end{tabular}


Table 4: Performance of politically connected insider trades (continued)

\begin{tabular}{|c|c|c|c|c|c|c|c|c|}
\hline \multicolumn{9}{|c|}{ Panel C: Political indices for both firms and insiders } \\
\hline \multirow[b]{2}{*}{$\mathrm{PI}_{\text {firm }} *$ Buy } & \multicolumn{2}{|c|}{$\mathrm{PI}^{\text {candidates }}$} & \multicolumn{2}{|c|}{$\mathrm{PI}^{\text {strength }}$} & \multicolumn{2}{|c|}{$\mathrm{PI}^{\text {power }}$} & \multicolumn{2}{|c|}{$\mathrm{PI}^{\text {relate }}$} \\
\hline & 0.079 & 0.108 & 0.061 & $0.093 *$ & 0.062 & 0.110 & 0.046 & 0.093 \\
\hline & $(1.10)$ & $(1.51)$ & $(1.22)$ & $(1.83)$ & $(0.68)$ & $(1.24)$ & $(0.53)$ & $(1.11)$ \\
\hline \multirow{2}{*}{$\mathrm{PI}_{\text {firm }} *$ Sell } & $-0.318 * * *$ & $-0.291 * * *$ & $-0.254 * * *$ & $-0.223 * * *$ & $-0.346^{* * *}$ & $-0.310 * * *$ & $-0.321 * * *$ & $-0.289 * * *$ \\
\hline & $(-6.60)$ & $(-6.13)$ & $(5.86)$ & $(-5.28)$ & $(-6.07)$ & $(-5.64)$ & $(-5.99)$ & $(-5.62)$ \\
\hline \multirow[t]{2}{*}{$\mathrm{PI}_{\text {insider }}$ *Buy } & 0.038 & 0.038 & 0.008 & 0.009 & 0.0328 & 0.031 & 0.035 & 0.028 \\
\hline & $(1.09)$ & $(1.10)$ & $(0.34)$ & $(0.36)$ & $(1.03)$ & $(0.84)$ & $(1.36)$ & $(1.04)$ \\
\hline \multirow[t]{2}{*}{$\mathrm{PI}_{\text {insider }}{ }^{*}$ Sell } & $-0.100 * * *$ & $-0.083 * *$ & $-0.043^{*}$ & $-0.082 * *$ & $-0.0887 * *$ & $-0.071^{*}$ & $-0.078 *$ & $-0.069^{*}$ \\
\hline & $(-2.72)$ & $(-2.27)$ & $(-1.66)$ & $(-2.01)$ & $(-2.31)$ & $(-1.80)$ & $(-1.73)$ & $(-1.64)$ \\
\hline \multirow[t]{2}{*}{ Buy } & $7.167 * * *$ & $3.526^{* * *}$ & $7.083 * * *$ & $3.528 * * *$ & $7.205 * * *$ & $3.523 * * *$ & $7.184 * * *$ & $3.526^{* * *}$ \\
\hline & $(20.08)$ & $(20.83)$ & $(20.62)$ & $(20.87)$ & $(20.01)$ & $(20.82)$ & $(20.02)$ & $(20.83)$ \\
\hline \multirow[t]{2}{*}{ Sell } & $3.873 * * *$ & & $3.777 * * *$ & & $3.915 * * *$ & & $3.890 * * *$ & \\
\hline & $(9.53)$ & & $(9.48)$ & & $(9.55)$ & & $(9.52)$ & \\
\hline \multirow[t]{2}{*}{$\mathrm{IMR}_{\text {firm }}$} & $0.468 * * *$ & $0.479 * * *$ & $0.469 * * *$ & $0.480 * * *$ & $0.467 * * *$ & $0.479 * * *$ & $0.468 * * *$ & $0.479 * * *$ \\
\hline & $(5.65)$ & $(5.97)$ & $(5.67)$ & $(5.99)$ & $(5.64)$ & $(5.97)$ & $(5.65)$ & $(5.97)$ \\
\hline \multirow[t]{2}{*}{$\mathrm{IMR}_{\text {insider }}$} & 0.144 & 0.132 & 0.141 & 0.132 & 0.146 & 0.136 & 0.145 & 0.134 \\
\hline & $(1.40)$ & $(1.35)$ & $(1.37)$ & $(1.35)$ & $(1.42)$ & $(1.39)$ & $(1.41)$ & $(1.38)$ \\
\hline \multirow[t]{2}{*}{ Past month return } & 0.049 & 0.040 & 0.049 & 0.040 & 0.049 & 0.040 & 0.049 & 0.040 \\
\hline & $(0.31)$ & $(0.10)$ & $(0.30)$ & $(0.10)$ & $(0.31)$ & $(0.10)$ & $(0.30)$ & $(0.10)$ \\
\hline \multirow[t]{2}{*}{ Past year return } & $0.014 * * *$ & $0.010 * * *$ & $0.014 * * *$ & $0.010 * * *$ & $0.014 * * *$ & $0.010 * * *$ & $0.014 * * *$ & $0.010 * * *$ \\
\hline & $(6.03)$ & $(4.29)$ & $(5.99)$ & $(4.27)$ & $(6.04)$ & $(4.31)$ & $(6.02)$ & $(4.29)$ \\
\hline \multirow[t]{2}{*}{$\operatorname{Ln}($ Size $)$} & $-0.515 * * *$ & $-0.469 * * *$ & $-0.497 * * *$ & $-0.452 * * *$ & $-0.522 * * *$ & -0.473 & $-0.518 * * *$ & $-0.470 * * *$ \\
\hline & $(-9.07)$ & $(-8.41)$ & $(-9.04)$ & $(-8.39)$ & $(-9.09)$ & $(-8.40)$ & $(-9.05)$ & $(-8.37)$ \\
\hline \multirow[t]{2}{*}{ Ln(Book_market) } & $0.809 * * *$ & $0.467 * * *$ & $0.819 * * *$ & $0.477 * * *$ & $0.806^{* * *}$ & $0.466 * * *$ & $0.806^{* * *}$ & $0.465^{* * *}$ \\
\hline & $(6.21)$ & $(3.53)$ & $(6.29)$ & $(3.61)$ & $(6.18)$ & $(3.52)$ & $(6.18)$ & $(3.51)$ \\
\hline Month-year FE & NO & YES & NO & YES & NO & YES & NO & YES \\
\hline Observations & 815,920 & 815,920 & 815,920 & 815,920 & 815,920 & 815,920 & 815,920 & 815,920 \\
\hline Adjusted R2 & 0.027 & 0.046 & 0.027 & 0.046 & 0.027 & 0.046 & 0.027 & 0.046 \\
\hline
\end{tabular}


Table 4: Performance of politically connected insider trades (continued)

\begin{tabular}{|c|c|c|c|c|c|c|c|c|}
\hline \multicolumn{9}{|c|}{ Panel D: Combined political indices } \\
\hline \multirow[b]{2}{*}{$\mathrm{PI}_{\text {combined }} *$ Buy } & \multicolumn{2}{|c|}{$\mathrm{PI}^{\text {candidates }}$} & \multicolumn{2}{|c|}{$\mathrm{PI}^{\text {strength }}$} & \multicolumn{2}{|c|}{$\mathrm{PI}^{\text {power }}$} & \multicolumn{2}{|c|}{$\mathrm{PI}^{\text {relate }}$} \\
\hline & 0.077 & 0.106 & 0.061 & $0.094 *$ & 0.059 & 0.108 & 0.043 & 0.090 \\
\hline & $(1.07)$ & $(1.48)$ & $(1.22)$ & $(1.83)$ & $(0.64)$ & $(1.21)$ & $(0.50)$ & $(1.08)$ \\
\hline \multirow{2}{*}{$\mathrm{PI}_{\text {combined }} *$ Sell } & $-0.322 * * *$ & $-0.294 * * *$ & $-0.255^{* * *}$ & $-0.223 * * *$ & $-0.347 * * *$ & $-0.311 * * *$ & $-0.322 * * *$ & $-0.290 * * *$ \\
\hline & $(-6.65)$ & $(-6.18)$ & $(-5.89)$ & $(-5.30)$ & $(-6.10)$ & $(-5.66)$ & $(-6.00)$ & $(-5.63)$ \\
\hline \multirow[t]{2}{*}{ Buy } & $7.156 * * *$ & 3.528 & $7.083 * * *$ & $3.538 * * *$ & $7.203 * * *$ & $3.523 * * *$ & $7.181 * * *$ & $3.527 * * *$ \\
\hline & $(20.07)$ & $(20.83)$ & $(20.26)$ & $(20.88)$ & $(20.00)$ & $(20.83)$ & $(20.01)$ & $(20.83)$ \\
\hline \multirow[t]{2}{*}{ Sell } & $3.892 * * *$ & & $3.776 * * *$ & & $3.912 * * *$ & & $3.886^{* * *}$ & \\
\hline & $(9.71)$ & & $(9.48)$ & & $(9.55)$ & & $(9.51)$ & \\
\hline \multirow[t]{2}{*}{$\mathrm{IMR}_{\text {firm }}$} & $0.468 * * *$ & $0.479 * * *$ & $0.469 * * *$ & $0.480 * * *$ & $0.467 * * *$ & $0.479 * * *$ & $0.468 * * *$ & $0.479 * * *$ \\
\hline & $(5.65)$ & $(5.98)$ & $(5.67)$ & (5.99) & $(5.64)$ & $(5.97)$ & $(5.65)$ & $(5.98)$ \\
\hline \multirow[t]{2}{*}{$\mathrm{IMR}_{\text {insider }}$} & 0.147 & 0.135 & 0.140 & 0.132 & 0.145 & 0.136 & 0.145 & 0.135 \\
\hline & $(1.42)$ & $(1.39)$ & $(1.37)$ & $(1.36)$ & $(1.42)$ & $(1.39)$ & $(1.40)$ & $(1.38)$ \\
\hline \multirow[t]{2}{*}{ Past month return } & 0.049 & 0.040 & 0.049 & 0.040 & 0.049 & 0.040 & 0.049 & 0.040 \\
\hline & $(0.31)$ & $(0.10)$ & $(0.31)$ & $(0.10)$ & $(0.32)$ & $(0.10)$ & $(0.31)$ & $(0.11)$ \\
\hline \multirow[t]{2}{*}{ Past year return } & $0.014 * * *$ & $0.010 * * *$ & $0.014 * * *$ & $0.010 * * *$ & $0.014 * * *$ & $0.010 * * *$ & $0.014 * * *$ & $0.010 * * *$ \\
\hline & $(6.02)$ & $(4.29)$ & $(5.99)$ & $(4.27)$ & $(6.04)$ & $(4.30)$ & $(6.02)$ & $(4.29)$ \\
\hline \multirow[t]{2}{*}{$\operatorname{Ln}($ Size $)$} & $-0.512 * * *$ & $-0.497 * * *$ & $-0.497 * * *$ & $-0.452 * * *$ & $-0.522 * * *$ & $-0.473 * * *$ & $-0.517 * * *$ & $-0.470 * * *$ \\
\hline & $(-9.04)$ & $(-8.39)$ & $(-9.04)$ & $(-8.39)$ & $(-9.08)$ & $(-8.39)$ & $(-9.04)$ & $(-8.36)$ \\
\hline \multirow[t]{2}{*}{ Ln(Book_market) } & $0.810 * * *$ & $0.468 * * *$ & $0.819 * * *$ & $0.477 * * *$ & $0.806^{* * *}$ & $0.466 * * *$ & $0.806^{* * *}$ & $0.465^{* * *}$ \\
\hline & $(6.22)$ & $(3.54)$ & $(6.29)$ & (3.61) & $(6.18)$ & $(3.52)$ & $(6.18)$ & $(3.51)$ \\
\hline Month-year FE & $\mathrm{NO}$ & YES & $\mathrm{NO}$ & YES & $\mathrm{NO}$ & YES & NO & YES \\
\hline Observations & 815,920 & 815,920 & 815,920 & 815,920 & 815,920 & 815,920 & 815,920 & 815,920 \\
\hline Adjusted R2 & 0.027 & 0.046 & 0.027 & 0.046 & 0.0267 & 0.046 & 0.0267 & 0.046 \\
\hline
\end{tabular}


Table 5: Performance of politically connected insider trades for different groups of insiders

This table presents the results from OLS regressions of insider trades' abnormal returns for different groups of insiders. The dependent variable is calculated as the cumulated market-adjusted abnormal returns of a stock from the transaction day to day 30 after an insider trade and is expressed in percents. $P I_{\text {combined }}$ is the sum of political index for the insider and the firm. The index calculations are explained in Section 3.2. Political indices are then standardized. The remaining variables are defined in Appendix A. Every specification includes all controls in Table 4. Month-year fixed effect is included when indicated. Standard errors are clustered at the firm level. t-statistics are in the brackets. $* * *, * *$, and $*$ indicate significance at the $1 \%, 5 \%$ and $10 \%$ levels, respectively.

\begin{tabular}{|c|c|c|c|c|}
\hline & $\mathrm{PI}^{\text {candidates }}$ & $\mathrm{PI}^{\text {strength }}$ & $\mathrm{PI}^{\text {power }}$ & $\mathrm{PI}^{\text {related }}$ \\
\hline & (1) & (2) & (3) & (4) \\
\hline \multicolumn{5}{|c|}{ Panel A: Directors (Observations $=447,600)$} \\
\hline \multirow[t]{2}{*}{$\mathrm{PI}_{\text {combined }} *$ Buy } & 0.110 & 0.089 & 0.137 & 0.119 \\
\hline & $(1.49)$ & $(1.64)$ & $(1.43)$ & $(1.33)$ \\
\hline \multirow[t]{2}{*}{$\mathrm{PI}_{\text {combined }} *$ Sell } & $-0.268 * * *$ & $-0.196 * * *$ & $-0.284 * * *$ & $-0.253 * * *$ \\
\hline & $(-3.89)$ & $(-3.45)$ & $(-3.56)$ & $(-3.24)$ \\
\hline Controls & YES & YES & YES & YES \\
\hline Month-year FE & YES & YES & YES & YES \\
\hline \multicolumn{5}{|c|}{ Panel B: Officers (Observations $=358,633)$} \\
\hline \multirow[t]{2}{*}{$\mathrm{PI}_{\text {combined }} *$ Buy } & $0.226^{*}$ & $0.214 * *$ & 0.200 & 0.188 \\
\hline & $(1.65)$ & $(2.39)$ & $(1.24)$ & $(1.22)$ \\
\hline \multirow[t]{2}{*}{$\mathrm{PI}_{\text {combined }} *$ Sell } & $-0.263 * * *$ & $-0.245 * * *$ & $-0.282 * * *$ & $-0.260 * * *$ \\
\hline & $(-4.40)$ & $(-4.25)$ & $(-4.07)$ & $(-3.85)$ \\
\hline Controls & YES & YES & YES & YES \\
\hline Month-year FE & YES & YES & YES & YES \\
\hline \multicolumn{5}{|c|}{ Panel C: Dual roles (Observations $=144,289)$} \\
\hline \multirow[t]{2}{*}{$\mathrm{PI}_{\text {combined }} *$ Buy } & 0.172 & 0.300 & 0.307 & 0.294 \\
\hline & $(1.56)$ & $(1.78)$ & $(2.09)$ & $(2.02)$ \\
\hline \multirow[t]{2}{*}{$\mathrm{PI}_{\text {combined }} *$ Sell } & $-0.417 * * *$ & $-0.347 * *$ & $-0.337 * *$ & $-0.329 * *$ \\
\hline & $(-5.70)$ & $(-5.35)$ & $(-5.24)$ & $(-5.22)$ \\
\hline Controls & YES & YES & YES & YES \\
\hline Month-year FE & YES & YES & YES & YES \\
\hline \multicolumn{5}{|c|}{ Panel D: Others (Observations $=153,976)$} \\
\hline \multirow[t]{2}{*}{$\mathrm{PI}_{\text {combined }} *$ Buy } & 0.093 & 0.023 & 0.072 & 0.028 \\
\hline & $(0.40)$ & $(0.17)$ & $(0.30)$ & $(0.11)$ \\
\hline \multirow[t]{2}{*}{ PI $I_{\text {combined }} *$ Sell } & -0.100 & -0.057 & -0.077 & -0.034 \\
\hline & $(-0.57)$ & $(-0.35)$ & $(-0.43)$ & $(-0.19)$ \\
\hline Controls & YES & YES & YES & YES \\
\hline Month-year FE & YES & YES & YES & YES \\
\hline
\end{tabular}




\section{Table 6: Performance regressions for House/Senate political indexes}

This table presents the results from OLS regressions of insider trades' abnormal returns. The dependent variable is calculated as the cumulated market-adjusted abnormal returns of a stock from the transaction day to day 30 after an insider trade and is expressed in percents. $P I_{\text {combined }}$ is the sum of political index for the insider and the firm. The index calculations are explained in Section 3.2. The House (Senate) political indexes are calculated by multiplying each equation (1) to (4) with an indicator variable equal to one if the candidate is affiliated with the House (Senate) and zero otherwise. The House (Senate) residual political indexes are the residual from the regression of House (Senate) political indexes on Senate (House) measure of the same indexes. Political indices are then standardized. The remaining variables are defined in Appendix A. Every specification includes all controls in Table 4. Month-year fixed effect is included when indicated. Standard errors are clustered at the firm level. t-statistics are in the brackets. $* * *, * *$, and * indicate significance at the $1 \%, 5 \%$ and $10 \%$ levels, respectively.

\begin{tabular}{|c|c|c|c|c|}
\hline & $\mathrm{PI}^{\text {candiates }}$ & $\mathrm{PI}^{\text {strength }}$ & PI $I^{\text {power }}$ & $\mathrm{PI}^{\text {related }}$ \\
\hline & (1) & (2) & (3) & (4) \\
\hline \multicolumn{5}{|c|}{ Panel A: Senate, House residual } \\
\hline \multirow[t]{2}{*}{$\mathrm{PI}_{\text {combined, Senate }}{ }^{*} \mathrm{Buy}$} & 0.115 & 0.059 & 0.109 & 0.100 \\
\hline & $(1.35)$ & $(0.79)$ & $(1.22)$ & $(1.04)$ \\
\hline \multirow[t]{2}{*}{$\mathrm{PI}_{\text {combined, Senate }}{ }^{*}$ Sell } & $-0.315 * * *$ & $-0.257 * * *$ & $-0.324 * * *$ & $-0.308 * * *$ \\
\hline & $(-6.32)$ & $(-5.47)$ & $(-5.96)$ & $(-5.79)$ \\
\hline \multirow[t]{2}{*}{$\mathrm{PI}_{\text {combined, House residual }} *$ Buy } & 0.044 & 0.080 & 0.052 & 0.047 \\
\hline & $(0.51)$ & $(1.31)$ & $(0.52)$ & $(0.56)$ \\
\hline \multirow[t]{2}{*}{$\mathrm{PI}_{\text {combined, House residual }} *$ Sell } & -0.047 & -0.026 & -0.046 & -0.038 \\
\hline & $(-0.94)$ & $(-0.55)$ & $(-0.84)$ & $(-0.61)$ \\
\hline Controls & YES & YES & YES & YES \\
\hline Month-year FE & YES & YES & YES & YES \\
\hline \multicolumn{5}{|c|}{ Panel B: House, Senate residual } \\
\hline \multirow[t]{2}{*}{$\mathrm{PI}_{\text {combined, House }}{ }^{*}$ Buy } & 0.092 & 0.086 & 0.085 & 0.069 \\
\hline & $(1.46)$ & $(1.56)$ & $(1.16)$ & $(0.98)$ \\
\hline \multirow[t]{2}{*}{$\mathrm{PI}_{\text {combined, House }}{ }^{*}$ Sell } & $-0.275^{* * *}$ & $-0.210 * * *$ & $-0.290 * * *$ & $-0.256 * * *$ \\
\hline & $(-6.29)$ & $(-5.09)$ & $(-5.46)$ & $(-5.62)$ \\
\hline \multirow[t]{2}{*}{$\mathrm{PI}_{\text {combined, Senate residual }} * \mathrm{Buy}$} & 0.081 & 0.045 & 0.087 & 0.088 \\
\hline & $(0.77)$ & $(0.55)$ & $(0.78)$ & $(0.81)$ \\
\hline \multirow[t]{2}{*}{$\mathrm{PI}_{\text {combined, Senate residual }} *$ Sell } & $-0.152 * * *$ & $-0.146^{* * *}$ & $-0.156^{* * *}$ & $-0.171 * *$ \\
\hline & $(-2.66)$ & $(-2.74)$ & $(-2.80)$ & $(-2.45)$ \\
\hline Controls & YES & YES & YES & YES \\
\hline Month-year FE & YES & YES & YES & YES \\
\hline
\end{tabular}




\section{Table 7: Performance regressions for Democrat/Republican political indexes}

This table presents the results from OLS regressions of insider trades' abnormal returns in different periods based on the political party in control of House/Senate. The dependent variable is calculated as the cumulated market-adjusted abnormal returns of a stock from the transaction day to day 30 after an insider trade and is expressed in percents. $P I_{\text {combined }}$ is the sum of political index for the insider and the firm. The index calculations are explained in Section 3.2. The Democrat (Republican) political indexes are calculated by multiplying each equation (1) to (4) with an indicator variable equal to one if the candidate is affiliated with the Democrat (Republican) and zero otherwise. The Democrat (Republican) residual political indexes are the residual from the regression of Democrat (Republican) political indexes on Senate (Republican) measure of the same indexes. Political indices are then standardized. The remaining variables are defined in Appendix A. Every specification includes all controls in Table 4. Month-year fixed effect is included when indicated. Standard errors are clustered at the firm level. t-statistics are in the brackets. ***, **, and * indicate significance at the $1 \%, 5 \%$ and $10 \%$ levels, respectively.

\begin{tabular}{|c|c|c|c|c|}
\hline \multicolumn{5}{|c|}{ Panel A: Republican controls both House and Senate (Observations $=461,668)$} \\
\hline & $\mathrm{PI}^{\text {candidates }}$ & $\mathrm{PI}^{\text {strength }}$ & PI power & $\mathrm{PI}^{\text {related }}$ \\
\hline & (1) & (2) & (3) & (4) \\
\hline \multicolumn{5}{|c|}{ Panel A1: Democrat, Republican residual } \\
\hline \multirow[t]{2}{*}{$\mathrm{PI}_{\text {firm, DEM }} *$ Buy } & 0.041 & 0.025 & 0.041 & 0.044 \\
\hline & $(0.61)$ & $(0.62)$ & $(0.40)$ & $(0.53)$ \\
\hline \multirow[t]{2}{*}{$\mathrm{PI}_{\text {firm, DEM }} *$ Sell } & $-0.281 * * *$ & $-0.220 * * *$ & $-0.303 * * *$ & $-0.306^{* * *}$ \\
\hline & $(-4.88)$ & $(-4.40)$ & $(-4.51)$ & $(-5.02)$ \\
\hline \multirow[t]{2}{*}{$\mathrm{PI}_{\text {firm, REP residual }} *$ Buy } & 0.107 & 0.042 & 0.111 & 0.127 \\
\hline & $(0.98)$ & $(0.39)$ & $(1.00)$ & $(1.17)$ \\
\hline \multirow[t]{2}{*}{$\mathrm{PI}_{\text {firm, REP residual }} *$ Sell } & $-0.350 * * *$ & $-0.286^{* *}$ & $-0.355^{* * *}$ & $-0.318 * *$ \\
\hline & $(-2.81)$ & $(-2.33)$ & $(-2.90)$ & $(-2.27)$ \\
\hline Controls & YES & YES & YES & YES \\
\hline Month-year FE & YES & YES & YES & YES \\
\hline \multicolumn{5}{|c|}{ Panel A2: Republican, Democrat residual } \\
\hline \multirow[t]{2}{*}{$\mathrm{PI}_{\text {firm, REP }} *$ Buy } & 0.086 & 0.039 & 0.057 & 0.025 \\
\hline & $(0.90)$ & $(0.72)$ & $(0.62)$ & $(0.30)$ \\
\hline \multirow[t]{2}{*}{$\mathrm{PI}_{\text {firm, REP }} *$ Sell } & $-0.470 * * *$ & $-0.419 * * *$ & $-0.486 * * *$ & $-0.474 * * *$ \\
\hline & $(-4.57)$ & $(-4.63)$ & $(-4.52)$ & $(-4.81)$ \\
\hline \multirow[t]{2}{*}{$\mathrm{PI}_{\text {firm, DEM residual }} *$ Buy } & 0.077 & 0.028 & 0.099 & 0.146 \\
\hline & $(0.89)$ & $(0.28)$ & $(0.87)$ & $(1.21)$ \\
\hline \multirow[t]{2}{*}{$\mathrm{PI}_{\text {firm, DEM residual }} *$ Sell } & -0.187 & -0.140 & -0.191 & $-0.219 *$ \\
\hline & $(-1.56)$ & $(-0.90)$ & $(-1.39)$ & $(-1.79)$ \\
\hline Controls & YES & YES & YES & YES \\
\hline Month-year FE & YES & YES & YES & YES \\
\hline
\end{tabular}


Table 7: Performance regressions for Democrat/Republican political indexes (continued)

\begin{tabular}{|c|c|c|c|c|}
\hline \multicolumn{5}{|c|}{ Panel B: Republican controls House, Democrat controls Senate (Observations $=214,994)$} \\
\hline & $\mathrm{PI}^{\text {candidates }}$ & $\mathrm{PI}^{\text {strength }}$ & $\mathrm{PI}^{\text {power }}$ & $\mathrm{PI}^{\text {related }}$ \\
\hline & (1) & (2) & (3) & (4) \\
\hline \multicolumn{5}{|c|}{ Panel B1: Democrat, Republican residual } \\
\hline \multirow[t]{2}{*}{$\mathrm{PI}_{\text {firm, DEM }} *$ Buy } & 0.050 & 0.035 & 0.067 & 0.079 \\
\hline & $(0.37)$ & $(0.42)$ & $(0.32)$ & $(0.60)$ \\
\hline \multirow[t]{2}{*}{$\mathrm{PI}_{\text {firm, DEM }} *$ Sell } & $-0.482 * * *$ & $-0.465 * * *$ & $-0.512 * * *$ & $-0.502 * * *$ \\
\hline & $(-5.91)$ & $(-4.51)$ & $(-5.30)$ & $(-5.71)$ \\
\hline \multirow[t]{2}{*}{$\mathrm{PI}_{\text {firm, REP residual }} *$ Buy } & 0.036 & 0.134 & 0.021 & 0.115 \\
\hline & $(0.21)$ & $(0.95)$ & $(0.32)$ & $(0.69)$ \\
\hline \multirow{2}{*}{$\mathrm{PI}_{\text {firm, REP residual }} *$ Sell } & -0.247 & -0.208 & -0.200 & -0.287 \\
\hline & $(-1.40)$ & $(-1.30)$ & $(-1.36)$ & $(-1.37)$ \\
\hline Controls & YES & YES & YES & YES \\
\hline Month-year FE & YES & YES & YES & YES \\
\hline \multicolumn{5}{|c|}{ Panel B2: Republican, Democrat residual } \\
\hline \multirow[t]{2}{*}{$\mathrm{PI}_{\text {firm, REP }} *$ Buy } & 0.060 & 0.091 & 0.141 & 0.122 \\
\hline & $(0.45)$ & $(0.84)$ & $(0.90)$ & $(0.81)$ \\
\hline \multirow[t]{2}{*}{$\mathrm{PI}_{\text {firm, REP }} *$ Sell } & $-0.440 * * *$ & $-0.341 * * *$ & $-0.486^{* * *}$ & $-0.450 * * *$ \\
\hline & $(-5.30)$ & $(-4.63)$ & $(-5.41)$ & $(-5.15)$ \\
\hline \multirow[t]{2}{*}{$\mathrm{PI}_{\text {firm, DEM residual }} *$ Buy } & 0.010 & 0.095 & 0.017 & 0.071 \\
\hline & $(0.06)$ & $(0.72)$ & $(0.12)$ & $(0.46)$ \\
\hline \multirow[t]{2}{*}{$\mathrm{PI}_{\text {firm, DEM residual }} *$ Sell } & -0.194 & -0.171 & -0.149 & -0.195 \\
\hline & $(-1.25)$ & $(-1.09)$ & $(-0.86)$ & $(-1.51)$ \\
\hline Controls & YES & YES & YES & YES \\
\hline Month-year FE & YES & YES & YES & YES \\
\hline
\end{tabular}


Table 7: Performance regressions for Democrat/Republican political indexes (continued)

\begin{tabular}{|c|c|c|c|c|}
\hline \multicolumn{5}{|c|}{ Panel C: Democrat controls both House and Senate (Observations $=139,258)$} \\
\hline & PI $I^{\text {candidates }}$ & $\mathrm{PI}^{\text {strength }}$ & PI power & PI ${ }^{\text {related }}$ \\
\hline & (1) & (2) & (3) & (4) \\
\hline \multicolumn{5}{|c|}{ Panel C1: Democrat, Republican residual } \\
\hline \multirow[t]{2}{*}{$\mathrm{PI}_{\text {firm, DEM }} *$ Buy } & 0.027 & 0.036 & 0.017 & 0.028 \\
\hline & $(0.23)$ & $(0.35)$ & $(0.11)$ & $(0.22)$ \\
\hline \multirow[t]{2}{*}{$\mathrm{PI}_{\text {firm, DEM }} *$ Sell } & $-0.432 * * *$ & $-0.512 * * *$ & $-0.501 * * *$ & $-0.507 * * *$ \\
\hline & $(-6.94)$ & $(-6.22)$ & $(-6.24)$ & $(-6.36)$ \\
\hline \multirow[t]{2}{*}{$\mathrm{PI}_{\text {firm, REP residual }} *$ Buy } & 0.014 & 0.019 & 0.021 & 0.013 \\
\hline & $(0.46)$ & $(1.26)$ & $(0.80)$ & $(0.41)$ \\
\hline \multirow{2}{*}{$\mathrm{PI}_{\text {firm, REP residual }} *$ Sell } & -0.197 & -0.167 & -0.201 & -0.135 \\
\hline & $(-1.00)$ & $(-0.60)$ & $(-0.63)$ & $(-1.06)$ \\
\hline Controls & YES & YES & YES & YES \\
\hline Month-year FE & YES & YES & YES & YES \\
\hline \multicolumn{5}{|c|}{ Panel C2: Republican, Democrat residual } \\
\hline \multirow[t]{2}{*}{$\mathrm{PI}_{\text {firm, REP }} *$ Buy } & 0.020 & 0.035 & 0.050 & 0.087 \\
\hline & $(0.17)$ & $(0.27)$ & $(0.30)$ & $(0.55)$ \\
\hline \multirow[t]{2}{*}{$\mathrm{PI}_{\text {firm, REP }} *$ Sell } & $-0.250 * *$ & $-0.274 * *$ & $-0.268 * * *$ & $-0.228 * * *$ \\
\hline & $(-2.13)$ & $(-2.35)$ & $(-2.86)$ & $(-3.12)$ \\
\hline \multirow[t]{2}{*}{$\mathrm{PI}_{\text {firm, DEM residual }} *$ Buy } & 0.068 & 0.056 & 0.017 & 0.013 \\
\hline & $(0.22)$ & $(0.32)$ & $(0.14)$ & $(0.05)$ \\
\hline \multirow{2}{*}{$\mathrm{PI}_{\text {firm, DEM residual }} *$ Sell } & $-0.399 * * *$ & $-0.389 * *$ & $-0.412 * * *$ & $-0.411 * *$ \\
\hline & $(-2.04)$ & $(-2.11)$ & $(-2.58)$ & $(-2.20)$ \\
\hline Controls & YES & YES & YES & YES \\
\hline Month-year FE & YES & YES & YES & YES \\
\hline
\end{tabular}




\section{Table 8: Robustness check for Performance regressions}

This table presents the results from OLS regressions of insider trades' abnormal returns. The sample includes one observation per insider report. Insider trades are aggregated within each report. In Panel A, transaction date is the first trading date of each report. In Panel B, transaction date is the last trading date of each report. The dependent variable is calculated as the cumulated market-adjusted abnormal returns of a stock from the transaction day to day 30 after an insider trade and is expressed in percents. $P I_{\text {combined }}$ is the sum of political index for the insider and the firm. The index calculations are explained in Section 3.2. Political indices are then standardized. The remaining variables are defined in Appendix A. Buy is equal one if the insider buys the stock and zero otherwise. Sell is equal one is the insider sells the stock and zero otherwise. $I M R_{\text {firm }}$ and $I M R_{\text {insider }}$ are the inverse Mills ratio calculated from Heckman's (1979) selection model. The results of the model's first stages are reported in Appendices C and D. Month-year fixed effect is included when indicated. Standard errors are clustered at the firm level. t-statistics are in the brackets. $* * *, * *$, and $*$ indicate significance at the $1 \%, 5 \%$ and $10 \%$ levels, respectively. 
Table 8: Robustness check for Performance regressions (continued)

\begin{tabular}{|c|c|c|c|c|c|c|c|c|}
\hline & \multicolumn{4}{|c|}{ Panel A: First trade of each report } & \multicolumn{4}{|c|}{ Panel B: Last trade of each report } \\
\hline & $\mathrm{PI}^{\text {candidates }}$ & $\mathrm{PI}^{\text {strength }}$ & PI $I^{\text {power }}$ & $\mathrm{PI}^{\text {related }}$ & $\mathrm{PI}^{\text {candidates }}$ & $\mathrm{PI}^{\text {strength }}$ & PI $I^{\text {power }}$ & $\mathrm{PI}^{\text {related }}$ \\
\hline $\mathrm{PI}_{\text {combined }} *$ Buy & $\begin{array}{l}0.163 \\
(1.35)\end{array}$ & $\begin{array}{l}0.130 \\
(1.51)\end{array}$ & $\begin{array}{l}0.169^{*} \\
(1.85)\end{array}$ & $\begin{array}{c}0.149^{*} \\
(1.80)\end{array}$ & $\begin{array}{l}0.157 \\
(1.26)\end{array}$ & $\begin{array}{l}0.134 \\
(1.60)\end{array}$ & $\begin{array}{l}0.165^{*} \\
(1.87)\end{array}$ & $\begin{array}{c}0.142 * \\
(1.70)\end{array}$ \\
\hline $\mathrm{PI}_{\text {combined }} *$ Sell & $\begin{array}{c}-0.274 * * * \\
(-5.96)\end{array}$ & $\begin{array}{c}-0.213^{* * *} \\
(-5.11)\end{array}$ & $\begin{array}{c}-0.297 * * * \\
(-5.61)\end{array}$ & $\begin{array}{c}-0.281 * * * \\
(-5.40)\end{array}$ & $\begin{array}{c}-0.250 * * * \\
(-5.43)\end{array}$ & $\begin{array}{c}-0.207 * * * \\
(-4.78)\end{array}$ & $\begin{array}{c}-0.275 * * * \\
(-5.14)\end{array}$ & $\begin{array}{c}-0.258 * * * \\
(-4.95)\end{array}$ \\
\hline Buy & $\begin{array}{c}3.512 * * * \\
(24.65)\end{array}$ & $\begin{array}{c}3.521 * * * \\
(24.68)\end{array}$ & $\begin{array}{c}3.507 * * * \\
(24.63)\end{array}$ & $\begin{array}{c}3.510 * * * \\
(24.64)\end{array}$ & $\begin{array}{c}3.532 * * * \\
(24.80)\end{array}$ & $\begin{array}{c}3.540 * * * \\
(24.80)\end{array}$ & $\begin{array}{c}3.527 * * * \\
(24.78)\end{array}$ & $\begin{array}{c}3.530 * * * \\
(24.79)\end{array}$ \\
\hline $\mathrm{IMR}_{\text {firm }}$ & $\begin{array}{c}0.548 * * * \\
(8.05)\end{array}$ & $\begin{array}{c}0.548 * * * \\
(8.06)\end{array}$ & $\begin{array}{c}0.568 * * * \\
(8.04)\end{array}$ & $\begin{array}{c}0.548 * * * \\
(8.05)\end{array}$ & $\begin{array}{c}0.548 * * * \\
(8.08)\end{array}$ & $\begin{array}{c}0.548 * * * \\
(8.09)\end{array}$ & $\begin{array}{c}0.548 * * * \\
(8.08)\end{array}$ & $\begin{array}{c}0.548 * * * \\
(8.08)\end{array}$ \\
\hline $\mathrm{IMR}_{\text {insider }}$ & $\begin{array}{l}0.066 \\
(0.71)\end{array}$ & $\begin{array}{l}0.064 \\
(0.68)\end{array}$ & $\begin{array}{l}0.068 \\
(0.72)\end{array}$ & $\begin{array}{l}0.067 \\
(0.71)\end{array}$ & $\begin{array}{l}0.076 \\
(0.81)\end{array}$ & $\begin{array}{l}0.075 \\
(0.80)\end{array}$ & $\begin{array}{l}0.079 \\
(0.84)\end{array}$ & $\begin{array}{l}0.077 \\
(0.82)\end{array}$ \\
\hline Past month return & $\begin{array}{l}0.040 \\
(0.79)\end{array}$ & $\begin{array}{l}0.040 \\
(0.79)\end{array}$ & $\begin{array}{l}0.040 \\
(0.79)\end{array}$ & $\begin{array}{l}0.040 \\
(0.79)\end{array}$ & $\begin{array}{l}0.025 \\
(0.19)\end{array}$ & $\begin{array}{l}0.025 \\
(0.19)\end{array}$ & $\begin{array}{l}0.025 \\
(0.19)\end{array}$ & $\begin{array}{l}0.025 \\
(0.19)\end{array}$ \\
\hline Past year return & $\begin{array}{c}0.013^{* * *} \\
(4.69)\end{array}$ & $\begin{array}{c}0.013 * * * \\
(4.65)\end{array}$ & $\begin{array}{c}0.013 * * * \\
(4.70)\end{array}$ & $\begin{array}{c}0.013 * * * \\
(4.69)\end{array}$ & $\begin{array}{c}0.021^{* * *} \\
(5.17)\end{array}$ & $\begin{array}{c}0.021 * * * \\
(5.14)\end{array}$ & $\begin{array}{c}0.021 * * * \\
(5.19)\end{array}$ & $\begin{array}{c}0.025 * * * \\
(5.17)\end{array}$ \\
\hline $\operatorname{Ln}($ Size $)$ & $\begin{array}{c}-0.468 * * * \\
(-9.59)\end{array}$ & $\begin{array}{c}-0.455^{* * *} \\
(-9.74)\end{array}$ & $\begin{array}{c}-0.473 * * * \\
(-9.57)\end{array}$ & $\begin{array}{c}-0.471 * * * \\
(-9.59)\end{array}$ & $\begin{array}{c}-0.435 * * * \\
(-8.94)\end{array}$ & $\begin{array}{c}-0.423 * * * \\
(-9.07)\end{array}$ & $\begin{array}{c}-0.440 * * * \\
(-8.93)\end{array}$ & $\begin{array}{c}-0.438 * * * \\
(-8.94)\end{array}$ \\
\hline Ln(Book_market) & $\begin{array}{c}0.219^{* * *} \\
(2.83)\end{array}$ & $\begin{array}{c}0.230 * * * \\
(2.91)\end{array}$ & $\begin{array}{c}0.217 * * * \\
(2.81)\end{array}$ & $\begin{array}{c}0.216^{* * *} \\
(2.80)\end{array}$ & $\begin{array}{c}0.250^{* * *} \\
(3.10)\end{array}$ & $\begin{array}{c}0.258 * * * \\
(3.17)\end{array}$ & $\begin{array}{c}0.248 * * * \\
(3.08)\end{array}$ & $\begin{array}{c}0.247 * * * \\
(3.07)\end{array}$ \\
\hline Month-year FE & YES & YES & YES & YES & YES & YES & YES & YES \\
\hline Observations & 576,954 & 576,954 & 576,954 & 576,954 & 576,954 & 576,954 & 576,954 & 576,954 \\
\hline Adjusted R2 & 0.043 & 0.043 & 0.043 & 0.043 & 0.042 & 0.042 & 0.042 & 0.042 \\
\hline
\end{tabular}




\section{Table 9: Effects of political connections on insider trading behavior: Days to the closest major corporate event.}

This table presents the results from OLS regressions of insider trading behavior. The dependent variable is the number of days to the closest major corporate event from an insider trade. $P I_{\text {combined }}$ is the sum of political index for the insider and the firm. The index calculations are explained in Section 3.2. Political indices are then standardized. Buy is equal one if the insider buys the stock and zero otherwise. Sell is equal one is the insider sells the stock and zero otherwise. $I M R_{\text {firm }}$ and $I M R_{\text {insider }}$ are the inverse Mills ratio calculated from Heckman's (1979) selection model. The results of the model's first stages are reported in Appendices C and D. The remaining variables are defined in Appendix A. Standard errors are clustered at the firm level. t-statistics are in the brackets. ${ }^{* *}, * *$, and $*$ indicate significance at the $1 \%, 5 \%$ and $10 \%$ levels, respectively. 
Table 9: Effects of political connections on insider trading behavior: Days to the closest major corporate event (continued)

\begin{tabular}{|c|c|c|c|c|c|c|c|c|}
\hline & \multicolumn{2}{|c|}{$\mathrm{PI}^{\text {candidates }}$} & \multicolumn{2}{|c|}{$\mathrm{PI}^{\text {strength }}$} & \multicolumn{2}{|c|}{ PI power } & \multicolumn{2}{|c|}{$\mathrm{PI}^{\text {relate }}$} \\
\hline & (1) & (2) & (3) & (4) & (5) & (6) & (7) & (8) \\
\hline \multirow{2}{*}{$\mathrm{PI}_{\text {firm }}{ }^{*} \mathrm{Buy}$} & $-0.485 * * *$ & $-0.219 * * *$ & $-0.430 * * *$ & $-0.243 * * *$ & $-0.486 * * *$ & $-0.280 * * *$ & $-0.553 * * *$ & $-0.224 * * *$ \\
\hline & $(-8.06)$ & $(-5.81)$ & $(-7.39)$ & $(-5.85)$ & $(-7.74)$ & $(-7.48)$ & $(-8.88)$ & $(-6.00)$ \\
\hline \multirow[t]{2}{*}{$\mathrm{PI}_{\text {firm }} *$ Sell } & $-0.654 * * *$ & $-0.615 * * *$ & $-0.648 * * *$ & $-0.619 * * *$ & $-0.671 * * *$ & $-0.588 * * *$ & $-0.678 * * *$ & $-0.658 * * *$ \\
\hline & $(-18.08)$ & $(-10.02)$ & $(-17.71)$ & $(-10.31)$ & $(-18.78)$ & $(-12.27)$ & $(-18.93)$ & $(-10.36)$ \\
\hline \multirow[t]{2}{*}{ Buy } & $58.943 * * *$ & $60.473 * * *$ & $58.946 * * *$ & $60.521 * * *$ & $58.940 * * *$ & $60.466 * * *$ & $58.942 * * *$ & $60.482 * * *$ \\
\hline & $(566.84)$ & (423.69) & $(567.11)$ & $(428.25)$ & $(566.47)$ & (421.19) & $(566.63)$ & $(422.48)$ \\
\hline \multirow[t]{2}{*}{ Sell } & $58.467 * * *$ & $60.151 * * *$ & $58.459 * * *$ & $60.201 * * *$ & $58.466 * * *$ & $60.145 * * *$ & $58.464 * * *$ & $60.161 * * *$ \\
\hline & $(588.22)$ & (368.00) & $(588.70)$ & (371.91) & $(588.09)$ & $(366.18)$ & $(588.24)$ & $(367.17)$ \\
\hline \multirow[t]{2}{*}{$\mathrm{IMR}_{\text {firm }}$} & $0.480 * * *$ & $0.159 * * *$ & $0.486 * * *$ & $0.158 * * *$ & $0.480 * * *$ & $0.159 * * *$ & $0.481 * * *$ & $0.380 * * *$ \\
\hline & $(17.60)$ & $(5.56)$ & $(17.84)$ & $(5.55)$ & $(17.58)$ & $(5.55)$ & $(17.64)$ & $(5.57)$ \\
\hline \multirow[t]{2}{*}{$\mathrm{IMR}_{\text {insider }}$} & $0.767 * * *$ & $0.897 * * *$ & $0.765 * * *$ & $0.896 * * *$ & $0.765 * * *$ & $0.893 * * *$ & $0.765 * * *$ & $0.893 * * *$ \\
\hline & $(13.46)$ & $(15.70)$ & $(13.42)$ & $(15.69)$ & $(13.42)$ & $(15.64)$ & $(13.41)$ & $(15.64)$ \\
\hline \multirow[t]{2}{*}{$\operatorname{Ln}(\operatorname{Size})$} & & $0.650 * * *$ & & $0.658 * * *$ & & $0.649 * * *$ & & $0.651 * * *$ \\
\hline & & $(27.03)$ & & $(27.65)$ & & $(26.86)$ & & $(27.03)$ \\
\hline \multirow{2}{*}{$\begin{array}{l}\text { Institutional } \\
\text { ownership }\end{array}$} & & $0.762 * * *$ & & $0.764 * * *$ & & $0.759 * * *$ & & $0.762 * * *$ \\
\hline & & $(6.85)$ & & $(6.87)$ & & $(6.83)$ & & $(6.84)$ \\
\hline \multirow{2}{*}{$\begin{array}{l}\operatorname{Abs}(\text { Announcement } \\
\text { return }(1,5))\end{array}$} & & $-0.178 * * *$ & & $-0.178 * * *$ & & $-0.177 * * *$ & & $-0.178 * * *$ \\
\hline & & $(-40.73)$ & & $(-40.71)$ & & $(-40.71)$ & & $(-40.73)$ \\
\hline \multirow[t]{2}{*}{ CEO duality } & & $1.586 * * *$ & & $1.599 * * *$ & & $1.585 * * *$ & & $1.587 * * *$ \\
\hline & & $(16.33)$ & & $(16.46)$ & & $(16.32)$ & & $(16.34)$ \\
\hline Board & & $2.333 * * *$ & & $2.323 * * *$ & & $2.332 * * *$ & & $2.328 * * *$ \\
\hline independence & & $(16.32)$ & & $(16.27)$ & & $(16.30)$ & & $(16.28)$ \\
\hline Observations & 815,920 & 810,757 & 815,920 & 810,757 & 815,920 & 810,575 & 815,920 & 810,757 \\
\hline Adjusted R2 & 0.813 & 0.815 & 0.813 & 0.815 & 0.813 & 0.815 & 0.813 & 0.815 \\
\hline
\end{tabular}




\section{Table 10: Effects of political connections on insider trading behavior: Trading during common blackout periods.}

This table presents the results from logit regressions of insider trading behavior. The dependent variable equals 1 if an insider trade happens in the windows of $(\mathrm{t}-10, \mathrm{t}+3)$ around the day that an earnings announcement is released. $P I_{\text {combined }}$ is the sum of political index for the insider and the firm. The index calculations are explained in Section 3.2. Buy is equal one if the insider buys the stock and zero otherwise. Sell is equal one is the insider sells the stock and zero otherwise. $I M R_{\text {firm }}$ and $I M R_{\text {insider }}$ are the inverse Mills ratio calculated from Heckman's (1979) selection model. The results of the model's first stages are reported in Appendices C and D. Political indices are then standardized. The remaining variables are defined in Appendix A. t-statistics are in the brackets. ${ }^{* *}, * *$, and * indicate significance at the $1 \%, 5 \%$ and $10 \%$ levels, respectively. 
Table 10: Effects of political connections on insider trading behavior: Trading during common blackout periods (continued)

\begin{tabular}{|c|c|c|c|c|c|c|c|c|}
\hline \multicolumn{9}{|l|}{ Panel A: Coefficients } \\
\hline & \multicolumn{2}{|c|}{$\mathrm{PI}^{\text {candidates }}$} & \multicolumn{2}{|c|}{$\mathrm{PI}^{\text {strength }}$} & \multicolumn{2}{|c|}{ PI power } & \multicolumn{2}{|c|}{$\mathrm{PI}^{\text {relate }}$} \\
\hline & (1) & (2) & (3) & (4) & (5) & (6) & (7) & (8) \\
\hline $\mathrm{PI}_{\text {combined }} *$ Buy & $\begin{array}{c}0.018 * * * \\
(4.90)\end{array}$ & $\begin{array}{c}0.029 * * * \\
(7.63)\end{array}$ & $\begin{array}{c}0.017 * * * \\
(2.13)\end{array}$ & $\begin{array}{c}0.021 * * * \\
(3.90)\end{array}$ & $\begin{array}{c}0.019 * * * \\
(4.70)\end{array}$ & $\begin{array}{c}0.031 * * * \\
(5.05)\end{array}$ & $\begin{array}{c}0.017 * * * \\
(4.68)\end{array}$ & $\begin{array}{c}0.021 * * * \\
(3.49)\end{array}$ \\
\hline $\mathrm{PI}_{\text {combined }} *$ Sell & $\begin{array}{c}0.020 * * * \\
(3.55)\end{array}$ & $\begin{array}{c}0.036 * * * \\
(6.07)\end{array}$ & $\begin{array}{c}0.018 * * * \\
(3.31)\end{array}$ & $\begin{array}{c}0.034 * * * \\
(5.93)\end{array}$ & $\begin{array}{c}0.027 * * * \\
(5.31)\end{array}$ & $\begin{array}{c}0.038 * * * \\
(5.88)\end{array}$ & $\begin{array}{c}0.028 * * * \\
(4.81)\end{array}$ & $\begin{array}{c}0.044 * * * \\
(9.70)\end{array}$ \\
\hline Buy & $\begin{array}{c}-1.677 * * * \\
(-275.19)\end{array}$ & $\begin{array}{c}-1.800 * * * \\
(-125.60)\end{array}$ & $\begin{array}{c}-1.676 * * * \\
(-275.29)\end{array}$ & $\begin{array}{c}-1.802 * * * \\
(-126.99)\end{array}$ & $\begin{array}{c}-1.677 * * * \\
(-275.04)\end{array}$ & $\begin{array}{c}-1.798 * * * \\
(-124.74)\end{array}$ & $\begin{array}{c}-1.677 * * * \\
(-275.10)\end{array}$ & $\begin{array}{c}-1.799 * * * \\
(-125.15)\end{array}$ \\
\hline Sell & $\begin{array}{c}-1.848 * * * \\
(-318.82)\end{array}$ & $\begin{array}{l}-2.012 * * * \\
(-121.91)\end{array}$ & $\begin{array}{c}-1.846 * * * \\
(-320.17)\end{array}$ & $\begin{array}{l}-2.014 * * * \\
(-123.26)\end{array}$ & $\begin{array}{c}-1.849 * * * \\
(-319.68)\end{array}$ & $\begin{array}{c}-2.010 * * * \\
(-121.19)\end{array}$ & $\begin{array}{c}-1.849 * * * \\
(-319.74)\end{array}$ & $\begin{array}{c}-2.011 * * * \\
(-121.54)\end{array}$ \\
\hline $\mathrm{IMR}_{\text {firm }}$ & $\begin{array}{l}0.001 \\
(0.40)\end{array}$ & $\begin{array}{c}0.016 * * * \\
(5.44)\end{array}$ & $\begin{array}{l}0.001 \\
(0.60)\end{array}$ & $\begin{array}{c}0.016 * * * \\
(5.43)\end{array}$ & $\begin{array}{l}0.001 \\
(0.54)\end{array}$ & $\begin{array}{c}0.016^{* * *} \\
(5.44)\end{array}$ & $\begin{array}{l}0.001 \\
(0.48)\end{array}$ & $\begin{array}{c}0.016^{* * *} \\
(5.43)\end{array}$ \\
\hline $\mathrm{IMR}_{\text {insider }}$ & $\begin{array}{c}0.030 * * * \\
(5.38)\end{array}$ & $\begin{array}{c}0.014 * * \\
(2.39)\end{array}$ & $\begin{array}{c}0.030 * * * \\
(5.37)\end{array}$ & $\begin{array}{c}0.014 * * \\
(2.38)\end{array}$ & $\begin{array}{c}0.030 * * * \\
(5.32)\end{array}$ & $\begin{array}{c}0.014 * * \\
(2.41)\end{array}$ & $\begin{array}{c}0.030 * * * \\
(5.33)\end{array}$ & $\begin{array}{c}0.014 * * \\
(2.41)\end{array}$ \\
\hline Ln(Size) & & $\begin{array}{c}-0.023 * * * \\
(-9.35)\end{array}$ & & $\begin{array}{c}-0.023 * * * \\
(-9.63)\end{array}$ & & $\begin{array}{c}-0.022 * * * \\
(-9.19)\end{array}$ & & $\begin{array}{c}-0.022 * * * \\
(-9.27)\end{array}$ \\
\hline $\begin{array}{l}\text { Institutional } \\
\text { ownership }\end{array}$ & & $\begin{array}{l}-0.006 \\
(-0.54)\end{array}$ & & $\begin{array}{l}-0.006 \\
(-0.53)\end{array}$ & & $\begin{array}{l}-0.006 \\
(-0.54)\end{array}$ & & $\begin{array}{l}-0.006 \\
(-0.54)\end{array}$ \\
\hline $\begin{array}{l}\text { Abs(Announcement } \\
\text { return }(1,5))\end{array}$ & & $\begin{array}{c}0.003 * * * \\
(6.56)\end{array}$ & & $\begin{array}{c}0.003 * * * \\
(6.58)\end{array}$ & & $\begin{array}{c}0.003 * * * \\
(6.56)\end{array}$ & & $\begin{array}{c}0.003 * * * \\
(6.57)\end{array}$ \\
\hline CEO duality & & $\begin{array}{l}0.005 \\
(0.56)\end{array}$ & & $\begin{array}{l}0.005 \\
(0.47)\end{array}$ & & $\begin{array}{l}0.005 \\
(0.56)\end{array}$ & & $\begin{array}{l}0.011 \\
(0.54)\end{array}$ \\
\hline $\begin{array}{l}\text { Board } \\
\text { independence }\end{array}$ & & $\begin{array}{c}-0.082 * * * \\
(-5.76)\end{array}$ & & $\begin{array}{c}-0.083 * * * \\
(-5.86)\end{array}$ & & $\begin{array}{c}-0.082 * * * \\
(-5.73)\end{array}$ & & $\begin{array}{c}-0.082 * * * \\
(-5.77)\end{array}$ \\
\hline Observations & 815,920 & 810,757 & 815,920 & 810,757 & 815,920 & 810,757 & 815,920 & 810,757 \\
\hline
\end{tabular}


Table 10: Effects of political connections on insider trading behavior: Trading during common blackout periods (continued)

\begin{tabular}{|c|c|c|c|c|c|c|c|c|}
\hline \multicolumn{9}{|c|}{ Panel B: Marginal effects } \\
\hline & \multicolumn{2}{|c|}{$\mathrm{PI}^{\text {candidates }}$} & \multicolumn{2}{|c|}{$\mathrm{PI}^{\text {strength }}$} & \multicolumn{2}{|c|}{ PI power } & \multicolumn{2}{|c|}{$\mathrm{PI}^{\text {relate }}$} \\
\hline & (1) & (2) & (3) & (4) & (5) & (6) & (7) & (8) \\
\hline $\mathrm{PI}_{\text {combined }} * \mathrm{Buy}$ & $\begin{array}{c}0.002 * * * \\
(4.90)\end{array}$ & $\begin{array}{c}0.004 * * * \\
(7.63)\end{array}$ & $\begin{array}{c}0.001 * * * \\
(2.13)\end{array}$ & $\begin{array}{c}0.003 * * * \\
(3.90)\end{array}$ & $\begin{array}{c}0.002 * * * \\
(5.31)\end{array}$ & $\begin{array}{c}0.003 * * * \\
(5.05)\end{array}$ & $\begin{array}{c}0.002 * * * \\
(4.68)\end{array}$ & $\begin{array}{c}0.003 * * * \\
(3.49)\end{array}$ \\
\hline $\mathrm{PI}_{\text {combined }} *$ Sell & $\begin{array}{c}0.002 * * * \\
(3.55)\end{array}$ & $\begin{array}{c}0.004 * * * \\
(6.07)\end{array}$ & $\begin{array}{c}0.002 * * * \\
(3.31)\end{array}$ & $\begin{array}{c}0.004 * * * \\
(5.93)\end{array}$ & $\begin{array}{c}0.003 * * * \\
(5.31)\end{array}$ & $\begin{array}{c}0.004 * * * \\
(5.88)\end{array}$ & $\begin{array}{c}0.003 * * * \\
(4.81)\end{array}$ & $\begin{array}{c}0.005 * * * \\
(9.70)\end{array}$ \\
\hline Buy & $\begin{array}{l}-0.191 * * * \\
(-326.99)\end{array}$ & $\begin{array}{c}-0.204 * * * \\
(-135.89)\end{array}$ & $\begin{array}{c}-0.191 * * * \\
(-327.14)\end{array}$ & $\begin{array}{c}-0.205 * * * \\
(-137.58)\end{array}$ & $\begin{array}{c}-0.191 * * * \\
(-326.78)\end{array}$ & $\begin{array}{c}-0.204 * * * \\
(-134.97)\end{array}$ & $\begin{array}{c}-0.191 * * * \\
(-326.87)\end{array}$ & $\begin{array}{c}-0.204 * * * \\
(-135.69)\end{array}$ \\
\hline Sell & $\begin{array}{c}-0.265 * * * \\
(-343.75)\end{array}$ & $\begin{array}{c}-0.293 * * * \\
(-109.97)\end{array}$ & $\begin{array}{c}-0.265 * * * \\
(-344.30)\end{array}$ & $\begin{array}{c}-0.293 * * * \\
(-111.30)\end{array}$ & $\begin{array}{c}-0.266 * * * \\
(-343.53)\end{array}$ & $\begin{array}{c}-0.293 * * * \\
(-109.30)\end{array}$ & $\begin{array}{c}-0.266 * * * \\
(-343.62)\end{array}$ & $\begin{array}{c}-0.293 * * * \\
(-109.63)\end{array}$ \\
\hline $\mathrm{IMR}_{\text {firm }}$ & $\begin{array}{l}0.000 \\
(0.40)\end{array}$ & $\begin{array}{c}0.002 * * * \\
(5.45)\end{array}$ & $\begin{array}{l}0.000 \\
(0.60)\end{array}$ & $\begin{array}{c}0.002 * * * \\
(5.43)\end{array}$ & $\begin{array}{l}0.000 \\
(0.54)\end{array}$ & $\begin{array}{c}0.002 * * * \\
(5.44)\end{array}$ & $\begin{array}{l}0.000 \\
(0.48)\end{array}$ & $\begin{array}{c}0.002 * * * \\
(5.43)\end{array}$ \\
\hline $\mathrm{IMR}_{\text {insider }}$ & $\begin{array}{c}0.004 * * * \\
(5.38)\end{array}$ & $\begin{array}{c}0.002 * * \\
(2.39)\end{array}$ & $\begin{array}{c}0.004 * * * \\
(5.37)\end{array}$ & $\begin{array}{c}0.002 * * \\
(2.38)\end{array}$ & $\begin{array}{c}0.004 * * * \\
(5.32)\end{array}$ & $\begin{array}{c}0.002 * * \\
(2.41)\end{array}$ & $\begin{array}{c}0.004 * * * \\
(5.33)\end{array}$ & $\begin{array}{c}0.002 * * \\
(2.41)\end{array}$ \\
\hline $\operatorname{Ln}(\operatorname{Size})$ & & $\begin{array}{c}-0.003 * * * \\
(-9.36)\end{array}$ & & $\begin{array}{c}-0.003 * * * \\
(-9.63)\end{array}$ & & $\begin{array}{c}-0.003 * * * \\
(-9.19)\end{array}$ & & $\begin{array}{c}-0.003 * * * \\
(-9.27)\end{array}$ \\
\hline $\begin{array}{l}\text { Institutional } \\
\text { ownership }\end{array}$ & & $\begin{array}{l}-0.001 \\
(-0.54)\end{array}$ & & $\begin{array}{l}-0.001 \\
(-0.53)\end{array}$ & & $\begin{array}{l}-0.001 \\
(-0.54)\end{array}$ & & $\begin{array}{l}-0.001 \\
(-0.54)\end{array}$ \\
\hline $\begin{array}{l}\text { Abs }(\text { Announcement } \\
\text { return }(1,5))\end{array}$ & & $\begin{array}{c}0.000 * * * \\
(6.56)\end{array}$ & & $\begin{array}{l}0.000 * * * \\
(6.58)\end{array}$ & & $\begin{array}{c}0.000 * * * \\
(6.56)\end{array}$ & & $\begin{array}{l}0.000 * * * \\
(6.57)\end{array}$ \\
\hline CEO duality & & $\begin{array}{l}0.001 \\
(0.56)\end{array}$ & & $\begin{array}{l}0.001 \\
(0.47)\end{array}$ & & $\begin{array}{l}0.001 \\
(0.56)\end{array}$ & & $\begin{array}{l}0.001 \\
(0.54)\end{array}$ \\
\hline $\begin{array}{l}\text { Board } \\
\text { independence }\end{array}$ & & $\begin{array}{c}-0.010 * * * \\
(-5.76)\end{array}$ & & $\begin{array}{c}-0.010 * * * \\
(-5.86)\end{array}$ & & $\begin{array}{c}-0.010 * * * \\
(-5.73)\end{array}$ & & $\begin{array}{c}-0.010 * * * \\
(-5.77)\end{array}$ \\
\hline Observations & 815,920 & 810,757 & 815,920 & 810,757 & 815,920 & 810,757 & 815,920 & 810,757 \\
\hline
\end{tabular}




\section{Table 11: Effects of political connections on insider trading behavior: Missing reporting requirement.}

This table presents the results from logit regressions of insider trading behavior. The dependent variable equals 1 if the a trade is reported after the $10^{\text {th }}$ day of the next calendar before August 2002 or after 2 trading days after August 2002; and equals 0 otherwise. $P I_{\text {combined }}$ is the sum of political index for the insider and the firm. The index calculations are explained in Section 3.2. Buy is equal one if the insider buys the stock and zero otherwise. Sell is equal one is the insider sells the stock and zero otherwise. $I M R_{\text {firm }}$ and $I M R_{\text {insider }}$ are the inverse Mills ratio calculated from Heckman's (1979) selection model. The results of the model's first stages are reported in Appendices C and D. Political indices are then standardized. The remaining variables are defined in Appendix A. t-statistics are in the brackets. ${ }^{* *}, * *$, and $*$ indicate significance at the $1 \%, 5 \%$ and $10 \%$ levels, respectively. 
Table 11: Effects of political connections on insider trading behavior: Missing reporting requirement (continued)

\begin{tabular}{|c|c|c|c|c|c|c|c|c|}
\hline \multicolumn{9}{|l|}{ Panel A: Coefficients } \\
\hline & \multicolumn{2}{|c|}{$\mathrm{PI}^{\text {candidates }}$} & \multicolumn{2}{|c|}{$\mathrm{PI}^{\text {strength }}$} & \multicolumn{2}{|c|}{ PI power } & \multicolumn{2}{|c|}{$\mathrm{PI}^{\text {relate }}$} \\
\hline & (1) & (2) & (3) & (4) & (5) & (6) & (7) & (8) \\
\hline $\mathrm{PI}_{\text {combined }} *$ Buy & $\begin{array}{c}0.068 * * * \\
(11.40)\end{array}$ & $\begin{array}{c}0.017 * * * \\
(3.01)\end{array}$ & $\begin{array}{c}0.042 * * * \\
(7.03)\end{array}$ & $\begin{array}{c}0.012 * * \\
(2.53)\end{array}$ & $\begin{array}{c}0.070 * * * \\
(11.75)\end{array}$ & $\begin{array}{c}0.016 * * * \\
(3.55)\end{array}$ & $\begin{array}{c}0.072 * * * \\
(12.04)\end{array}$ & $\begin{array}{c}0.014 * * * \\
(3.79)\end{array}$ \\
\hline $\mathrm{PI}_{\text {combined }} *$ Sell & $\begin{array}{c}0.116^{* * *} \\
(25.15)\end{array}$ & $\begin{array}{c}0.058 * * * \\
(10.49)\end{array}$ & $\begin{array}{c}0.129 * * * \\
(22.49)\end{array}$ & $\begin{array}{c}0.048 * * * \\
(9.64)\end{array}$ & $\begin{array}{c}0.124 * * * \\
(27.91)\end{array}$ & $\begin{array}{c}0.074 * * * \\
(12.44)\end{array}$ & $\begin{array}{c}0.126 * * * \\
(27.39)\end{array}$ & $\begin{array}{c}0.067 * * * \\
(11.37)\end{array}$ \\
\hline Buy & $\begin{array}{c}-0.978 * * * \\
(-188.83)\end{array}$ & $\begin{array}{c}-0.228 * * * \\
(-18.64)\end{array}$ & $\begin{array}{c}-0.978 * * * \\
(-188.95)\end{array}$ & $\begin{array}{c}-0.239 * * * \\
(-19.72)\end{array}$ & $\begin{array}{c}-0.978 * * * \\
(-188.73)\end{array}$ & $\begin{array}{c}-0.222 * * * \\
(-18.06)\end{array}$ & $\begin{array}{c}-0.982 * * * \\
(-188.73)\end{array}$ & $\begin{array}{c}-0.227 * * * \\
(-18.49)\end{array}$ \\
\hline Sell & $\begin{array}{c}-1.374 * * * \\
(-274.66)\end{array}$ & $\begin{array}{c}-0.412 * * * \\
(-29.22)\end{array}$ & $\begin{array}{c}-1.377 * * * \\
(-275.36)\end{array}$ & $\begin{array}{c}-0.424 * * * \\
(-30.31)\end{array}$ & $\begin{array}{c}-1.373 * * * \\
(-274.44)\end{array}$ & $\begin{array}{c}-0.408 * * * \\
(-28.78)\end{array}$ & $\begin{array}{c}-1.373 * * * \\
(-274.50)\end{array}$ & $\begin{array}{c}-0.413 * * * \\
(-29.18)\end{array}$ \\
\hline $\mathrm{IMR}_{\text {firm }}$ & $\begin{array}{c}0.036 * * * \\
(15.48)\end{array}$ & $\begin{array}{c}-0.031 * * * \\
(-13.01)\end{array}$ & $\begin{array}{c}0.038 * * * \\
(16.24)\end{array}$ & $\begin{array}{c}-0.031 * * * \\
(-12.99)\end{array}$ & $\begin{array}{c}0.035^{* * *} \\
(15.14)\end{array}$ & $\begin{array}{c}-0.031 * * * \\
(-13.03)\end{array}$ & $\begin{array}{c}0.035 * * * \\
(15.13)\end{array}$ & $\begin{array}{c}-0.031 * * * \\
(-13.00)\end{array}$ \\
\hline $\mathrm{IMR}_{\text {insider }}$ & $\begin{array}{c}-0.693 * * * \\
(-11.51)\end{array}$ & $\begin{array}{c}-0.604 * * * \\
(-19.63)\end{array}$ & $\begin{array}{c}-0.693 * * * \\
(-11.49)\end{array}$ & $\begin{array}{c}-0.604 * * * \\
(-19.65)\end{array}$ & $\begin{array}{c}-0.692 * * * \\
(-11.31)\end{array}$ & $\begin{array}{c}-0.604 * * * \\
(-19.64)\end{array}$ & $\begin{array}{c}-0.692 * * * \\
(-11.32)\end{array}$ & $\begin{array}{c}-0.604 * * * \\
(-19.64)\end{array}$ \\
\hline $\operatorname{Ln}(\operatorname{Size})$ & & $\begin{array}{c}-0.126 * * * \\
(-8.44)\end{array}$ & & $\begin{array}{c}-0.124 * * * \\
(-8.09)\end{array}$ & & $\begin{array}{c}-0.126 * * * \\
(-8.51)\end{array}$ & & $\begin{array}{c}-0.126 * * * \\
(-8.28)\end{array}$ \\
\hline $\begin{array}{l}\text { Institutional } \\
\text { ownership }\end{array}$ & & $\begin{array}{c}-0.236 * * * \\
(-4.30)\end{array}$ & & $\begin{array}{c}-0.236 * * * \\
(-4.23)\end{array}$ & & $\begin{array}{c}-0.237 * * * \\
(-4.37)\end{array}$ & & $\begin{array}{c}-0.237 * * * \\
(-4.37)\end{array}$ \\
\hline $\begin{array}{l}\text { Abs(Announcement } \\
\text { return }(1,5))\end{array}$ & & $\begin{array}{c}0.005 * * * \\
(12.36)\end{array}$ & & $\begin{array}{c}0.005 * * * \\
(12.32)\end{array}$ & & $\begin{array}{c}0.005 * * * \\
(12.32)\end{array}$ & & $\begin{array}{c}0.005 * * * \\
(12.33)\end{array}$ \\
\hline CEO duality & & $\begin{array}{c}0.101 * * * \\
(11.46)\end{array}$ & & $\begin{array}{c}0.102 * * * \\
(11.52)\end{array}$ & & $\begin{array}{c}0.102 * * * \\
(11.51)\end{array}$ & & $\begin{array}{c}0.102 * * * \\
(11.52)\end{array}$ \\
\hline $\begin{array}{l}\text { Board } \\
\text { independence }\end{array}$ & & $\begin{array}{c}-0.180 * * * \\
(-13.05)\end{array}$ & & $\begin{array}{c}-0.175 * * * \\
(-12.71)\end{array}$ & & $\begin{array}{c}-0.181 * * * \\
(-13.12)\end{array}$ & & $\begin{array}{c}-0.179 * * * \\
(-12.98)\end{array}$ \\
\hline Observations & 815,920 & 810,757 & 815,920 & 810,757 & 815,920 & 810,757 & 815,920 & 810,757 \\
\hline
\end{tabular}


Table 11: Effects of political connections on insider trading behavior: Missing reporting requirement (continued)

\begin{tabular}{|c|c|c|c|c|c|c|c|c|}
\hline \multicolumn{9}{|c|}{ Panel B: Marginal effects } \\
\hline & \multicolumn{2}{|c|}{$\mathrm{PI}^{\text {candidates }}$} & \multicolumn{2}{|c|}{$\mathrm{PI}^{\text {strength }}$} & \multicolumn{2}{|c|}{ PI power } & \multicolumn{2}{|c|}{ PI relate } \\
\hline & (1) & (2) & (3) & (4) & (5) & (6) & (7) & (8) \\
\hline $\mathrm{PI}_{\text {combined }} *$ Buy & $\begin{array}{c}0.011 * * * \\
(11.40)\end{array}$ & $\begin{array}{c}0.002 * * * \\
(3.01)\end{array}$ & $\begin{array}{c}0.007 * * * \\
(7.03)\end{array}$ & $\begin{array}{c}0.002 * * \\
(2.53)\end{array}$ & $\begin{array}{c}0.011 * * * \\
(11.75)\end{array}$ & $\begin{array}{c}0.002 * * * \\
(3.55)\end{array}$ & $\begin{array}{c}0.012 * * * \\
(12.04)\end{array}$ & $\begin{array}{c}0.002 * * * \\
(3.79)\end{array}$ \\
\hline $\mathrm{PI}_{\text {combined }} *$ Sell & $\begin{array}{c}0.019 * * * \\
(25.21)\end{array}$ & $\begin{array}{c}0.009 * * * \\
(10.49)\end{array}$ & $\begin{array}{c}0.021 * * * \\
(22.55)\end{array}$ & $\begin{array}{c}0.008 * * * \\
(9.64)\end{array}$ & $\begin{array}{c}0.020 * * * \\
(27.99)\end{array}$ & $\begin{array}{c}0.012 * * * \\
(12.45)\end{array}$ & $\begin{array}{c}0.020 * * * \\
(27.47)\end{array}$ & $\begin{array}{c}0.010 * * * \\
(11.37)\end{array}$ \\
\hline Buy & $\begin{array}{l}-0.150 * * * \\
(-218.20)\end{array}$ & $\begin{array}{c}-0.035 * * * \\
(-18.94)\end{array}$ & $\begin{array}{c}-0.150 * * * \\
(-218.29)\end{array}$ & $\begin{array}{c}-0.037 * * * \\
(-20.06)\end{array}$ & $\begin{array}{c}-0.150 * * * \\
(-218.00)\end{array}$ & $\begin{array}{c}-0.035 * * * \\
(-18.35)\end{array}$ & $\begin{array}{c}-0.150 * * * \\
(-218.04)\end{array}$ & $\begin{array}{c}-0.035 * * * \\
(-18.79)\end{array}$ \\
\hline Sell & $\begin{array}{c}-0.240 * * * \\
(-302.78)\end{array}$ & $\begin{array}{c}-0.067 * * * \\
(-28.59)\end{array}$ & $\begin{array}{c}-0.241 * * * \\
(-303.76)\end{array}$ & $\begin{array}{c}-0.069 * * * \\
(-29.65)\end{array}$ & $\begin{array}{c}-0.240 * * * \\
(-302.55)\end{array}$ & $\begin{array}{c}-0.066 * * * \\
(-28.17)\end{array}$ & $\begin{array}{c}-0.240 * * * \\
(-302.62)\end{array}$ & $\begin{array}{c}-0.067 * * * \\
(-28.55)\end{array}$ \\
\hline $\mathrm{IMR}_{\text {firm }}$ & $\begin{array}{c}0.006 * * * \\
(15.49)\end{array}$ & $\begin{array}{c}-0.005 * * * \\
(-13.01)\end{array}$ & $\begin{array}{c}0.006 * * * \\
(16.24)\end{array}$ & $\begin{array}{c}-0.005 * * * \\
(-12.99)\end{array}$ & $\begin{array}{c}0.006 * * * \\
(15.14)\end{array}$ & $\begin{array}{c}-0.005 * * * \\
(-13.03)\end{array}$ & $\begin{array}{c}0.006 * * * \\
(15.13)\end{array}$ & $\begin{array}{c}-0.005 * * * \\
(-13.01)\end{array}$ \\
\hline IMR $_{\text {insider }}$ & $\begin{array}{c}-0.113 * * * \\
(-11.95)\end{array}$ & $\begin{array}{c}-0.095 * * * \\
(-19.87)\end{array}$ & $\begin{array}{c}-0.113 * * * \\
(-11.93)\end{array}$ & $\begin{array}{c}-0.095 * * * \\
(-19.88)\end{array}$ & $\begin{array}{c}-0.112 * * * \\
(-11.73)\end{array}$ & $\begin{array}{c}-0.095 * * * \\
(-19.87)\end{array}$ & $\begin{array}{c}-0.112 * * * \\
(-11.74)\end{array}$ & $\begin{array}{c}-0.095 * * * \\
(-19.88)\end{array}$ \\
\hline $\operatorname{Ln}($ Size $)$ & & $\begin{array}{c}-0.020 * * * \\
(-8.62)\end{array}$ & & $\begin{array}{c}-0.020 * * * \\
(-8.27)\end{array}$ & & $\begin{array}{c}-0.020 * * * \\
(-8.69)\end{array}$ & & $\begin{array}{c}-0.020 * * * \\
(-8.46)\end{array}$ \\
\hline $\begin{array}{l}\text { Institutional } \\
\text { ownership }\end{array}$ & & $\begin{array}{c}-0.037 * * * \\
(-4.32)\end{array}$ & & $\begin{array}{c}-0.037 * * * \\
(-4.25)\end{array}$ & & $\begin{array}{c}-0.037 * * * \\
(-4.39)\end{array}$ & & $\begin{array}{c}-0.037 * * * \\
(-4.39)\end{array}$ \\
\hline $\begin{array}{l}\operatorname{Abs}(\text { Announcement } \\
\text { return }(1,5))\end{array}$ & & $\begin{array}{c}0.001 * * * \\
(12.37)\end{array}$ & & $\begin{array}{c}0.001 * * * \\
(12.32)\end{array}$ & & $\begin{array}{c}0.001 * * * \\
(12.32)\end{array}$ & & $\begin{array}{c}0.001 * * * \\
(12.33)\end{array}$ \\
\hline CEO duality & & $\begin{array}{c}0.016 * * * \\
(11.55)\end{array}$ & & $\begin{array}{c}0.016 * * * \\
(11.60)\end{array}$ & & $\begin{array}{c}0.016 * * * \\
(11.59)\end{array}$ & & $\begin{array}{c}0.016 * * * \\
(11.60)\end{array}$ \\
\hline $\begin{array}{l}\text { Board } \\
\text { independence }\end{array}$ & & $\begin{array}{c}-0.028 * * * \\
(-13.06)\end{array}$ & & $\begin{array}{c}-0.028 * * * \\
(-12.72)\end{array}$ & & $\begin{array}{c}-0.029 * * * \\
(-13.13)\end{array}$ & & $\begin{array}{c}-0.028 * * * \\
(-12.99)\end{array}$ \\
\hline Observations & 815,920 & 810,757 & 815,920 & 810,757 & 815,920 & 810,757 & 815,920 & 810,757 \\
\hline
\end{tabular}

